\title{
Flora fanerogâmica da Serra do Ouro Branco, Minas Gerais, Brasil: Cyperaceae
}

\author{
Phanerogamic flora from Serra do Ouro Branco, Minas Gerais, Brazil: Cyperaceae
}

Hilda Maria Longhi-Wagner ${ }^{1,3}$ \& Ana Claudia Araújo ${ }^{2}$

\begin{abstract}
Resumo
Foi realizado o levantamento das espécies de Cyperaceae na Serra do Ouro Branco da Cadeia do Espinhaço, no estado de Minas Gerais, Brasil, com base em coletas realizadas no local e revisão de herbários. Foi confirmada a ocorrência dos seguintes gêneros por ordem de riqueza específica: Rhynchospora (20 espécies), Bulbostylis (11), Eleocharis e Scleria (três espécies cada), Cyperus e Lagenocarpus (duas espécies cada), Cryptangium, Fimbristylis, Lipocarpha, Machaerina e Trilepis (uma espécie cada), totalizando 46 espécies. Este trabalho apresenta chaves para a identificação dos gêneros e espécies, descrições e ilustrações das mesmas, além de dados sobre sua distribuição geográfica geral e habitats preferenciais na área estudada, bem como um glossário da terminologia morfológica usada em Cyperaceae.
\end{abstract}

Palavras-chave: campo rupestre, diversidade, conservação, Cadeia do Espinhaço, taxonomia.

\begin{abstract}
A floristic survey of Cyperaceae species in the Serra of Ouro Branco from Espinhaço Range, Minas Gerais State, Brazil, was carried out, based on field collections and herbaria survey. The following genera were confirmed according to their species richness: Rhynchospora (20 species), Bulbostylis (11), Eleocharis e Scleria (three species each), Cyperus and Lagenocarpus (two species each), Cryptangium, Fimbristylis, Lipocarpha, Machaerina and Trilepis (one species each), an overall of 46 species. Analytical keys for the identification of genera and species, descriptions and illustrations of the species, data on their geographical distribution and main habitats in the area are provided, as well as a glossary of morphological terminology used in the Cyperaceae .
\end{abstract}

Key words: campo rupestre, diversity, conservation, Espinhaço range, taxonomy.

\section{Introdução}

A família Cyperaceae inclui ca. 109 gêneros e aproximadamente 5500 espécies, das quais grande parte apresenta distribuição cosmopolita (Govaerts et al. 2007). Alves et al. (2013) reconheceram 42 gêneros e 678 espécies no Brasil, sendo 203 endêmicas.

Estudos em Cyperaceae no Brasil datam do século XIX quando Nees (1842) publicou 314 espécies em 65 gêneros na Flora brasiliensis. Santa Catarina ainda é, até o momento, o único estado que apresenta um estudo taxonômico completo para a família (Barros 1960). Atualmente, dados sobre gêneros e espécies desta família para o Brasil podem ser verificados em Alves et al. (2013).
A Serra do Ouro Branco (SOB) representa o limite sul da Cadeia do Espinhaço, conjunto serrano que se estende por $1.100 \mathrm{~km}$ de Minas Gerais até a Bahia, na região da Chapada Diamantina (Meguro et al. 1994). Assim como nas demais serras do Espinhaço, a SOB apresenta o campo rupestre como tipo de vegetação dominante, acima de 900 m, aqui definido de acordo com Magalhães (1966). Entremeados às áreas de campos graminosos, encontram-se afloramentos rochosos e capões de mata. Além disto, campos brejosos são encontrados nas baixadas e matas de galeria de pequena extensão ao longo dos cursos d'água (Paula et al. 2005).

O conhecimento de Cyperaceae para a Cadeia do Espinhaço, em geral, se restringe à citação

\footnotetext{
${ }^{1}$ Universidade Federal do Rio Grande do Sul, PPG Botânica, Av. Bento Gonçalves 9500, bl. IV, prédio 43435, 91501-970, Porto Alegre, RS, Brasil.

${ }^{2}$ Royal Botanic Gardens, Kew, Herbarium, Kew Gardens, Richmond TW9 3AE, Richmond, Inglaterra.

${ }^{3}$ Autor para correspondência: hmlwagner@gmail.com
} 
de espécies em listagens florísticas que incluem diferentes famílias, como 24 espécies para Mucugê (Harley \& Simmons 1986), 48 para o Pico das Almas (Simpson 1995) e 25 para Catolés (Zappi et al. 2003), na Chapada Diamantina, além de 32 para a Serra do Cipó, no Espinhaço Central, em Minas Gerais (Mayo 1987), e 10 na Serra da Calçada, no sul da Cadeia do Espinhaço, Minas Gerais (Viana \& Lombardi 2007). Para a Serra de Grão Mogol, Vitta \& Prata (2009) estimaram a ocorrência de 34 espécies e dez gêneros. Mais recentemente, Borges et al. (2011) incluíram, na listagem de plantas vasculares das Serras do Ouro Branco e Serra do Ribeiro (município de Ouro Preto), dez espécies de Cyperaceae para a primeira, acrescidas de mais três espécies para a segunda.

O presente trabalho faz parte do projeto "Flora fanerogâmica da Serra do Ouro Branco" coordenado pelo pesquisador Cláudio Coelho de Paula, da Universidade Federal de Viçosa. A riqueza específica de Cyperaceae da referida Serra foi analisada e os resultados estão apresentados de forma a permitir a identificação das espécies confirmadas. Para isto são fornecidas chaves para a identificação de gêneros e espécies, descrições e ilustrações. Além disto, são fornecidos dados de distribuição geográfica geral e dos ambientes de ocorrência das espécies na área estudada, bem como um glossário de terminologia morfológica visando facilitar a utilização das chaves e interpretação das descrições.

\section{Material e Métodos}

A Serra do Ouro Branco (SOB) está localizada no sul da Cadeia do Espinhaço, município de Ouro Branco, no Estado de Minas Gerais $\left(20^{\circ} 29^{\prime} \mathrm{S}\right.$, $\left.43^{\circ} 43^{\prime} \mathrm{W}\right)$. A SOB apresenta, aproximadamente, uma área de 2750 ha, com ca. $20 \mathrm{~km}$ de extensão e altitudes entre 900 e 1568 m.s.m. O clima predominante na região é $\mathrm{Cwb}$, segundo a classificação de Köppen, com temperatura média anual de $20,7^{\circ} \mathrm{C}$ e precipitação média anual de $1188,2 \mathrm{~mm}$. Os solos são predominantemente de origem quartzítica, com poucos encraves de solos argilosos e ferruginosos (Paula et al. 2005). O mapa da área está disponível em Santos \& Sano (2012).

Foram realizadas coletas na SOB ao longo do período de junho de 2002 a dezembro de 2007, nas diferentes estações do ano, principalmente pela equipe do coordenador do projeto, além de três viagens de coleta realizadas pelas autoras, em março de 2005, janeiro de 2006 e dezembro de 2007. Os exemplares foram depositados no herbário VIC e duplicatas, quando disponíveis, nos herbários ICN e K. Foram revisados também materiais coletados na Serra do Ouro Branco, depositados nos herbários BHCB, OUPR, R, RB e SPF (acrônimos conforme Thiers continuously updated).

As espécies aqui citadas foram aceitas seguindo World Checklist of Selected Plants Families (WCSP 2013), em concordância com o proposto por Alves et al. (2013). Nos casos de discordância, seguiu-se preferencialmente Alves et al. (2013) para gêneros revisados por especialistas brasileiros (ex.: Lagenocarpus e Cryptangium) e, para aqueles não revisados, seguiu-se preferencialmente WCSP (2013).

A distribuição geográfica dos táxons foi compilada, preferencialmente, a partir de dados disponíveis em revisões taxonômicas e em outros trabalhos citados diretamente no texto, para permitir um maior detalhamento, foram ajustados de acordo com Alves et al. (2013) e atualizados com base no banco de dados das autoras.

A descrição da família foi feita com base na literatura (Goetghbeur 1998; Heywood et al. 2007). As descrições dos gêneros foram feitas com base na literatura utilizando-se, preferencialmente, trabalhos publicados para o Brasil ou América do Sul, os quais são citados no final da descrição de cada gênero. Estas descrições foram ajustadas para incluir a variação morfológica encontrada na SOB, para auxiliar na identificação das espécies. A chave para gêneros exclui as variações não encontradas nas espécies da SOB, para facilitar a sua utilização. Por outro lado, as descrições das espécies foram feitas com base no material coletado na SOB e, quando necessário, em exemplares de outras localidades para complementar as descrições, exemplares estes citados como material adicional examinado.

Os dados de habitat das espécies encontradas na SOB foram obtidos a partir da observação das populações no campo e das informações contidas nas etiquetas das exsicatas. As medidas de dimensão do fruto não incluem o estilopódio. A terminologia para os diferentes habitats encontrados na SOB segue Paula et al. (2005), com pequenas modificações. Deste modo, estão sendo utilizados: campos graminosos (quartzíticos, em sua maioria, ou areníticos, argilosos e ferruginosos, em áreas menores); campos brejosos; afloramentos rochosos; matas de galeria/capões de mata; ambientes ruderais. 
O glossário (Anexo) foi elaborado com base em literatura especializada (Goetghebeur 1998; Beentje 2010) e ampliado com o resultado do estudo minucioso de material de herbário de diversos gêneros e espécies de Cyperaceae da flora brasileira feitos previamente pela segunda autora.

\section{Resultados e Discussão}

Cyperaceae está representada na SOB por 46 espécies distribuídas em 11 gêneros, dos quais Rhynchospora, com um total de 20 espécies, é o gênero mais bem representado, seguido de Bulbostylis, com 11 espécies. Convém salientar que Rhynchospora é o gênero de Cyperaceae com maior número de espécies no Brasil (140 espécies, Alves et al. 2013) e apresenta espécies características de campos rupestres/cerrado e espécies de áreas brejosas, ocupando, portanto, habitats diversificados dos campos rupestres. Deste modo, não surpreende a sua maior representatividade na SOB. Os demais nove gêneros estão representados por uma até três espécies. As espécies confirmadas para Rhynchospora ocorrem comumente em solos secos, sendo bastante comuns em afloramentos rochosos. Por outro lado, espécies relacionadas à $R$. tenuis Link e R. rugosa (Vahl) Gale foram encontradas em ambientes úmidos. As espécies de Bulbostylis ocorrem geralmente no campo rupestre, associadas aos solos arenosos quartzíticos. Em áreas úmidas e brejosas, pouco comuns na área de estudo, ocorre a colonização por espécies de Eleocharis, Lipocarpha e Machaerina, como é característico para estes gêneros. Por sua vez, Cyperus apresenta uma espécie ruderal na área e uma espécie de brejo, também refletindo uma condição ecológica característica do gênero. $\mathrm{O}$ ambiente predominantemente rupestre e com clima seco na maior parte do ano pode explicar o baixo número de espécies de Cyperus e de Eleocharis que são, respectivamente, o segundo e o quarto gênero mais diverso de Cyperaceae em número de espécies, no Brasil (Alves et al. 2013).

Com base nos dados de Alves et al. (2013) todas as 46 espécies encontradas na SOB são nativas do Brasil, das quais 10 são referidas como endêmicas (Alves et al. 2013). Entretanto, apenas seis destas 10 foram confirmadas como endêmicas no presente trabalho, uma vez que Bulbostylis fasciculata Uitten, B. sphaerocephala (Boeck.) Lindm., Rhynchospora velutina (Kunth) Boeck. e $R$. warmingii Boeck. apresentam distribuição mais ampla do que o território brasileiro. Por outro lado, Rhynchospora lapensis é endêmica do Brasil (dados das autoras) mas não foi citada como tal por Alves et al. (2013).

Uma comparação entre a composição de Cyperaceae da SOB com estudos florísticos publicados para outras áreas de campo rupestre da Cadeia do Espinhaço (Harley \& Simmons 1986; Mayo 1987; Simpson 1995; Zappi et al. 2003; Viana \& Lombardi 2007; Vitta \& Prata 2009) deve levar em conta as diferenças no tamanho das áreas amostradas e no esforço amostral, bem como os diferentes microhabitats existentes no campo rupestre. Estes fatores poderiam explicar a grande discrepância entre o número de espécies encontradas na SOB (o maior número de espécies entre os trabalhos de florística aqui citados) e o total de dez espécies (o menor entre os trabalhos acima citados) na Serra da Calçada (Viana \& Lombardi 2007). Neste último foram amostrados pouco mais de $5 \mathrm{~km}^{2}$ de campo rupestre com solos do tipo canga, enquanto na SOB foram amostrados ca. de $27,5 \mathrm{~km}^{2}$ de campo rupestre em diversos ambientes embora, predominantemente, com solos de origem quartzítica. Em princípio, a riqueza específica de Cyperaceae na SOB (46 espécies), localizada no extremo sul da Cadeia do Espinhaço (Minas Gerais), é semelhante à da flora do Pico das Almas (45 espécies, Zappi et al. 2003), situado no norte da Cadeia do Espinhaço (Chapada Diamantina, Bahia). No entanto, a família Cyperaceae na SOB é, proporcionalmente, mais diversificada levando-se em conta a área amostrada no Pico das Almas (170 $\mathrm{km}^{2}$ ). De acordo com Harley (1995), enquanto a precipitação pluviométrica anual é de $1500 \mathrm{~mm}$ na Cadeia do Espinhaço em Minas Gerais, os registros para a Chapada Diamantina mostram números bem mais baixos, semelhantes às áreas de baixa altitude circundantes. Isto explicaria a maior diversidade ciperológica na $\mathrm{SOB}$, principalmente no número de gêneros (11, contra oito no Pico das Almas), com a presença de gêneros higrófilos/hidrófilos como Machaerina e Lipocarpha, ausentes no Pico das Almas (e também em Catolés e Mucugê, na Chapada Diamantina). Já o gênero Lagenocarpus, cujas espécies são, geralmente, associadas às áreas mais secas dos campos rupestres, inclusive afloramentos rochosos, apresenta sete espécies no Pico das Almas e apenas duas na SOB. Por outro lado, o gênero Eleocharis, comum em ambientes úmidos semelhantes à ocorrência de Machaerina e Lipocarpha, apresenta sete espécies no Pico das Almas e apenas três na SOB o que poderia estar 
relacionado com o tamanho da área amostrada. Análises mais detalhadas de dados ecológicos versus florísticos são necessárias para testar estas hipóteses.

Considerando aspectos da conservação das espécies de Cyperaceae encontradas na SOB, chama-se a atenção que somente Rhynchospora warmingii encontra-se entre as cinco espécies desta família incluídas na Lista Oficial de Espécies da Flora Brasileira Ameaçadas de Extinção (MMA 2013), citada apenas para a Caatinga, no estado da Bahia. Entretanto, a coleta e a observação de populações bem estabelecidas desta espécie na SOB permitem sugerir uma reavaliação de seu status de conservação, conforme salientado abaixo, nos comentários sobre esta espécie. Além disto, das 15 espécies de Cyperaceae incluídas na Lista Vermelha da Flora Ameaçada de Minas Gerais (Fundação Biodiversitas 2001) apenas Bulbostylis tenuifolia (status VU) foi encontrada na SOB, representada somente por uma pequena população. Salienta-se que nenhuma das espécies de Cyperaceae da SOB é rara na flora brasileira, levando em conta os dados apresentados por Giulietti et al. (2009).

\section{Descrição da família}

Ervas anuais ou perenes, cespitosas, rizomatosas ou não, menos comumente estoloníferas ou, em raros casos, desenvolvendo um caudex.
Colmos triangulares ou subtriangulares, cilíndricos, menos comumente 4-5-6-angulares, mais raramente lenticulares. Folhas sésseis basilares ou alternotrísticas, menos comumente dísticas, às vezes com lâminas reduzidas ou até inconspícuas; bainhas fechadas, muito raramente abertas; lâminas lineares ou lanceoladas, planas, conduplicadas, convolutas, cilíndricas ou subcilíndricas. Inflorescência terminal ou axilar, em espiga, fascículo, capítulo, paniculódio ou antelódio, ou combinação destes, ou ainda uma única espigueta no ápice do colmo (ex.: Eleocharis); brácteas involucrais presentes ou não, se presentes, foliáceas ou glumiformes, rosuladas na base da inflorescência, ou apenas uma na base de inflorescências laterais. Espiguetas sésseis, subsésseis ou pediceladas, unissexuadas ou bissexuadas, glumas dísticas ou espiraladamente dispostas sobre a ráquila, menos comumente subdísticas. Flores unissexuadas ou bissexuadas; perigônio reduzido, em forma de cerdas perigoniais, escamas hipóginas ou hipogínio cupuliforme (ex. Scleria) ou ainda, ausente; androceu com (1)2-3(12) estames; gineceu (1)2-3-carpelar, unilocular, uniseminado. Aquênio lenticular, biconvexo, triangular ou globoso, branco, castanho, vináceo ou negro, estipitado ou não na base, às vezes envolto em um utrículo; estilopódio presente ou não no ápice do fruto. (adaptada de Goetghbeur 1998; Heywood et al. 2007).

\section{Chave para os gêneros de Cyperaceae da Serra do Ouro Branco}

1. Espigueta única no ápice do colmo. Folhas reduzidas às bainhas, lâminas ausentes ...... 4. Eleocharis

1'. Espiguetas numerosas, em inflorescências variadas. Folhas com lâminas desenvolvidas (geralmente ausentes apenas em Cyperus haspan).

2. Flores bissexuadas. Folhas sem contralígula.

3. Espiguetas comprimidas lateralmente, com as glumas disticamente dispostas. Colmos triangulares. Lâminas foliares planas

3'. Espiguetas cilíndricas, com as glumas de disposição espiralada (menos comumente, espiguetas com glumas subdísticas em Bulbostylis p.p., então colmos cilíndricos e lâminas filiformes). Colmos triangulares ou cilíndricos, mais raramente achatados. Lâminas foliares planas, convolutas, conduplicadas, cilíndricas ou subcilíndricas.

4. Base do estilete persistente no ápice do fruto, formando um estilopódio com diferentes graus de desenvolvimento.

5. Estilopódio e aquênio alados ao longo dos ângulos

8. Machaerina

5'. Estilopódio e aquênio sem alas.

6. Estigmas 3-fidos. Estilopódio formando apenas um tubérculo no ápice do fruto ............................................................................ 1. Bulbostylis

6'. Estigmas 2-fidos ou indivisos. Estilopódio com formatos variados, geralmente triangular ou piramidal, nunca na forma de tubérculo ....... 9. Rhynchospora

4'. Base do estilete caduca com o restante do estilete, na maturação, não persistindo sobre o ápice do fruto, sem formar um estilopódio. 
7. Inflorescência do tipo antelódio, terminal. Espiguetas plurifloras

5. Fimbristylis

7'. Inflorescência do tipo espiga, uma terminal e 3-5 sésseis pseudolaterais. Espiguetas unifloras ...

2'. Flores unissexuadas. Folhas com contralígula.

7. Lipocarpha

8. Inflorescência com as espiguetas estaminadas e pistiladas dispostas ao longo de todos os ramos.

9. Espiguetas comprimidas lateralmente, as estaminadas basais e as pistiladas apicais em cada ramo. Aquênio oblongo, envolto por um utrículo oblongo-acuminado 11. Trilepis

9'. Espiguetas cilíndricas, as estaminadas apicais e as pistiladas basais em cada ramo. Aquênio globoso, não envolto por um utrículo 10. Scleria

8'. Inflorescência com as espiguetas estaminadas nos ramos floríferos basais, as pistiladas nos ramos floríferos apicais.

10. Fruto de secção transversal circular. Espiguetas estaminadas com glumas dísticas ou subdísticas. Folhas formando rosetas basais 6. Lagenocarpus

10'. Fruto de secção transversal trígona. Espiguetas estaminadas com glumas espiraladas. Folhas formando pseudoverticilos no ápice do colmo

2. Cryptangium

\section{Bulbostylis Kunth}

Plantas perenes ou anuais, com ou sem rizomas, raramente com caudex desenvolvido. Folhas basilares, com bainhas e lâminas desenvolvidas, lígula e contralígula ausentes; bainhas com o ápice ciliado, não hialino e não marcescente; lâminas filiformes, mais raramente planas. Colmos triangulares ou cilíndricos. Brácteas involucrais presentes. Inflorescência monocéfala ou do tipo antelódio simples com espiguetas isoladas no ápice dos ramos, não reunidas em fascículos, ou antelódio composto, com espiguetas agrupadas em fascículos. Espiguetas sésseis ou pediceladas, plurifloras, cilíndricas, glumas de disposição espiralada sobre a ráquila ou, menos comumente, espiguetas subcomprimidas lateralmente, glumas subdísticas. Flores bissexuadas, perigônio ausente; estames 1-3; estigmas 3-fidos, base do estilete não dilatada, persistente sobre o fruto, estilopódio não alado, formando um pequeno tubérculo no ápice do fruto. Aquênio com seção transversal trígona, não alado, não envolto por um utrículo, superfície lisa, transversalmente rugosa, tuberculada ou papilosa (adaptada de Kral 1971; Adams 1994a; Prata 2004).

Bulbostylis compreende 150 espécies que habitam solos arenosos, úmidos ou secos, distribuindo-se na América do Sul e África (Adams 1994a; Prata 2004). Está representado na SOB por 11 espécies.

\section{Chave para espécies de Bulbostylis da Serra do Ouro Branco}

1. Caudex desenvolvido; folhas prostradas. Inflorescência monocéfala 1.7. Bulbostylis paradoxa

1'. Caudex ausente, plantas cespitosas com rizoma curto ou desenvolvido; folhas eretas ou pendentes. Inflorescência em antelódio.

2. Espiguetas reunidas em capítulos.

3. Brácteas involucrais 6-8, a mais inferior $1,5-2(-3) \mathrm{cm}$ compr. Lâminas foliares escabras .... 1.8. Bulbostylis sphaerocephala

3'. Brácteas involucrais 2(-3), a mais inferior 1-1,2 cm compr. Lâminas foliares hirsutas 1.10. Bulbostylis vestita

2'. Espiguetas isoladas ou em fascículos laxos.

4. Antelódio composto, espiguetas agrupadas em fascículos no ápice dos ramos, fascículos com pelo menos cinco espiguetas cada um.

5. Espiguetas cilíndricas, 2-3 mm larg. Glumas espiraladas, elíptico-lanceoladas 1.2. Bulbostylis consanguinea

5'. Espiguetas subcomprimidas lateralmente, 0,7-1,5 $\mathrm{mm}$ larg. Glumas subdísticas, ovallanceoladas.

6. Bráctea involucral inferior mais curta do que o antelódio, ca. 1,5 cm compr. 
6'. Bráctea involucral inferior mais longa do que o antelódio, 2-2,5 cm compr.

\subsection{Bulbostylis junciformis}

4'. Antelódio simples, espiguetas isoladas no ápice dos ramos, não reunidas em fascículos.

7. Colmos cilíndricos. Aquênio papiloso.

8. Lâminas filiformes. Bráctea involucral inferior 2,5-3 cm compr., mais longa do que a inflorescência. Espiguetas 2,5-2,8 mm compr., glumas ovais, margens não hialinas 1.11. Bulbostylis sp.

8. Lâminas planas. Bráctea involucral inferior 1-2 cm compr., mais curta do que a inflorescência. Espiguetas 6-8 mm compr., glumas elíptico-lanceoladas, margens hialinas

1.4. Bulbostylis jacobinae

7'. Colmos triangulares. Aquênio transversalmente rugoso.

9. Plantas 30-55 cm alt.. Lâminas $12-20 \mathrm{~cm}$ compr. Antelódio 4-7cm compr. Espiguetas 5-6 mm compr., glumas pubescentes .............................................. 1.6. Bulbostylis juncoides

9'. Plantas 7-25 cm alt. Lâminas 4-7 cm compr. Antelódio 1-2 cm compr. Espiguetas 3-4 mm compr., glumas glabrescentes.

10. Estames 3. Bráctea involucral inferior mais longa do que a inflorescência, 1,5-2,5 cm compr. Aquênio 1-1,2 mm compr. .................................... 1.1. Bulbostylis capillaris

10'. Estame 1. Bráctea involucral inferior mais curta do que a inflorescência, $0,5-0,6 \mathrm{~cm}$ compr. Aquênio ca. $0,7 \mathrm{~mm}$ compr.

1.9. Bulbostylis tenuifolia

1.1. Bulbostylis capillaris (L.) C.B. Clarke in Hook. f., Fl. Brit. India 6: 652. $1893 . \quad$ Fig. 1a-c

Plantas 10-25 cm alt., perenes, cespitosas, com rizomas curtos. Folhas eretas, lâminas 5-7 $\mathrm{cm} \times 0,7-0,8 \mathrm{~mm}$, filiformes, glabras. Colmos triangulares, glabros. Brácteas involucrais 2-3, a inferior 1,5-2,5 cm compr., mais longa do que a inflorescência. Antelódio simples, 1-1,2 cm compr., espiguetas isoladas no ápice dos ramos. Espiguetas 3-4 × 1,5-2 mm, cilíndricas; glumas espiraladas, largamente ovais, margens não hialinas, glabrescentes, ápice agudo. Estames 3. Aquênio 1-1,2 × 0,7-0,8 mm, obovóide, superfície transversalmente rugosa.

Material examinado: $20^{\circ} 29^{\prime} 6,5^{\prime} \mathrm{S} 43^{\circ} 42^{\prime} 39,7^{\prime \prime} \mathrm{W}$, 8.I.2006, fl. e fr., H.M. Longhi-Wagner \& C.C. de Paula 9972 (ICN, VIC); 20³0’22”S 4337’59,3”'W, 2.XII.2007, fl., H.M. Longhi-Wagner et al. 10336 (ICN, VIC).

Bulbostylis capillaris ocorre nas Américas, em áreas tropicais e subtropicais. É amplamente distribuída no Brasil, sendo também, frequentemente, encontrada em ambiente ruderal e lavouras abandonadas (Prata 2004). Na SOB foi encontrada em campos brejosos com solos arenosoquartzíticos, a 1560 m.s.m.

1.2. Bulbostylis consanguinea (Kunth) C.B. Clarke, Kew Bull. Addit. Ser. 8: 110. 1908.

Fig. 1d-e

Plantas 50-75 cm alt., perenes, cespitosas, com rizomas curtos. Folhas eretas ou pendentes, lâminas (10-)20-25 cm × 0,5(-0,7) $\mathrm{mm}$, filiformes, glabras. Colmos triangulares, glabros. Brácteas involucrais 3-4, a inferior 2,5-3 cm compr., mais curta do que a inflorescência. Antelódio composto, ca. $5 \mathrm{~cm}$ compr., espiguetas 5-10 agrupadas em fascículos densos e sésseis. Espiguetas 3-4 $\times 2-3 \mathrm{~mm}$, cilíndricas; glumas espiraladas, elíptico-lanceoladas, margens hialinas, curtamente pubescentes, ápice mucronado. Estames 3. Aquênio ca. $1 \times 0,5 \mathrm{~mm}$, obovóide, superfície papilosa.

Material examinado: $20^{\circ} 30^{\prime} 1,9^{\prime \prime} \mathrm{S} 43^{\circ} 39^{\prime} 44,9^{\prime \prime} \mathrm{W}$, 10.I.2006, fl. e fr., H.M. Longhi-Wagner \& C.C. de Paula 10073 (ICN).

Bulbostylis consanguinea ocorre na América do Sul tropical e subtropical e está amplamente distribuída no Brasil, em vegetação aberta com solos arenosos, principalmente no cerrado (Prata 2004). Na SOB é pouco comum e foi encontrada em campos graminosos com solos argilosos, a 1360 m.s.m.

1.3. Bulbostylis fasciculata Uittien, Rec. Trav. Bot. Neerl. 22: 338. 1925.

Fig. 1f-g

Plantas $30-55 \mathrm{~cm}$ alt., perenes, cespitosas, com rizomas curtos. Folhas eretas, lâminas 10-20 $\mathrm{cm} \times 0,5-0,7 \mathrm{~mm}$, filiformes, glabras. Colmos cilíndricos, glabros. Brácteas involucrais 2, a inferior ca. 1,5 cm compr., mais curta do que a inflorescência. Antelódio composto, 1,5-2,6 cm compr., espiguetas 7-10 agrupadas em fascículos densos e sésseis. Espiguetas 3-3,5 × 0,7-1 mm, 


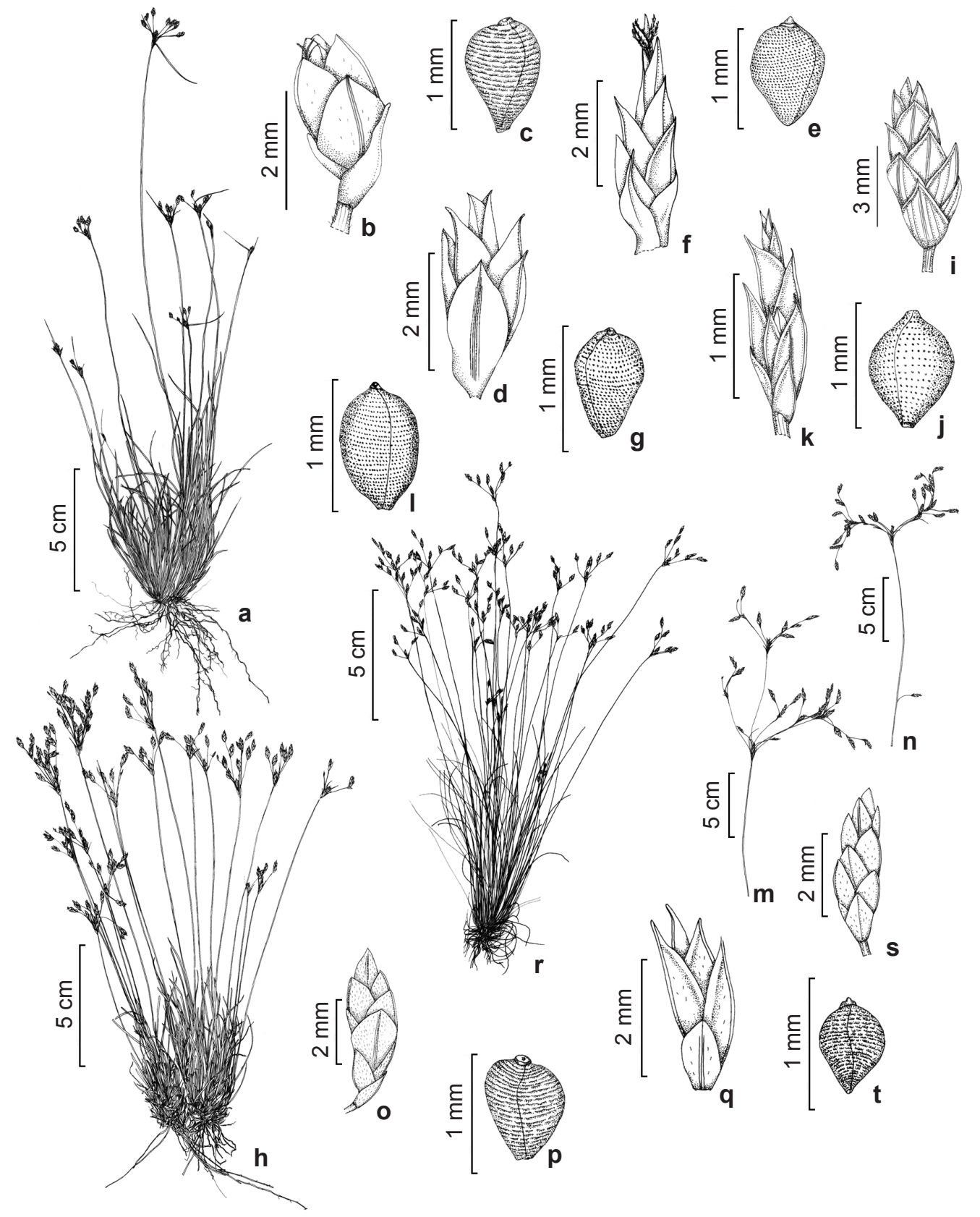

Figura 1 - a-c. Bulbostylis capillaris - a. hábito; b. espigueta; c. aquênio. d-e. B. consanguinea - d. espigueta; e. aquênio. f-g. B. fasciculata - f. espigueta; g. aquênio. h-j. B. jacobinae - h. hábito; i. espigueta; j. aquênio. k-1. $B$. junciformis - k. espigueta; 1. aquênio. m-p. $B$. juncoides - m-n. inflorescências; o. espigueta; p. aquênio. q. $B$. sphaerocephala - espigueta. r-t. B. tenuifolia - r. hábito; s. espigueta; t. aquênio (a-c H.M. Longhi-Wagner \& C.C. de Paula 9972; d-e H.M. Longhi-Wagner \& C.C. de Paula 10073; f-g H.M. Longhi-Wagner \& C.C. de Paula 10015; h-j H.M. Longhi-Wagner et al. 10393; k-1 H.M. Longhi-Wagner \& C.C. de Paula 10061; m-p H.M. Longhi-Wagner \& C.C. de Paula 10003; q H.M. Longhi-Wagner \& C.C. de Paula 10014; r-t H.M. Longhi-Wagner \& C.C. de Paula 9560). Figure 1 - a-c. Bulbostylis capillaris - a. habit; b. spikelet; c. achene. d-e. B. consanguínea - d. spikelet; e. achene. f-g. B. fasciculata - f. spikelet; g. achene. h-j. B. jacobinae - h. habit; i. spikelet; j. achene. k-1. B. junciformis - k. spikelet; 1. achene. m-p. B. juncoides m, n. inflorescences; o. spikelet; p. achene. q. B. sphaerocephala - spikelet. r-t. B. tenuifolia - r. habit; s. spikelet; t. achene (a-c H.M. Longhi-Wagner \& C.C. de Paula 9972; d-e H.M. Longhi-Wagner \& C.C. de Paula 10073; f-g H.M. Longhi-Wagner \& C.C. de Paula 10015; h-j H.M. Longhi-Wagner et al. 10393; k-1 H.M. Longhi-Wagner \& C.C. de Paula 10061; m-p H.M. Longhi-Wagner \& C.C. de Paula 10003; q H.M. Longhi-Wagner \& C.C. de Paula 10014; r-t H.M. Longhi-Wagner \& C.C. de Paula 9560). 
subcomprimidas lateralmente; glumas subdísticas, oval-lanceoladas, margens hialinas, glabras, ápice mucronado. Estames 3. Aquênio ca. $0,8 \times 0,5 \mathrm{~mm}$, obovóide, superfície papilosa.

Material examinado: 20.VIII.2007, fl., F.O.A. Lemes s.n. (ICN, OUPR 21445); 20³0'19,6”'S 43³7'56,8'W, 9.I.2006, fl., H.M. Longhi-Wagner \& C.C. de Paula 9986, 9992 (ICN, VIC); 20²9'6,1'S 4343'3,4”W, 9.I.2006, fl. e fr., H.M. Longhi-Wagner \& C.C. de Paula 10015 (ICN, VIC).

Bulbostylis fasciculata ocorre na América do Sul setentrional e está amplamente distribuída nas regiões tropicais do Brasil, em vegetação campestre com solos arenosos (Prata 2004). Na SOB foi encontrada junto a afloramentos rochosos, sobre solos arenoso-quartzíticos, entre 1270 e 1490 m.s.m.

1.4. Bulbostylis jacobinae (Steud.) Lindm., Bih. Kongl. Svenksa Vetensk.-Akad. Handl. 26(9): 18. 1901.

Fig. 1h-j

Plantas 15-28 cm alt., perenes, cespitosas, com rizomas curtos. Folhas eretas, lâminas 5-11 $\mathrm{cm} \times 0,6-0,8 \mathrm{~mm}$, planas, curtamente ciliadas nas margens. Colmos cilíndricos, glabros. Brácteas involucrais 2-3, a inferior 1-2 cm compr., mais curta do que a inflorescência. Antelódio simples, 3-5 cm compr., espiguetas isoladas no ápice dos ramos. Espiguetas 6-8 × 2-2,5(-3) mm, cilíndricas; glumas espiraladas, elíptico-lanceoladas, margens hialinas, glabras, ápice agudo. Estames 3. Aquênio 0,7-0,9× 0,5-0,6 mm, obovóide, superfície papilosa.

Material examinado: $20^{\circ} 29^{\prime} 14,4$ "S $43^{\circ} 41^{\prime} 15,6$ "W, 3.XII.2007, fl. e fr., H.M. Longhi-Wagner et al. 10393 (ICN, K, VIC); 20²8'52”'S 43॰43'40,9”'W, 4.XII.2007, fl., H.M. Longhi-Wagner et al. 10461 (ICN, VIC); 20²8'41,3"'S 4344'03'W, 4.XII.2007, fl., H.M. LonghiWagner et al. 10462 (ICN, K, VIC); 20³0'31,4”S 4347'10,4”W, 4.XII.2007, fl. e fr., H.M. Longhi-Wagner et al. 10498 (ICN, VIC).

Bulbostylis jacobinae foi registrada para o Paraguai (dados das autoras) e Brasil. Esta espécie está presente em todas as regiões do país, principalmente nas Regiões Nordeste, Centro-Oeste e Sudeste, sendo mais comum em cerrado e campo rupestre (Prata 2004). Na SOB foi encontrada em campos graminosos quartzíticos e em afloramentos rochosos, entre 1270 e 1420 m.s.m.

1.5. Bulbostylis junciformis (Kunth) C.B. Clarke, Trans. Linn. Soc. London, Bot. 4: 512. 1895.

Fig. $1 \mathrm{k}-1$

Plantas (35)45-60 cm alt., perenes, cespitosas, com rizomas curtos. Folhas eretas ou pendentes, lâminas $18-25 \mathrm{~cm} \times 0,5-0,6 \mathrm{~mm}$, filiformes, glabras. Colmos cilíndricos, glabros. Brácteas involucrais $1-3$, a inferior $2-2,5 \mathrm{~cm}$ compr., mais longa do que a inflorescência. Antelódio composto, $1-1,5 \mathrm{~cm}$ compr., espiguetas 10 ou mais agrupadas em fascículos densos, curtamente pedicelados. Espiguetas 3-3,5 × 1-1,5 mm, subcomprimidas lateralmente; glumas subdísticas, oval-lanceoladas, margens hialinas, glabras, ápice mucronado. Estames 3. Aquênio 0,8-1×0,5-0,6 mm, obovóide, superfície papilosa.

Material examinado: $20^{\circ} 30^{\prime} 18,9$ "S $43^{\circ} 36^{\prime} 28,6$ 'W, 8.V.2004, fl. e fr., R.A.X. Borges 111 (ICN, OUPR); 20³0'12,2'S 4340'18,8'W, 10.I.2006, fl., H.M. LonghiWagner \& C.C. de Paula 10061 (ICN); 20³0'22”'S 4337'59,3'W, 2.XII.2007, fl. e fr., H.M. LonghiWagner et al. 10329 (K); 20³0'19,4”S 4337'56,1'W, 2.XII.2007, fl., H.M. Longhi-Wagner et al. 10369 (ICN, K, VIC); 20³0'31,1'S 43॰36'54,4”W, 5.XII.2007, fl. e fr., H.M. Longhi-Wagner et al. 10508, 10511 (ICN, K). B. aff. junciformis: 20³0'20,4'’S 4337'55'”, 5.XII.2007, fl. e fr., H.M. Longhi-Wagner et al. 10482 (ICN, K).

Bulbostylis junciformis está distribuída desde o México até o Uruguai e Antilhas (Adams 1994a). Espécie amplamente distribuída em todas as regiões do Brasil, embora seja mais comum no cerrado (Prata 2004). Na SOB foi encontrada em campos graminosos quartzíticos, e em campo sujo próximo à mata de galeria, entre 1110 e 1350 m.s.m. O exemplar H.M. Longhi-Wagner et al. 10482 apresenta espiguetas reunidas em capítulos, pouco comum nesta espécie, e colmo quadrangular, contrariando o que foi observado na maioria dos espécimes estudados, os quais apresentam colmo cilíndrico. Revisando literatura especializada e coleções de Bulbostylis junciformis depositadas nos herbários analisados, optou-se por identificar este material como Bulbostylis aff. junciformis, salientando que esta variabilidade deve ser investigada para permitir uma correta identificação deste espécime.

1.6. Bulbostylis juncoides (Vahl) Kük. ex Herter, Estud. Bot. Reg. Uruguay 4: 40 (1931).

Fig. $1 \mathrm{~m}-\mathrm{p}$

Plantas 30-55 cm alt., perenes, cespitosas, com rizomas curtos. Folhas eretas, lâminas 12-20 $\mathrm{cm} \times 0,5 \mathrm{~mm}$, filiformes, escabras especialmente nas margens. Colmos triangulares, glabros. Brácteas involucrais 3-5, a inferior 1-2 cm compr., mais curta do que a inflorescência. Antelódio simples, 4-7 cm compr., espiguetas isoladas no ápice dos ramos. Espiguetas 5-6 × 1-1,5 mm, cilíndricas; glumas 
espiraladas, largamente ovais, margens não hialinas, pubescentes, ápice curtamente mucronado. Estames 3. Aquênio ca. $0,8 \times 0,6 \mathrm{~mm}$, obovóide, superfície transversalmente rugosa.

Material examinado: $20^{\circ} 30^{\prime} 18,9$ 'S $43^{\circ} 36^{\prime} 28,6$ 'W, 8.V.2004, fl. e fr., R.A.X. Borges 19 (ICN, OUPR); 20³0'22"S 4337'50,8'W, 9.I.2006, fl. e fr., H.M. LonghiWagner \& C.C. de Paula 10003 (ICN, VIC); 20³0'19,4”'S 4337'56,1'W, 2.XII.2007, fl. e fr., H.M. Longhi-Wagner et al. $10368(\mathrm{~K}) ; 20^{\circ} 29^{\prime} 14,5^{\prime}$ 'S 4341'13,9'W, 3.XII.2007, fl. e fr., H.M. Longhi-Wagner et al. 10402 (K); 20³0’31,4”'S 4347'10,4'W, 5.XII.2007, fl., H.M. Longhi-Wagner et al. 10501 (ICN, K); 20³0’31,1'S 4336'54,4”W, 5.XII.2007, fl. e fr., H.M. Longhi-Wagner et al. 10512 (K).

Bulbostylis juncoides ocorre do sul dos Estados Unidos até a Argentina (Adams 1994a). Está distribuída em todas as regiões do Brasil (Alves et al. 2013), embora Prata (2004) tenha referido a espécie apenas para o estado do Paraná. $\mathrm{Na}$ SOB é muito comum, sendo encontrada em campos graminosos quartzíticos e em campos com predomínio de Vellozia compacta Mart. ex Schult. f. (Velloziaceae), entre 1100 e 1440 m.s.m.

1.7. Bulbostylis paradoxa (Spreng.) Lindm., Bih. Kongl. Svenska Vetensk.-Akad. Handl.: 6 (Afd. 3, 9): 17. 1900.

Plantas 12-25 cm alt., anuais, base com caudex desenvolvido. Folhas rosuladas, prostradas, lâminas 9-14 cm × 0,5-0,7 mm, filiformes, escabras. Colmos triangulares, escabros. Brácteas involucrais 7-10, a mais inferior 7,5-8 cm compr., mais curta do que a inflorescência. Inflorescência monocéfala, 1-1,2 $\times 1 \mathrm{~cm}$, espiguetas 10-20. Espiguetas 4-5 × 1,5-2 mm, cilíndricas; glumas espiraladas, ovallanceoladas, margem não hialina, ciliadas, ápice mucronado, múcron levemente recurvado. Estames 3. Aquênio $(0,7) 1-1,5 \times(0,5) 1-1,2$ mm, obovóide, superfície transversalmente rugulosa.

Material examinado: 1.X.1988, fl. e fr., R.V. Flor et al. (BHCB 14268); 2.X.1988, fl. e fr., G.A. Ferreira (BHCB 13820); 19.IX.1990, fl., R.J. Valka Alves \& J. Becker 1522 (ICN, R); 20³0'6,4”S 43³8'10,3”W, 20.III.2004, fl. e fr., R.A.X. Borges 3 (OUPR); 20³0'22''S 4337'59,3'W, 2.XII.2007, veg., H.M. Longhi-Wagner et al. 10333 (ICN); 20³0'22”S 4337'59,3”'W, 2.XII.2007, fl. H.M. Longhi-Wagner et al. 10353 (ICN, K); 20³0'15,7'S 4342'58,9'W, 2.XII.2007, fl. H.M. Longhi-Wagner et al. 10363 (ICN); 20²9'15,7’'S 4342'58,9'W, 4.XII.2007, fl., H.M. Longhi-Wagner et al. 10479 (ICN, K).

Bulbostylis paradoxa está amplamente distribuída nos Neotrópicos, desde o sul do México até a Venezuela e Bolívia (Adams 1994a) e Brasil, ocorrendo nas áreas de cerrado e campos rupestres do Centro-Oeste e Sudeste (Araújo et al. 2007) e também nas Regiões Norte e Nordeste (Prata 2004). Na SOB é abundante, sendo encontrada em campos graminosos quartzíticos e junto a afloramentos rochosos, entre 1150 e 1520 m.s.m., florescendo após o fogo. Espécie facilmente reconhecida pela presença de caudex e folhas basilares dispostas na forma de roseta.

1.8. Bulbostylis sphaerocephala (Boeck.) Lindm., Bih. Kongl. Svenska Vetensk. Akad. Handl. 26(9): 18 (1901).

Fig. $1 \mathrm{q}$

Plantas 25-50 cm alt., perenes, com rizomas curtos. Folhas eretas ou pendentes, lâminas 10-20 $\mathrm{cm} \times 0,5 \mathrm{~mm}$, filiformes, escabras. Colmos triangulares ou cilíndricos, glabros. Brácteas involucrais 6-8, a mais inferior $1,5-2(3) \mathrm{cm}$ compr., mais longa do que a inflorescência. Inflorescência monocéfala, ca. $0,7 \times 0,9 \mathrm{~cm}$, espiguetas 20-40. Espiguetas 3-3,5 × 0,8-1 mm, subcomprimidas lateralmente; glumas subdísticas, oval-lanceoladas, margens hialinas, glabras, ápice mucronado. Estames 2. Aquênio 0,9 ×0,5-0,6 mm, obovóide, superfície papilosa.

Material examinado: $20^{\circ} 29^{\prime} 6,1$ "S $43^{\circ} 43^{\prime} 3,4$ "W, 9.I.2006, fl., H.M. Longhi-Wagner \& C.C. de Paula 10014 (ICN, VIC); 20²8'51,4”S 4343'11,4”W, 9.I.2006, fl., H.M. Longhi-Wagner \& C.C. de Paula 10045 (ICN, VIC); 20²9'14,5'S 4341'13,9'W, 3.XII.2007, fl., H.M. Longhi-Wagner et al. 10398 (ICN, VIC).

Material adicional: MINAS GERAIS: São Roque de Minas, 19.XI.1995, fl. e fr., J. Nakajima et al. 1473 (K).

Bulbostylis sphaerocephala é citada para a Bolívia, Paraguai, Argentina e Brasil e, neste último país, nas Regiões Centro-Oeste, Sudeste e Sul, em cerrado, campo rupestre e brejos de solos arenosos (Prata 2004). Na SOB foi encontrada em campos graminosos quartzíticos e em campos com afloramentos rochosos, a 1400 m.s.m.

Alves et al. (2013) citaram esta espécie como Bulbostylis sphaerocephala (Boeck.) Clarke, porém, neste trabalho estão sendo aceitos os autores da espécie conforme referido em WCSP (2013). Esta espécie tem sido confundida com B. major Palla, não registrada na $\mathrm{SOB}$. Contudo, esta última distinguese pela forma da base da bráctea involucral e pela forma da inflorescência (Prata 2004).

1.9. Bulbostylis tenuifolia (Rudge) J.F. Macbr., Field Mus. Nat. Hist., Bot. Ser. 11: 5. 1931.

Fig. 1r-t

Plantas 7-18 cm alt., perenes, cespitosas, com rizomas curtos. Folhas eretas ou pendentes, lâminas 
4-7 cm $\times 0,2 \mathrm{~mm}$, filiformes, glabras. Colmos triangulares, glabros. Brácteas involucrais $2-3$, a inferior $0,5-0,6 \mathrm{~cm}$ compr., mais curta do que a inflorescência. Antelódio simples, 1-2 cm compr., espiguetas isoladas no ápice dos ramos. Espiguetas 3-4 × 0,8-1 mm, cilíndricas; glumas espiraladas, ovais, margens não hialinas, glabrescentes, ápice mútico. Estame 1. Aquênio ca. $0,7 \times 0,4 \mathrm{~mm}$, obovóide, superfície transversalmente rugosa.

Material examinado: $20^{\circ} 29^{\prime} 20^{\prime \prime} \mathrm{S} 43^{\circ} 41^{\prime} 47^{\prime \prime} \mathrm{W}$, 15.III.2005, fl. e fr., H.M. Longhi-Wagner et al. 9560 (ICN, VIC).

Bulbostylis tenuifolia distribui-se do México até o Brasil, incluindo as ilhas de Cuba e Jamaica (Adams 1994a). No Brasil foi citada para o Amazonas e Minas Gerais (Prata 2004) e, em Alves et al. (2013) apenas para o Domínio do Cerrado. $\mathrm{Na} \mathrm{SOB}$ foi encontrada em campos graminosos quartzíticos, a 1310 m.s.m.

1.10. Bulbostylis vestita (Kunth) C.B. Clarke, in Urban, Symb. Ant. 2: 87. $1900 . \quad$ Fig. 2a-d

Plantas (10)20-35 cm alt., perenes, cespitosas, com rizomas curtos. Folhas eretas, lâminas 7-10 $\mathrm{cm} \times 0,5-0,7 \mathrm{~mm}$, filiformes, hirsutas, tricomas 0,4-0,5 mm. Colmos cilíndricos, hirsutos. Brácteas involucrais 2(-3), a inferior $1-1,2 \mathrm{~cm}$ compr., mais longa do que a inflorescência. Inflorescência monocéfala, $0,6-0,8 \times 0,7-1 \mathrm{~cm}$, espiguetas ca. 50. Espiguetas 3-3,5 × 1,5-1,8 mm, cilíndricas; glumas espiraladas, ovais, margens não hialinas, pubescentes, ápice mútico. Estames 3. Aquênio 0,8-1 $\times 0,6-0,7 \mathrm{~mm}$, obovóide, superfície papilosa. Material examinado: $20^{\circ} 29^{\prime} 31,8^{\prime \prime} \mathrm{S} 43^{\circ} 42^{\prime} 2,8^{\prime \prime} \mathrm{W}$, 8.I.2006, fl. e fr., H.M. Longhi-Wagner \& C.C. de Paula 9975 (ICN, VIC); 20³0'12,2”'S 4340'18,8”W, 10.I.2006, fl. e fr., H.M. Longhi-Wagner \& C.C. de Paula 10062 (ICN).

Bulbostylis vestita ocorre do México até o Brasil e Paraguai. No Brasil, ocorre em áreas de cerrado, campo rupestre e ao longo de rodovias (Kral 1971). É comum na SOB, em campos graminosos quartzíticos, entre ca. 1280 e 1460 m.s.m. Segundo Kral (1971, 1998), Bulbostylis vestita apresenta variação na inflorescência, desde monocéfala até antelódio formado por espiguetas sésseis no ápice dos ramos sendo que variação similar também foi referida para B. junciformis. Entretanto, esta variação não foi encontrada no material da $\mathrm{SOB}$, onde $B$. vestita sempre apresentou inflorescência capitada com espiguetas sésseis e $B$. junciformis, antelóide com espiguetas pediceladas, sendo ambas, frequentemente, encontradas em simpatria.
Além disto, $B$. vestita apresenta plantas hirsutas, enquanto $B$. junciformis, plantas glabras. Bulbostylis vestita também assemelha-se a $B$. guaglianoneae M.G. López, descrita para a Argentina, pelo hábito, inflorescência e tipo de ornamentação do aquênio. Porém, as plantas de $B$. guaglianoneae apresentam maior porte, atingindo $60 \mathrm{~cm}$ de altura, inflorescência maior, com 1,5-2 cm de diâmetro, espiguetas com 3-7 mm de comprimento, aquênios mais longos, com 1,2-1,25 mm de comprimento, e apenas dois estames (López 2007).

\subsection{Bulbostylis sp.}

Plantas 18-25 cm alt., perenes, cespitosas, com rizomas curtos. Folhas eretas ou pendentes, lâminas $5-10 \mathrm{~cm} \times 0,3-0,5 \mathrm{~mm}$, filiformes, hirsutas, tricomas ca. $0,2 \mathrm{~mm}$. Colmos cilíndricos, hirsutos. Brácteas involucrais 3-4, a inferior 2,5-3 $\mathrm{cm}$ compr., mais longa do que a inflorescência. Antelódio simples, 1,5-2 cm compr., espiguetas isoladas no ápice dos ramos. Espiguetas 2,5-2,8 $\times 0,7-1 \mathrm{~mm}$, cilíndricas; glumas espiraladas, ovais, margens não hialinas, pubescentes, ápice mucronado. Estames 2. Aquênio ca. 0,8 ×0,6 mm, obovóide, superfície papilosa.

Material examinado: $20^{\circ} 29^{\prime} 6,5^{\prime} \mathrm{S} 43^{\circ} 42^{\prime} 39,7^{\prime \prime} \mathrm{W}$, 8.I.2006, fl. e fr., H.M. Longhi-Wagner \& C.C. de Paula 9971 (ICN).

Bulbostylis sp. foi encontrada na SOB em campos brejosos, com solos arenoso-quartzíticos, a ca. 1560 m.s.m. Esta coleção apresenta folhas hirsutas, como $B$. hirtella, atualmente aceita como sinônimo de B. juncoides (Alves et al. 2013). Embora o exemplar analisado apresente, predominantemente, espiguetas jovens, alguns frutos maduros foram encontrados, claramente confirmando que se trata de uma entidade taxonômica distinta. Novas coletas são necessárias para avaliar esse material.

O gênero Bulbostylis apresenta taxonomia bastante complexa, com dificuldade na delimitação de espécies, às vezes separadas por caracteres que, eventualmente, poderiam sofrer variação ambiental. Ainda não existem dados disponíveis incluindo avaliação deste aspecto para as espécies morfologicamente muito semelhantes ocorrentes nos Neotrópicos. Uma análise da variação populacional e de sua relação com ambientes diversos, bem como da circunscrição dos complexos de espécies morfologicamente muito próximas ou com grande variação morfológica é urgentemente necessária para este gênero. 

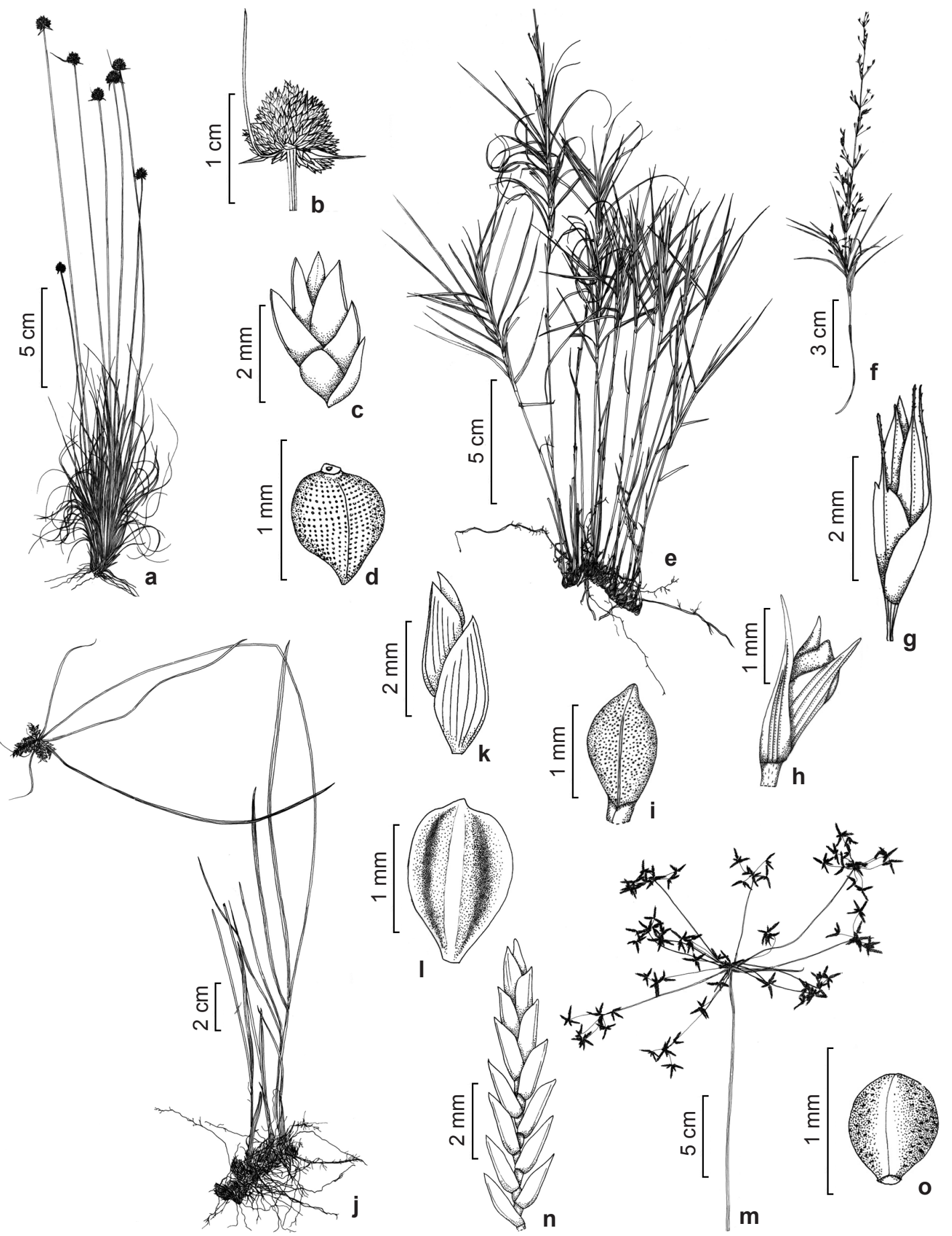

Figura 2 - a-d. Bulbostylis vestita - a. hábito; b. inflorescência; c. espigueta; d. aquênio. e-i. Cryptangium junciforme - e. hábito; f. inflorescência; g. espigueta estaminada; h. espigueta pistilada; i. aquênio. j-1. Cyperus aggregatus - j. hábito; k. espigueta; 1. aquênio, faces côncavas. m-o. C. haspan - m. inflorescência; n. espigueta; o. aquênio (a-d H.M. Longhi-Wagner \& C.C. de Paula 9975; e-i H.M. Longhi-Wagner \& C.C. de Paula 9963; j-1 H.M. Longhi-Wagner \& C.C. de Paula 9999; m-o H.M. Longhi-Wagner \& C.C. de Paula 10038).

Figure 2 - a-d. Bulbostylis vestita - a. habit; $b$. inflorescence; c. spikelet; d. achene. e-i. Cryptangium junciforme-e. habit; $\mathrm{f}$. inflorescence; g. male spikelet; h. female spikelet; i. achene. j-1. Cyperus aggregatus - j. habit; k. spikelet; 1. achene, sunken sides. m-o. C. haspan - m. inflorescence; n. spikelet; o. achene (a-d H.M. Longhi-Wagner \& C.C. de Paula 9975; e-i H.M. Longhi-Wagner \& C.C. de Paula 9963; j-1 H.M. Longhi-Wagner \& C.C. de Paula 9999; m-o H.M. Longhi-Wagner \& C.C. de Paula 10038). 


\section{Cryptangium Schrad. ex Nees}

Plantas perenes, com rizomas curtos. Folhas formando pseudoverticilos no ápice do colmo, ou distribuídas ao longo do colmo, ou ainda, mais raramente, uma roseta basal com 1-3 folhas; bainhas e lâminas desenvolvidas, lígula ausente, contralígula presente, raramente ausente; bainhas com o ápice glabro, não hialino e não marcescente; lâminas conduplicadas, menos comumente planas. Colmos triangulares ou cilíndricos. Brácteas involucrais presentes. Inflorescência do tipo paniculódio, as espiguetas estaminadas nos ramos floríferos basais, as pistiladas nos ramos floriferos apicais. Espiguetas sésseis ou pediceladas, plurifloras, cilíndricas, glumas de disposição espiralada sobre a ráquila. Flores unissexuadas, perigônio representado por 3 escamas hipóginas em flores pistiladas, ausente nas estaminadas; estames 2(3); estigmas 3-fidos, base do estilete não dilatada e não persistente sobre o fruto, estilopódio ausente. Aquênio com seção transversal trígona, não alado, não envolto por um utrículo, superfície lisa, tuberculada ou, mais raramente, finamente papilosa (adaptada de Vitta 2005).

Cryptangium inclui aproximadamente 14 espécies predominantemente brasileiras, com poucas espécies de distribuição tropical nas Américas do Sul e Central (Vitta 2005). Está representado na SOB por apenas uma espécie.

\subsection{Cryptangium junciforme (Kunth) Boeck.,} Linnaea 38: 415. 1874.

Fig. 2e-i

Plantas $20-30 \mathrm{~cm}$ alt. Folhas formando pseudoverticilos no ápice do colmo contralígula triangular, glabra; lâminas planas, ca. 3,5-5 cm $\times$ $3 \mathrm{~mm}$. Colmos triangulares. Paniculódio 10-16 cm compr., espiguetas isoladas. Espiguetas estaminadas 3,2-4 × 1,5 mm, castanho-amarronzadas; estames 2 . Espiguetas pistiladas $2-3 \times 1-1,2 \mathrm{~mm}$, castanhoamarronzadas. Aquênio 1,3-1,5 × 0,8-1 mm, elipsóide, superfície finamente papilosa.

Material examinado: $20^{\circ} 29^{\prime} 6,5^{\prime \prime} \mathrm{S} 43^{\circ} 42^{\prime} 39,7^{\prime \prime} \mathrm{W}$, 8.I.2006, fl. e fr., H.M. Longhi-Wagner \& C.C. de Paula 9963 (ICN).

Cryptangium junciforme é endêmica de Minas Gerais (Vitta 2005). Na SOB é rara e foi encontrada em afloramentos rochosos, a 1560 m.s.m.

\section{Cyperus L.}

Plantas perenes, raramente anuais, com ou sem rizomas. Folhas basilares, com bainhas e lâminas desenvolvidas (raramente lâminas ausentes), lígula e contralígula ausentes, muito raramente lígula presente, muito reduzida (C. rotundus L.); bainhas com o ápice glabro, não hialino e não marcescente; lâminas planas. Colmos triangulares, raramente cilíndricos. Brácteas involucrais presentes. Inflorescência do tipo antelódio simples ou composto, ou inflorescência monocéfala. Espiguetas sésseis ou pediceladas, plurifloras, comprimidas lateralmente, glumas de disposição dística sobre a ráquila. Flores bissexuadas, perigônio ausente; estames 1-3; estigmas (2-)3-fidos, base do estilete não dilatada e não persistente sobre o fruto, estilopódio ausente. Aquênio com seção transversal trígona, raramente lenticular, não alado, não envolto por um utrículo, superfície lisa (Araújo \& LonghiWagner 1996; Hefler \& Longhi-Wagner 2012).

Cyperus inclui aproximadamente 550 espécies distribuídas em regiões tropicais e subtropicais (Hefler \& Longhi-Wagner 2012). Está representado na SOB por duas espécies.

\section{Chave para espécies de Cyperus da Serra do Ouro Branco}

1. Lâminas foliares presentes, 3,5-4 mm larg. Antelódio formado por 3-5 espigas no ápice do colmo, cada espiga com 30-40 espiguetas sésseis densamente agrupadas. Espiguetas 3,5-4 mm compr. Aquênio castanho

3.1. Cyperus aggregatus

1'. Lâminas foliares geralmente ausentes, quando presentes, apenas uma, ca. $6 \mathrm{~mm}$ larg. Antelódio formado por mais de 10 fascículos laxos no ápice de ramos longos, cada um com 3-6 espiguetas pediceladas. Espiguetas (8)10-20 mm compr. Aquênio branco 3.2. Cyperus haspan

\subsection{Cyperus aggregatus (Willd.) Endl., Cat. Horti Vindob. 1: 93. 1842. \\ Fig. $2 \mathrm{j}-1$}

Plantas $20-50 \mathrm{~cm}$ alt., perenes, com rizomas curtos. Lâminas foliares 10-20 cm × 3,5-4 mm. Colmos triangulares. Brácteas involucrais 5-6, a inferior 10-15 $\mathrm{cm}$ compr. Antelódio $1,5 \times 2 \mathrm{~cm}$, formado por 3-5 espigas de ca. 1-2 × 0,5 cm no ápice do colmo, cada espiga portando 30-40 espiguetas sésseis densamente agrupadas. Espiguetas 3,5-4 × 1-1,2 mm, palhetes, carena esverdeada. Estames 3. Estigmas 3. Aquênio ca. 1,3-1,5 × $1 \mathrm{~mm}$, obovóide, com seção transversal trígona, faces côncavas, castanho. 
Material examinado: $20^{\circ} 30^{\prime} 20,3$ 'S 4337'53,9'W, 9.I.2006, fl. e fr., H.M. Longhi-Wagner \& C.C. de Paula 9999 (ICN).

Cyperus aggregatus ocorre na região neotropical, estendendo-se até áreas subtropicais, adventícia na Austrália (Hefler \& Longhi-Wagner 2012). No Brasil, ocorre principalmente como ruderal (Hefler \& Longhi-Wagner 2012). Na SOB também foi encontrada em ambiente ruderal, sendo pouco comum. A espécie caracteriza-se pelas espigas sésseis e densamente contraídas no ápice do colmo.

\subsection{Cyperus haspan L., Sp. Pl.: 45. 1753.}

Fig. $2 \mathrm{~m}-\mathrm{o}$

Plantas 75-90 cm alt., perenes, com rizomas curtos. Lâminas foliares geralmente ausentes, quando presentes, apenas uma, ca. $10-15 \mathrm{~cm} \times$ $6 \mathrm{~mm}$. Colmos triangulares. Brácteas involucrais 2-3, a inferior 4-5,5 cm compr. Antelódio 7-12 cm compr., laxo, 3-6 espiguetas pediceladas agrupadas em mais de 10 fascículos laxos no ápice de ramos longos. Espiguetas (8-)10-20 $\times 1,5-2 \mathrm{~mm}$, vináceas, esverdeadas na quilha. Estames 3. Estigmas 3. Aquênio 0,7-1 × 0,5-0,6 $\mathrm{mm}$, largamente elipsóide, com seção transversal trígona, faces planas a levemente convexas, branco. Material examinado: $20^{\circ} 28^{\prime} 51,4$ "S $43^{\circ} 43^{\prime} 11,4$ 'W, 9.I.2006, fl. e fr., H.M. Longhi-Wagner \& C.C. de Paula 10038 (ICN, VIC).

Cyperus haspan é pantropical. No Brasil ocorre em ambientes campestres, baixos e úmidos, de solos arenosos (Araújo \& Longhi-Wagner 1996). $\mathrm{Na} \mathrm{SOB}$ é pouco comum e foi encontrada em campos brejosos, junto a curso d'água, a 1450 m.s.m. Espécie reconhecida por suas espiguetas vináceas e, geralmente, ausência de lâminas foliares.

\section{Eleocharis $\mathrm{R}$. Br.}

Plantas perenes, raramente anuais, com ou sem rizomas ou estolhos. Folhas reduzidas às bainhas, lâminas ausentes, lígula e contralígula ausentes; bainhas com o ápice glabro, hialino e marcescente, ou não hialino e não marcescente, abertura da bainha oblíqua ou reta, ápice obtuso, subagudo, agudo ou mucronado. Colmos cilíndricos ou 3-4-5-angulares. Brácteas involucrais ausentes. Inflorescência composta de uma espigueta única no ápice do colmo. Espiguetas sésseis, plurifloras, cilíndricas ou subcilíndricas, glumas de disposição espiralada sobre a ráquila, mais raramente espiguetas subcomprimidas lateralmente, glumas subdísticas ou dísticas, glabras. Flores bissexuadas, perigônio representado por cerdas perigoniais escabras, ou ausente; estames 1-3; estigmas 2-3-fidos, base do estilete dilatada sobre o fruto, persistente, formando um estilopódio geralmente triangular, ou de formatos variados, não alado, nunca um tubérculo. Aquênio com seção transversal trígona ou lenticular, não alado, não envolto por um utrículo, superfície lisa, estriada, tuberculada, papilosa, reticulada ou transversalmente rugosa (adaptada de Trevisan \& Boldrini 2008).

Eleocharis é um gênero cosmopolita mais concentrado nas regiões tropicais e subtropicais da América (Trevisan \& Boldrini 2008), com ca. 150 espécies (González 1994). Está representado na SOB por três espécies.

\section{Chave para espécies de Eleocharis da Serra do Ouro Branco}

1. Ápice da bainha hialino e marcescente, tornando-se rugoso. Estigmas 2-fidos. Aquênio biconvexo, superfície lisa 4.2. Eleocharis sellowiana

1'. Ápice da bainha não hialino, de consistência igual ao restante da bainha, ou levemente hialino, mas não marcescente, nem rugoso. Estigmas 3-fidos. Aquênio triangular, superfície levemente estriada ou fortemente reticulada.

2. Colmos quadrangulares. Cerdas perigoniais $0,4-0,5 \mathrm{~mm}$ compr., atingindo ca. $1 / 4$ do comprimento do fruto. Aquênio liso a levemente estriado 4.1. Eleocharis loefgreniana

2'. Colmos cilíndricos. Cerdas perigoniais $0,8-1,5 \mathrm{~mm}$ compr., atingindo $3 / 4$ até o comprimento do fruto, às vezes ultrapassando-o. Aquênio fortemente reticulado 4.3. Eleocharis squamigera

4.1. Eleocharis loefgreniana Boeck., Beitr. Cyper. 2: 12.1890 .

Fig. 3a-d

Plantas ca. $12 \mathrm{~cm}$ alt., perenes, cespitosas. Bainhas com o ápice estreitamente agudo, não hialino, às vezes levemente hialino, não marcescente, abertura reta. Colmos quadrangulares. Espiguetas 3,8-4 × 1,2-1,8 mm, subcilíndricas, glumas espiraladas, glabras. Cerdas perigoniais $0,4-0,5 \mathrm{~mm}$ compr., atingindo ca. $1 / 4$ do comprimento do fruto, às vezes pouco conspícuas. Estames 
3. Estigmas 3-fidos. Aquênio 1-1,3 × 0,7 mm, obovóide, triangular, superfície lisa a levemente estriada, esbranquiçado a palhete; estilopódio ca. $0,4 \mathrm{~mm}$ compr., triangular.

Material examinado: $20^{\circ} 29^{\prime} 18,5^{\prime \prime} \mathrm{S} 43^{\circ} 41^{\prime} 3,8^{\prime \prime} \mathrm{W}$, 3.XII.2007, fl. e fr., H.M. Longhi-Wagner et al. 10406 (ICN, K).

Eleocharis loefgreniana foi citada apenas para a Argentina e Brasil, nos estados de Minas Gerais, São Paulo e Rio Grande do Sul (Trevisan \& Boldrini 2008). Na SOB foi encontrada em campos brejosos, junto a curso d'água, a 1390 m.s.m., associada a indivíduos de Eleocharis squamigera.

4.2. Eleocharis sellowiana Kunth, Enum. Pl. 2: 149. 1837.

Fig. 3e-h

Plantas 20-25 cm alt., perenes, com rizomas, cespitoso-rizomatosas. Bainhas com o ápice agudo, conspicuamente hialino e marcescente, tornandose rugoso, abertura reta. Colmos cilíndricos. Espiguetas 5-6,5 × 1,8-2 mm, cilíndricas, glumas espiraladas, glabras. Cerdas perigoniais $0,7-1$ $\mathrm{mm}$ compr., atingindo ca. $3 / 4$ do fruto. Estames 3 . Estigmas 2-fidos. Aquênio ca. 0,8-1,1 × 0,7 mm, biconvexo, superfície lisa, castanho-oliváceo; estilopódio 0,4-0,6 mm compr. triangular.

Material examinado: $20^{\circ} 29^{\prime \prime} 18,5^{\prime \prime} \mathrm{S} 43^{\circ} 41^{\prime} 3,8^{\prime \prime} \mathrm{W}$, 3.XII.2007, fl. e fr., H.M. Longhi-Wagner et al. 10407 (ICN).

Eleocharis sellowiana ocorre nas Américas Central e do Sul. No Brasil ocorre nas Regiões Nordeste, Centro-Oeste, Sudeste e Sul (Trevisan \& Boldrini 2008). Na SOB foi encontrada em curso d'água estacional, junto a campos brejosos, a 1390 m.s.m.

4.3. Eleocharis squamigera Svenson, Rhodora 36: 389. 1934.

Fig. 3i-1

Plantas 12-15(25) cm alt., perenes, com estolhos longos. Bainhas com o ápice obtuso a subagudo, levemente hialino, não marcescente, abertura oblíqua. Colmos cilíndricos. Espiguetas 2-4×1,8-2 mm, subcilíndricas, glumas espiraladas, caracteristicamente divergentes, glabras. Cerdas perigoniais $0,8-1,5 \mathrm{~mm}$ compr., atingindo ca. $3 / 4$ até o comprimento do fruto, às vezes ultrapassando-o. Estames 2. Estigmas 3-fidos. Aquênio ca. 1-1,3 $\times 0,8 \mathrm{~mm}$, triangular, superfície fortemente reticulada, palhete a castanho-claro; estilopódio $0,3-0,5 \mathrm{~mm}$ compr., triangular.

Material examinado: $20^{\circ} 29^{\prime} 18,5^{\prime \prime} \mathrm{S} 43^{\circ} 41^{\prime} 3,8^{\prime \prime} \mathrm{W}$, 3.XII.2007, fl., H.M. Longhi-Wagner et al. $10406 a$

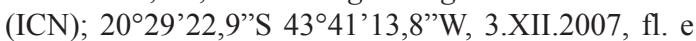
fr., H.M. Longhi-Wagner et al. 10418 (ICN).
Eleocharis squamigera ocorre na Venezuela e Brasil, tendo sido citada para a Região Sul até o estado de São Paulo (Trevisan \& Boldrini 2008). Na SOB, foi encontrada próximo a cursos d'água, tanto em campos brejosos, em população associada à Eleocharis loefgreniana, quanto junto à mata de galeria, a 1390 m.s.m. Este é um novo registro para o estado de Minas Gerais, constituindo-se no limite norte de ocorrência no Brasil conhecido até o momento.

\section{Fimbristylis Vahl}

Plantas perenes ou anuais, com ou sem rizomas. Folhas basilares, com bainhas e lâminas desenvolvidas, lígula raramente presente, contralígula ausente; bainhas com o ápice glabro, não hialino e não marcescente; lâminas planas. Colmos geralmente cilíndricos, às vezes 3-4-5-angulares, menos comumente achatados. Brácteas involucrais presentes. Inflorescência do tipo antelódio simples ou composto, terminal, espiguetas isoladas ou aos pares no ápice dos ramos. Espiguetas sésseis ou pediceladas, plurifloras, cilíndricas, glumas de disposição espiralada sobre a ráquila. Flores bissexuadas, perigônio ausente; estames 1-3; estigmas 2-3-fidos, base do estilete dilatada sobre o fruto e inteiramente caduca na maturação, estilopódio ausente. Aquênio com seção transversal lenticular ou trígona, não alado, não envolto por um utrículo, superfície transversalmente rugosa ou tuberculada (adaptada de Adams 1994b; Goetghebeur 1998).

Fimbristylis inclui ca. 200 (Adams 1994b) a 300 espécies de ampla distribuição tropical (Goetghebeur 1998). Está representado na SOB por uma espécie.

5.1. Fimbristylis complanata (Retz.) Link, Hort. Berol. 1: 292. 1827. Fig. $3 m-p$

Plantas 30-40 cm alt., perenes, sem rizomas. Folhas com lígula pilosa; lâminas foliares ca. $15-20 \mathrm{~cm} \times 0,5 \mathrm{~mm}$. Colmos fortemente achatados. Brácteas involucrais $2(-3)$, a inferior $2-4,5 \mathrm{~cm}$ compr., mais longa do que a inflorescência. Antelódio composto, 4-6 cm compr., espiguetas pediceladas reunidas em fascículos congestos. Espiguetas ca. $7 \times 2 \mathrm{~mm}$, castanhas; glumas ovallanceoladas. Estames 3. Estigmas 3-fidos. Aquênio ca. $0,7 \times 0,5 \mathrm{~mm}$, com seção transversal trígona, superfície tuberculada.

Material examinado: $20^{\circ} 28^{\prime} 51,4^{\prime \prime} \mathrm{S} 43^{\circ} 43^{\prime} 11,4^{\prime \prime} \mathrm{W}$, 9.I.2006, fl. e fr., H.M. Longhi-Wagner \& C.C. de Paula 10019 (ICN, VIC). 

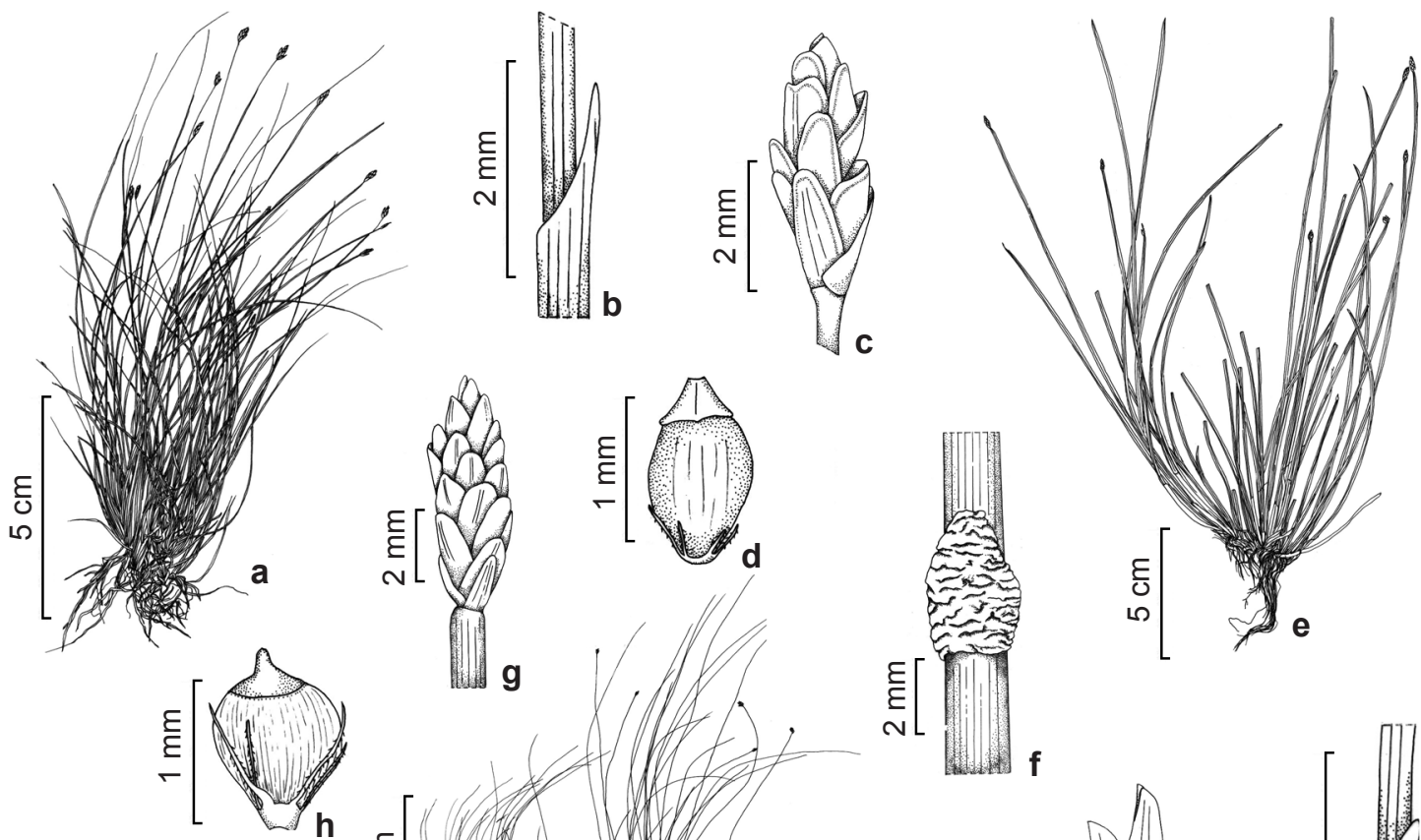

$\stackrel{\varepsilon}{N}[$
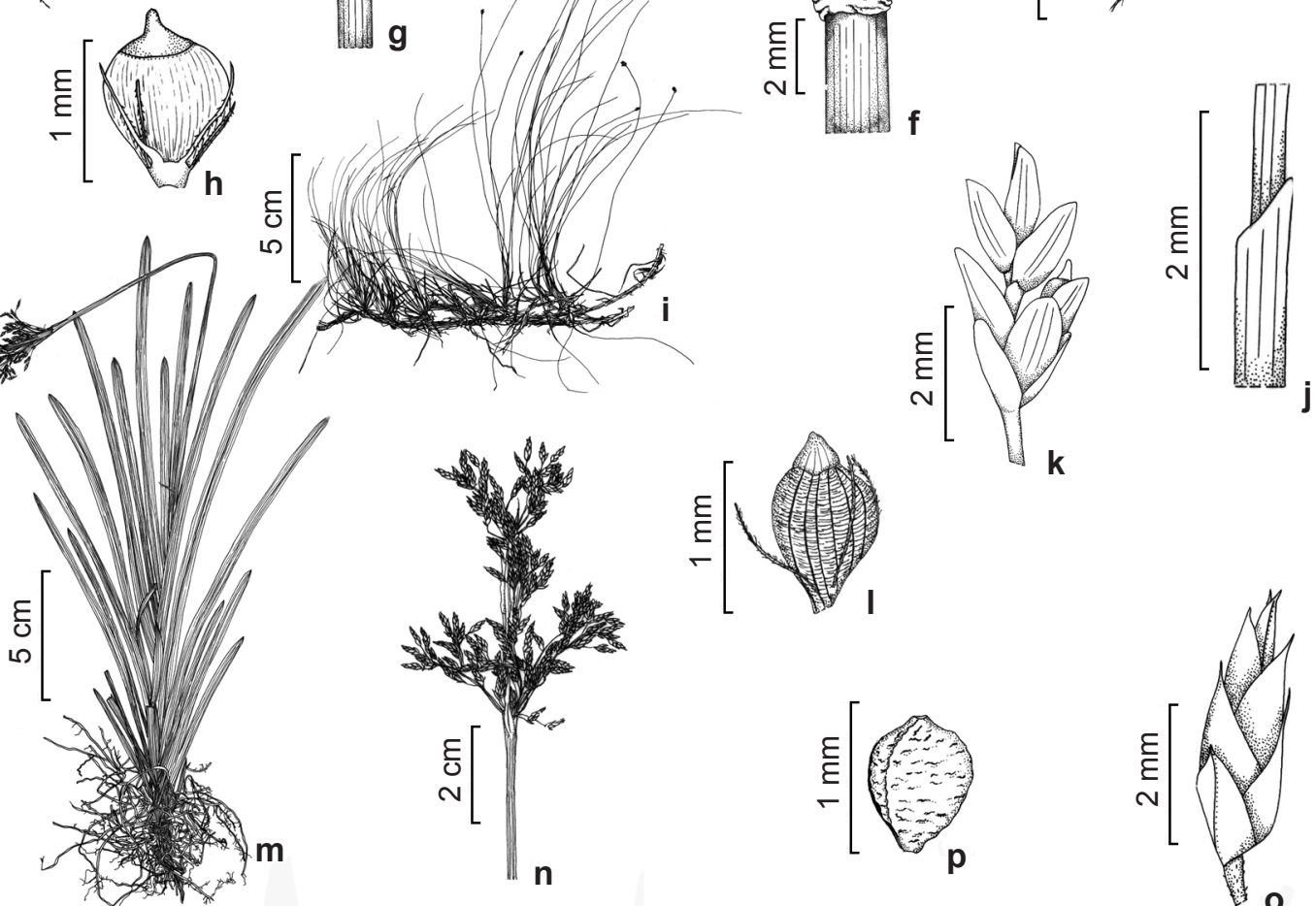

Figura 3 - a-d. Eleocharis loefgreniana - a. hábito; b. ápice da bainha foliar; c. espigueta; d. aquênio. e-h. E. sellowiana - e. hábito; f. ápice da bainha foliar; g. espigueta; h. aquênio. i-1. E. squamigera - i. hábito; j. ápice da bainha foliar; k. espigueta; 1. aquênio. m-p. Fimbristylis complanata - m. hábito; n. inflorescência, variação; o. espigueta; p. aquênio (a-d H.M. Longhi-Wagner et al. 10406; e-h H.M. Longhi-Wagner et al. 10407; i-1 H.M. Longhi-Wagner et al. 10418 ; m-p H.M. Longhi-Wagner \& C.C. de Paula 10019).

Figure 3 - a-d. Eleocharis loefgreniana - a. habit; b. apex of leaf sheath; c. spikelet; d. achene. e-h. E. sellowiana - e. habit; f. apex of leaf sheath; g. spikelet; h. achene. i-1. E. squamigera -i. habit; j. apex of leaf sheath; k. spikelet; 1. achene. m-p. Fimbristylis complanata - m. habit; n. inflorescence variation; o. spikelet; p. achene (a-d H.M. Longhi-Wagner et al. 10406; e-h H.M. Longhi-Wagner et al. 10407; i-1 H.M. Longhi-Wagner et al. 10418; m-p H.M. Longhi-Wagner \& C.C. de Paula 10019).

Fimbristylis complanata é pantropical, ocorrendo também em zonas subtropicais (Kral 1971; Adams 1994b). No Brasil é referida para todos os Domínios fitogeográficos (Alves et al.
2013). Na SOB é pouco comum, sendo encontrada em campos brejosos, junto a curso d'água, a 1450 m.s.m. Esta espécie pode ser facilmente confundida com $F$. autumnalis $\mathrm{L}$. visto que ambas compartilham 
três estigmas e colmo achatado. Contudo, diferem no modo de vida, anual em $F$. autumnalis e perene em $F$. complanata, bem como no comprimento do fruto, menor na primeira espécie, de 0,4 a $0,5 \mathrm{~mm}$ (Adams 1994b).

\section{Lagenocarpus Nees}

Plantas perenes, com rizomas curtos, raramente estoloníferas. Folhas basilares, com bainhas e lâminas desenvolvidas, lígula ausente, contralígula presente; bainhas com o ápice glabro, não hialino e não marcescente; lâminas planas, conduplicadas ou subcilíndricas. Colmos triangulares ou subcilíndricos. Brácteas involucrais presentes. Inflorescência do tipo paniculódio, as espiguetas estaminadas nos ramos floríferos basais, as pistiladas nos ramos floriferos apicais. Espiguetas sésseis ou pediceladas, plurifloras, as estaminadas comprimidas lateralmente, glumas de disposição dística a subdística sobre a ráquila, as pistiladas cilíndricas, glumas de disposição espiralada. Flores unissexuadas, perigônio ausente ou representado por escamas hipóginas nas flores pistiladas, ausente nas estaminadas; estames 1 (2-5); estigmas 3(4-5)-fidos, base do estilete não dilatada e não persistente sobre o fruto, estilopódio ausente. Aquênio com seção transversal circular, não alado, não envolto por um utrículo, superfície lisa ou finamente papilosa (adaptada de Vitta 2005).

Lagenocarpus inclui ca. 12 espécies com maior diversidade na Região Sudeste do Brasil e no Planalto das Guianas (Vitta 2005). Está representado na SOB por duas espécies.

\section{Chave para as espécies de Lagenocarpus da Serra do Ouro Branco}

1. Plantas 100-170 cm alt. Lâminas foliares 6-7 mm larg. Paniculódio 30-35 compr. Colmos triangulares 6.1. Lagenocarpus rigidus

1'. Plantas 60-65 cm alt. Lâminas foliares 0,5-0,7 mm larg. Paniculódio 10-25 cm compr. Colmos subcilíndricos 6.2 Lagenocarpus tenuifolius

6.1. Lagenocarpus rigidus (Kunth) Nees, in Mart., Fl. bras. 2(1): 167. 1842.

Plantas 100-170 cm alt., rizomas curtos. Lâminas foliares planas, $20-35 \mathrm{~cm} \times 6-7 \mathrm{~mm}$, glabras. Colmos triangulares. Brácteas involucrais foliáceas, uma por ramo florífero. Paniculódio 30-35 cm compr., espiguetas pediceladas, 30-50 agrupadas em fascículos laxos. Espiguetas estaminadas 5-7 $54 \mathrm{~cm}$, castanhas; estame 1 . Espiguetas pistiladas 2,5-3 × 0,5 cm, castanhas; perigônio ausente; estigmas 3 . Aquênio 2,5-3 $\times$ $1,5 \mathrm{~mm}$, globoso, superfície finamente papilosa. Material examinado: 2.X.1988, fl. e fr., V.M. Soares (BHCB 14347); 20³0’617,6”S 4339'26,6”'W, 23.III.2004, fl. e fr., R.A.X. Borges 116 (OUPR); $20^{\circ} 29^{\prime} 6,3^{\prime \prime}$ S $43^{\circ} 42^{\prime} 40,8^{\prime \prime}$ W, 8.I.2006, fl. e fr., H.M. Longhi-Wagner \& C.C. de Paula 9949 (ICN, VIC); $20^{\circ} 28^{\prime} 52^{\prime}$ 'S $43^{\circ} 43^{\prime} 40,9$ 'W, 4 .XII.2007, fl. e fr., H.M. Longhi-Wagner et al. 10460 (ICN, VIC).

Lagenocarpus rigidus é amplamente distribuída na Região Neotropical (Vitta 2005). Ocorre em todas as regiões do Brasil, com limite austral em Santa Catarina (Vitta 2005). Na SOB é muito comum em afloramentos rochosos e nas encostas rochosas, entre 1100 e 1580 m.s.m. As plantas desta espécie formam touceiras robustas com lâminas caracteristicamente acinzentadas, sendo também reconhecidas por sua inflorescência com os ramos masculinos e femininos em partes distintas do colmo.

6.2. Lagenocarpus tenuifolius (Boeck.) C.B. Clarke, Bull. Misc. Inform., Add. Ser. 8: 64. 1908.

Fig. 4a-e

Plantas 60-65 cm alt., rizomas curtos. Lâminas foliares conduplicadas, $25-30 \mathrm{~cm} \times 0,5-0,7 \mathrm{~mm}$, glabras. Colmos subcilíndricos. Brácteas involucrais glumiformes, uma por ramo florífero. Paniculódio 10-25 cm compr., espiguetas pediceladas, 3-4 agrupadas em fascículos laxos. Espiguetas estaminadas 5-6 × 1,5 mm, castanhas; estames 3 . Espiguetas pistiladas 5-7 $\times 3-3,5 \mathrm{~mm}$, castanhas; perigônio ausente; estigmas 3. Aquênio 3-4× 1-1,6 $\mathrm{mm}$, oblongo, superfície finamente papilosa.

Material examinado: $20^{\circ} 30^{\prime} 22^{\prime \prime} \mathrm{S} 43^{\circ} 37^{\prime} 50,8^{\prime} \mathrm{W}$, 9.I.2006, fl. e fr., H.M. Longhi-Wagner \& C.C. de Paula 10002 (ICN, VIC).

Lagenocarpus tenuifolius foi citada por Vitta (2005) apenas para o Brasil, nas Regiões Nordeste, Sudeste e Centro-Oeste, em vegetação de cerrado e campo rupestre. Na SOB é pouco comum e foi encontrada em solos arenoso-quartzíticos, junto a afloramentos rochosos, a 1280 m.s.m. Distingue-se da espécie anterior por seu porte menor, colmos subcilíndricos e lâminas bem mais estreitas. 

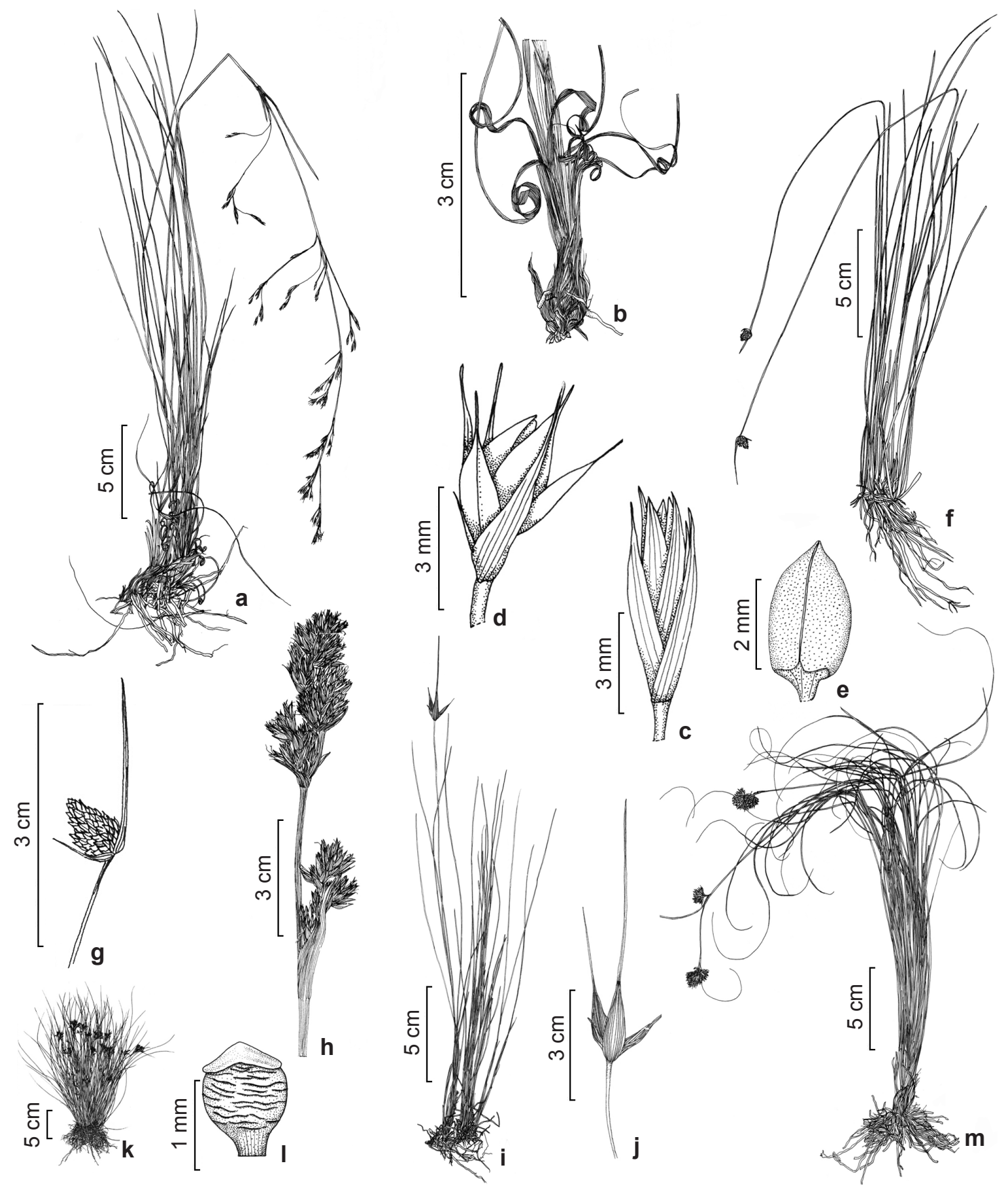

Figura 4 -a-e. Lagenocarpus tenuifolius - a. hábito; b. base da planta; c. espigueta estaminada; d. espigueta pistilada; e. aquênio. f-g. Lipocarpha cf. chinensis - f. hábito; g. inflorescência. h. Machaerina ensifolia - inflorescência. i-j. Rhynchospora albobracteata - i. hábito; j. inflorescência. k-1. R. brevirostris - k. hábito; 1. aquênio. m. R. ciliolata - hábito (a-e H.M. Longhi-Wagner \& C.C. de Paula 10002; f-g H.M. Longhi-Wagner et al. 10409; h H.M. LonghiWagner et al. 10424; i-j H.M. Longhi-Wagner \& C.C. de Paula 9564; k-1 F.O.A. Lemes s.n. - OUPR 21801; m H.M. Longhi-Wagner et al. 9553a).

Figure 4 - a-e. Lagenocarpus tenuifolius - a. habit; b. plant rizome; c. male spikelet; d. female spikelet; e. achene. f-g. Lipocarpha cf. chinensis - f. habit; g. inflorescence. h. Machaerina ensifolia - inflorescence. i-j. Rhynchospora albobracteata - i. habit; j. inflorescence. k-1. R. brevirostris - k. habit; 1. achene. m. R. ciliolata - habit (a-e H.M. Longhi-Wagner \& C.C. de Paula 10002; f-g H.M. LonghiWagner et al. 10409; h H.M. Longhi-Wagner et al. 10424; i-j H.M. Longhi-Wagner \& C.C. de Paula 9564; k-1 F.O.A. Lemes s.n. - OUPR 21801; m H.M. Longhi-Wagner et al. 9553a). 


\section{Lipocarpha $\mathrm{R}$. Br.}

Plantas anuais ou perenes, com ou sem rizomas. Folhas basilares, com bainhas e lâminas desenvolvidas, lígula e contralígula ausentes; bainhas com o ápice glabro, não hialino e não marcescente; lâminas planas ou convolutas. Colmos subtriangulares ou inconspicuamente triangulares. Brácteas involucrais presentes. Inflorescência composta por uma espiga terminal e 3-5 espigas pseudolaterais, mais raramente composta de uma só espiga pseudolateral, cada espiga formada por brácteas glumáceas espiraladas sobre a ráquis, cada bráctea subentendendo uma espigueta. Espiguetas sésseis, unifloras, comprimidas dorsiventralmente, com uma gluma reduzida e hialina ou apenas com um profilo reduzido e hialino subentendendo a flor, ou gluma e profilo ausentes. Flores bissexuadas, perigônio ausente; estames 1-3; estigmas 2-3-fidos, base do estilete não dilatada e não persistente sobre o fruto, estilopódio ausente. Aquênio com seção transversal suborbicular ou subtrígona a pseudolenticular, não alado, não envolto por um utrículo, superfície finamente pontuada (Adams \& Goetghebeur 1994).

Lipocarpha inclui ca. 30-35 espécies tropicais e subtropicais (Adams \& Goetghebeur 1994; Goetghebeur 1998). Está representado na SOB por uma espécie.

\subsection{Lipocarpha ef. chinensis (Osbeck) J. Kern,} Blumea, Suppl.t 4: 167. $1958 . \quad$ Fig. 4f-g

Plantas $40-45 \mathrm{~cm}$ alt., anuais, rizomas ausentes. Lâminas foliares convolutas. Colmos subtriangulares, sulcados longitudinalmente. Brácteas involucrais 2-3, a inferior 2,5-2,8 cm compr., mais longa do que a inflorescência, reflexa ou ereta. Inflorescência formada por uma espiga pseudolateral, ca. $0,7-0,8 \times 0,5 \mathrm{~cm}$, com $50-60$ espiguetas sésseis. Espiguetas unifloras, ca. $3 \times$ 1-1,2 mm, castanhas; gluma externa 3-3,2 $\times 2-2,1$ $\mathrm{mm}$. Estames 3. Estigmas 3-fidos. Aquênio 3-3,5× $0,8-1 \mathrm{~mm}$, com seção transversal pseudolenticular, oblongo, branco.

Material examinado: $20^{\circ} 29^{\prime} 18,5^{\prime \prime} \mathrm{S} 43^{\circ} 41^{\prime} 3,8^{\prime \prime} \mathrm{W}$, 3.XII.2007, fl. e fr., H.M. Longhi-Wagner et al. 10409 (ICN, K, VIC).

Esta espécie corresponde às populações anteriormente identificadas na literatura como $L$. humboldtiana Nees ou L. sellowiana Kunth, de acordo com WCSP (2013), embora a distribuição de L. chinensis seja citada como paleotropical neste website. Adams \& Goetghebeur (1994) e Kearns (1998) citaram L. humboldtiana como pantropical, estendendo-se a regiões subtropicais, em ambientes quentes e úmidos. Por sua vez, $L$. sellowiana tem sido aceita como sinônimo de $L$. humboldtiana por vários autores, como Alves et al. (2013), que não citam $L$. chinensis para o Brasil. Esta é uma questão que necessita ser mais bem estudada para definir a circunscrição de $L$. chinensis e qual o binômio a ser adotado para as populações distribuídas nos Neotrópicos, caso o resultado do estudo deste complexo aponte que $L$. chinensis deva ser aceita com uma circunscrição mais restrita. O nome L. humboldtiana Nees (1834) é referido como ilegítimo no WCSP (2013), porém considera-se que há um problema nomenclatural envolvendo este binômio que deverá ser investigado. Na SOB é pouco comum, sendo encontrada em beira de curso d'água próximo à mata de galeria, a 1390 m.s.m.

\section{Machaerina Vahl}

Plantas perenes, com rizomas. Folhas basilares e dísticas ao longo do colmo, com bainhas e lâminas desenvolvidas, às vezes $1-2$ folhas reduzidas às bainhas, lígula e contralígula ausentes; bainhas com o ápice glabro, não hialino e não marcescente; lâminas planas. Colmos comprimidos ou subcilíndricos. Brácteas involucrais presentes. Inflorescência terminal do tipo paniculódio ou espiciforme, ou espiguetas isoladas em inflorescências laxas ou, ainda, espiguetas reunidas em fascículos congestos dispostos em paniculódios parciais. Espiguetas sésseis ou pediceladas, plurifloras, comprimidas lateralmente, glumas de disposição dística sobre a ráquila. Flores bissexuadas, perigônio representado por 3-6 cerdas perigoniais escabras, ou rudimentares a ausentes; estames 3 ; estigmas 3 -fidos, base do estilete dilatada sobre o fruto e persistente formando um estilopódio triangular e alado, nunca um tubérculo. Aquênio com seção transversal triangular, alado, não envolto por um utrículo, superfície lisa, tuberculada ou transversalmente rugosa (Strong 1997).

Machaerina inclui ca. 25 espécies pantropicais, sendo bastante diversificado na América do Sul, África, Ásia, Malásia e Ilhas do Pacífico (Strong 1997; Acevedo-Rodrigues \& Strong 2005). No Brasil ocorre nas Regiões Sudeste e Sul (Strong 1997). Está representado na SOB por uma espécie. 
8.1. Machaerina ensifolia (Boeck.) T. Koyama, Bot. Mag. 69(812): 63.1956. Fig. 4h

Plantas ca. 1,80-2 $\mathrm{m}$ alt., perenes, rizomas presentes. Bainhas foliares achatadas na base, iridáceas. Lâminas foliares planas, $50-75 \mathrm{~cm} \times$ 5-8 mm, levemente crassas. Inflorescência 10-19 $\mathrm{cm}$ compr., formada por paniculódios parciais congestos, 3-6 $61-1,5 \mathrm{~cm}$, com as espiguetas agrupadas em fascículos. Espiguetas 10-11 × 4-5 $\mathrm{mm}, 4-6$-floras, castanhas, às vezes com tons vináceos, com 1-2 glumas basais vazias. Cerdas perigoniais ausentes. Aquênio não visto.

Material examinado: $20^{\circ} 29^{\prime} 20,1^{\prime \prime} \mathrm{S}, 43^{\circ} 41^{\prime} 18,5^{\prime \prime} \mathrm{W}$, 3.XII.2007, fl., H.M. Longhi-Wagner et al. 10424 (ICN).

Machaerina ensifolia é endêmica do Brasil (Alves et al. 2013), presente em serras das Regiões Sudeste e Sul, de Minas Gerais até Santa Catarina (Strong 1997). Na SOB foi encontrada apenas uma vez, em campos brejosos, formando uma população densa de indivíduos em touceiras bem desenvolvidas, a 1360 m.s.m. As touceiras apresentavam marcas de fogo recente.

\section{Rhynchospora Vahl}

Plantas perenes ou anuais, com ou sem rizomas. Folhas basilares ou distribuídas ao longo do colmo, com bainhas e lâminas desenvolvidas, lígula e contralígula ausentes; bainhas com o ápice glabro, não hialino e não marcescente; lâminas planas, conduplicadas, cilíndricas, subcilíndricas ou filiformes, flácidas ou rígidas. Colmos triangulares, subtriangulares ou cilíndricos. Brácteas involucrais presentes, concentradas no ápice do colmo, nas inflorescências monocéfalas, ou distribuídas ao longo do colmo. Inflorescência do tipo antelódio simples ou composto, paniculódio, ou espiguetas reunidas em 2 ou mais capítulos, ou fascículos congestos terminais e/ou laterais no colmo, ou, ainda, inflorescência monocéfala (capítulo único terminal). Espiguetas sésseis, subsésseis ou pediceladas, plurifloras, cilíndricas, glumas de disposição espiralada, mais raramente dística. Flores bissexuadas, às vezes estaminadas, perigônio representado por cerdas perigoniais escabras ou plumosas, ou perigônio ausente; estames (1)-3(6); estigmas 2-fidos ou indivisos, base do estilete não dilatada sobre o fruto mas persistente formando um estilopódio de formatos variados, geralmente triangular ou piramidal, não alado, nunca um tubérculo. Aquênio com seção transversal lenticular, não alado, não envolto por um utrículo, superfície lisa, tuberculada, papilosa ou transversalmente rugosa (Thomas 1994; Rocha \& Luceño 2002; Araújo et al. 2012).

Rhynchospora inclui ca. 250-300 espécies de regiões tropicais e subtropicais, com maior diversidade na região neotropical (Thomas 1994; Goetghebeur 1998; Rocha \& Luceño 2002; Araújo et al. 2012). Está representado na SOB por 20 espécies.

\section{Chave para espécies de Rhynchospora da Serra do Ouro Branco}

1. Espiguetas sésseis ou, menos comumente, subsésseis. Espiguetas reunidas em 1 (monocéfalas) ou mais capítulos globosos ou hemisféricos.

2. Brácteas involucrais glumiformes, rígidas, mais curtas do que a inflorescência. Cerdas perigoniais plumosas 9.7. Rhynchospora globosa

2'. Brácteas involucrais foliáceas, geralmente mais longas do que a inflorescência. Cerdas perigoniais escabras ou ausentes.

3. Brácteas involucrais totalmente verdes.

4. Plantas $10-18 \mathrm{~cm}$ alt. Lâminas foliares pilosas

9.12. Rhynchospora pilosa

4'. Plantas (25)50-80 cm alt. Lâminas foliares glabras ou escabras.

5. Inflorescência de 4-10 capítulos, agrupados de 1-3 tanto os terminais quanto em cada ramo lateral da inflorescência 9.6. Rhynchospora exaltata

5'. Inflorescencia monocéfala, exclusivamente terminal.

6. Glumas com o ápice recurvado. Um aquênio por espigueta

9.14. Rhynchospora recurvata

6'. Glumas com o ápice reto. Dois ou mais aquênios por espigueta

9.16. Rhynchospora setigera

3'. Brácteas involucrais brancas na base e verdes no ápice.

7. Brácteas involucrais brancas na base apenas na face adaxial. Aquênios 3-5 por espigueta 9.10. Rhynchospora nervosa

7'. Brácteas brancas na base em ambas as faces. Um aquênio por espigueta. 
8. Lâminas foliares planas ou conduplicadas, 1,5-3,5 mm larg. Brácteas involucrais 7-9 9.4. Rhynchospora consanguinea

8'. Lâminas foliares cilíndricas, 0,5-1(-1,1) mm larg. Brácteas involucrais 2-5.

9. Brácteas involucrais 2(3). Bainhas desfeitas em fibras na maturação 9.20. Rhynchospora warmingii

9'. Brácteas involucrais 4-5. Bainhas íntegras na maturação .... 9.1. Rhynchospora albobracteata

1'. Espiguetas todas pediceladas, ou espiguetas curto-pediceladas reunidas em fascículos congestos. Inflorescência em antelódio laxo, terminal ou terminal e laterais ao longo do colmo.

10. Cerdas perigoniais presentes.

11. Cerdas perigoniais 1,6-2,1 mm compr., mais longas do que o aquênio (excluindo o estilopódio). Aquênios 0,8-1 mm larg. Espiguetas 12-30 por fascículo

9.13. Rhynchospora cf. polyantha

11'. Cerdas perigoniais $1(-1,5) \mathrm{mm}$ compr., mais curtas do que o aquênio (excluindo o estilopódio). Aquênios 1,5-2 mm larg. Espiguetas 7-10 por fascículo 9.15. Rhynchospora rugosa

10'. Cerdas perigoniais ausentes.

12. Lâminas foliares cilíndricas e rígidas

9.3. Rhynchospora ciliolata

12'. Lâminas foliares planas ou conduplicadas, flácidas, se rígidas, nunca cilíndricas.

13. Bainhas foliares desfeitas em fibras na maturação.

14. Espiguetas pediceladas em fascículos laxos, castanho-alaranjadas. Aquênios 2 ou mais por espigueta, $0,8-1 \mathrm{~mm}$ compr., levemente rugulosos

9.9. Rhynchospora nardifolia

14'. Espiguetas subsésseis em fascículos congestos, brancas a palhetes. Um aquênio por espigueta, 1,5-1,7 mm compr., liso 9.11. Rhynchospora patuligluma

13'. Bainhas foliares íntegras na maturação.

15. Lâminas foliares velutinas. Espiguetas castanhas com margens brancas

9.19. Rhynchospora velutina

15'. Lâminas glabras, às vezes ciliadas ou escabras nas margens. Espiguetas palhetes ou castanhas sem margens brancas.

16. Plantas $35-55 \mathrm{~cm}$ alt. Aquênios $1,5-1,7 \mathrm{~mm}$ compr.

9.8. Rhynchospora lapensis

16'. Plantas 10-30 cm alt. Aquênios $0,8-1 \mathrm{~mm}$ compr.

17. Plantas $10-15 \mathrm{~cm}$ alt. Aquênios ca. $0,8 \mathrm{~mm}$ compr.

9.18. Rhynchospora tenuis

17'. Plantas $20-30 \mathrm{~cm}$ alt. Aquênios 1-1,2 mm compr.

18. Lâminas foliares ca. $2 \mathrm{~mm}$ larg., subcilíndricas. Estames 3. Espiguetas ca. 0,5 mm larg. ............ 9.5. Rhynchospora emaciata

18'. Lâminas foliares $0,3-0,6 \mathrm{~mm}$ larg, conduplicadas ou filiformes. Estames 1. Espiguetas 0,7-1 mm larg.

19. Antelódios laterais presentes, acompanhando o antelódio terminal. Bráctea involucral 10-16 cm compr. Estilopódio subagudo, base não decurrente sobre o fruto

9.17. Rhynchospora tenella

19'. Antelódio terminal somente. Bráctea involucral 5-7 cm compr. Estilopódio curto-rostrado, base decurrente sobre o fruto 9.2. Rhynchospora brevirostris

9.1. Rhynchospora albobracteata A.C. Araújo, Brittonia 64: 385. $2012 . \quad$ Fig. 4i-j

Plantas $30-50 \mathrm{~cm}$ alt., perenes, rizomas curtos a longos. Folhas basilares, bainhas íntegras na maturação; lâminas foliares cilíndricas, rígidas, $20-25 \mathrm{~cm} \times 0,5-0,7 \mathrm{~mm}$, glabras. Colmos cilíndricos. Brácteas involucrais 4-5, foliáceas, brancas na base, em ambas as faces, e verdes no ápice, a mais inferior 4,9-13,5 cm compr., mais longa do que a inflorescência. Inflorescência terminal monocéfala, hemisférica, $0,5-1 \times 0,5-1$ $\mathrm{cm}$. Espiguetas 5-10, sésseis, 3,5-5 × 1-1,6 mm, 
castanho-vináceas; glumas elíptico-lanceoladas, ápice obtuso. Cerdas perigoniais (0)3, se presentes, escabras, 0,2-0,4 mm compr. Estames 2. Estigmas indivisos. Aquênio 1 por espigueta, 1,2-2 $\times$ 0,6-1,2 mm, obovóide, superfície transversalmente tuberculada, castanho, estilopódio 0,2-0,5 mm compr., triangular, base não decurrente sobre o fruto e totalmente aderida a ele.

Material examinado: 18.IX.1990, fl. R.J.V. Alves \& J. Becker 1469 (ICN, R); 20²9'20'S 4341'47'W, 15.III.2005, fl. e fr., H.M. Longhi-Wagner et al. 9564 (ICN, VIC); 20²9'6,3”S 4342'40,8'W, 8.I.2006, fl., H.M. Longhi-Wagner \& C.C. de Paula 9946 (ICN, VIC).

Rhynchospora albobracteata é endêmica do Brasil, presente nas regiões tropicais e subtropicais, em cerrado, campo rupestre e campos de altitude (Araújo et al. 2012; Alves et al. 2013). Na SOB é pouco comum e foi encontrada em campos brejosos e graminosos quartzíticos, entre 1310 e 1580 m.s.m. Este táxon corresponde às populações tratadas anteriormente como $R$. rigida (Kunth) Boeck. (nome inválido); o novo nome foi proposto por Araújo et al. (2012). Morfologicamente, pode ser confundida com $R$. consanguinea e/ou $R$. warmingii devido à presença de brácteas involucrais foliáceas, brancas na base, em ambas as faces. Rhynchospora consanguinea diferencia-se pela forma e largura da lâmina foliar e maior número de brácteas involucrais. Por sua vez, R. warmingii apresenta um menor número de brácteas involucrais e bainhas desfeitas em fibras, na maturação.

9.2. Rhynchospora brevirostris Griseb., Cat. Pl. Cub. 246. 1866.

Fig. 4k-1

Plantas $20 \mathrm{~cm}$ alt., perenes, rizomas curtos. Folhas basilares e também distribuídas ao longo do colmo, bainhas íntegras na maturação; lâminas foliares conduplicadas ou filiformes, sub-rígidas a flácidas, $12-18 \mathrm{~cm} \times 0,3-0,6 \mathrm{~mm}$, glabras. Colmos cilíndricos, sulcados. Bráctea involucral 1, foliácea, totalmente verde, 5-7 cm compr., mais longa do que a inflorescência. Inflorescência terminal, 0,5-1,5 cm compr., antelódio único, contraído. Espiguetas 2-4 no ápice dos ramos, curtamente pediceladas, 4-4,5 × 0,7-1 mm, castanho-claras; glumas lanceoladas, ápice agudo, reto. Cerdas perigoniais ausentes. Estames 1. Estigmas 2-fidos. Aquênio um por espigueta, ca. $1 \times 0,7 \mathrm{~mm}$, obovóide, superfície transversalmente rugosa, castanho, estilopódio 0,2-0,3 mm compr., deltóide, curto-rostrado, base decurrente sobre o fruto e totalmente aderida a ele.
Material examinado: 19.IV.2008, fl. e fr., F.O.A. Lemes (OUPR 21801).

Rhynchospora brevirostris ocorre na África tropical e Sul, e na América tropical, do México até a Região Sudeste do Brasil, especialmente em cerrado (Araújo 2009a; WCSP 2013). Na SOB é rara, sendo encontrada em campos graminosos quartzíticos. Esta espécie assemelha-se a $R$. tenella na forma e dimensões do aquênio, e quanto às lâminas foliares filiformes. A última distingue-se, principalmente, pela inflorescência com o antelódio terminal acompanhado por 2-3 antelódios laterais, todos laxos, com ramos primários bem visíveis, distribuídos ao longo do colmo, enquanto $R$. brevirostris apresenta apenas um único antelódio, contraído e terminal. Além disto, as duas espécies diferem por características do estilopódio do fruto, como mencionado na chave.

9.3. Rhynchospora ciliolata Boeck., Linnaea 37: 562. 1873. Fig. $4 \mathrm{~m}$

Plantas $25-40 \mathrm{~cm}$ alt., perenes, rizomas curtos. Folhas basilares, bainhas íntegras na maturação; lâminas foliares cilíndricas, rígidas, 20-35 cm $\times 0,5-0,8 \mathrm{~mm}$, glabras. Colmos subcilíndricos. Bráctea involucral 1, foliácea, totalmente verde, 5-12 cm compr., mais longa do que a inflorescência. Inflorescência terminais e/ou laterais, 2-6 cm compr., antelódio de fascículos congestos. Espiguetas 30-70, sésseis ou subsésseis, 5-6 × 1,5-2 mm, castanhoalaranjadas; glumas, lanceoladas, ápice apiculado, reto. Cerdas perigoniais ausentes. Estames 3. Estigmas indivisos. Aquênio 1(-2) por espigueta, 1,3-1,5 × 1,3 mm, obovóide a elipsóide, superfície transversalmente rugosa, alvo, estilopódio $0,3-0,5$ $\mathrm{mm}$ compr., triangular, base não decurrente sobre o fruto e totalmente aderida a ele.

Material examinado: $20^{\circ} 29^{\prime} 20^{\prime} \mathrm{S} 43^{\circ} 41^{\prime} 47^{\prime \prime} \mathrm{W}$, 15.III.2005, fl. e fr., H.M. Longhi-Wagner et al. 9553 a (ICN, VIC); 20³0’18,8”S 43॰38'21'”W, 3.XII.2007, fl., H.M. Longhi-Wagner et al. 10370 (ICN, K, VIC); $20^{\circ} 231$ '31,4”S 4347'10,4”'W, 5.XII.2007, fl., H.M. Longhi-Wagner et al. 10505 (ICN, K, VIC).

Rhynchospora ciliolata é endêmica do Brasil tropical, ocorrendo em caatinga e em cerrado (Alves et al. 2013). Na SOB é pouco comum, sendo encontrada em campos graminosos quartzíticos, entre 1270 e 1320 m.s.m. É facilmente reconhecida por seus fascículos congestos e lâminas foliares cilíndricas e rígidas. 
9.4. Rhynchospora consanguinea (Kunth) Boeck., Linnaea 37: 476. 1873.

Fig. 5a-b

Plantas 20-70 cm alt., perenes, rizomas curtos. Folhas basilares, bainhas íntegras na maturação; lâminas foliares planas ou conduplicadas, flácidas, $14-50 \mathrm{~cm} \times 1,5-3,5 \mathrm{~mm}$, glabras. Colmos cilíndricos. Brácteas involucrais 7-9, foliáceas, brancas na base, em ambas as faces, e verdes no ápice, a mais inferior $6,5-17,5 \mathrm{~cm}$ compr., mais longa do que a inflorescência. Inflorescência terminal monocéfala, hemisférica, $0,5-1,5 \times 0,8-1,5$ $\mathrm{cm}$. Espiguetas 15-30, sésseis, 3,5-5 × 1,5-1,8 mm, castanho-vináceas; glumas oval-lanceoladas, ápice agudo, reto. Cerdas perigoniais 1-6, escabras, $0,2-3 \mathrm{~mm}$ compr. Estames 2. Estigmas indivisos. Aquênio um por espigueta, 1,5-2,5 × 1-1,5 mm, obovóide, superfície transversalmente tuberculada, castanho a amarronzado, estilopódio $0,3-0,8 \mathrm{~mm}$ compr., cônico, base não decurrente sobre o fruto e totalmente aderida a ele.

Material examinado: $20^{\circ} 29^{\prime} 4,2^{\prime \prime} \mathrm{S} 43^{\circ} 42^{\prime} 22,7^{\prime \prime} \mathrm{W}$, 23.III.2004, fl., fr., R.A.X. Borges \& M.R.C. Cota 86 (OUPR); 20²9'20"S 4341'47”'W, 15.III.2005, fl., fr., H.M. Longhi-Wagner et al. 9569 (ICN, VIC); $20^{\circ} 29^{\prime} 14,4$ "S 4341'15,6”'W, 3.XII.2007, fl., H.M. Longhi-Wagner et al. 10390 (ICN, VIC).

Rhynchospora consanguinea está distribuída na Região Neotropical até o sul do Brasil, com limite austral no estado do Paraná, em áreas de cerrado, campo rupestre e campos de altitude (Araújo et al. 2012). Na SOB foi encontrada em campos brejosos e em campos graminosos quartzíticos, a 1480 m.s.m. Esta espécie é frequentemente confundida com $R$. albobracteata a qual difere pelo menor número de brácteas involucrais e pela estrutura das lâminas foliares.

9.5. Rhynchospora emaciata (Nees) Boeck., Vidensk. Meddel. Naturhist. Foren. Kjøbenhavn 31: 149. 1870.

Fig. 5c-e

Plantas $20-30 \mathrm{~cm}$ alt., perenes, rizomas curtos. Folhas basilares e também distribuídas ao longo do colmo, bainhas íntegras na maturação; lâminas foliares subcilíndricas, flácidas, ca. 15-20 $\mathrm{cm} \times 2 \mathrm{~mm}$, glabras. Colmos triangulares. Bráctea involucral 1 , foliácea, totalmente verde, 4-6 $\mathrm{cm}$ compr., mais longa do que a inflorescência. Inflorescência terminal e lateral, $2,5-5 \mathrm{~cm}$ compr., antelódio em fascículos laxos. Espiguetas 1-2 agrupadas, pediceladas, ca. $3-3,5 \times 0,5 \mathrm{~mm}$, castanhas; glumas lanceoladas, ápice apiculado a aristulado, reto. Cerdas perigoniais ausentes. Estames 3. Estigmas 2-fidos. Aquênio 1-2 por espigueta, ca. $1 \times 0,7 \mathrm{~mm}$, oblongo a ligeiramente obovóide, superfície transversalmente rugulosa, castanho a marrom, estilopódio $0,2-0,4 \mathrm{~mm}$ compr., deltóide, base não decurrente sobre o fruto $\mathrm{e}$ totalmente aderida a ele.

Material examinado: $20^{\circ} 28^{\prime} 51,4^{\prime \prime} \mathrm{S} 43^{\circ} 43^{\prime} 11,4^{\prime \prime} \mathrm{W}$, 9.I.2006, fl., H.M. Longhi-Wagner \& C.C. de Paula 10042 (ICN, VIC).

Material adicional: MINAS GERAIS: São Roque de Minas, 23.XI.1995, fl. e fr., J. Nakajima et al. 1601 (K).

Rhynchospora emaciata ocorre na América do Sul, presente em todas as regiões do Brasil, especialmente em cerrado e campo rupestre (Thomas 1998; Rocha \& Luceño 2002). Na Serra do Ouro Branco foi encontrada em campos brejosos, a 1450 m.s.m., sendo pouco comum. Esta espécie foi aceita como subespécie de $R$. tenuis Link (Simpson 1995), com a qual pode ser confundida no campo. Rhynchospora emaciata apresenta maior porte e inflorescência mais laxa do que $R$. tenuis, além de espiguetas mais delicadas e glumas mais longas do que largas, quando comparadas às de $R$. tenuis.

9.6. Rhynchospora exaltata Kunth, Enum. P1. 2: 291. 1837.

Fig. 5f-h

Plantas ca. $80 \mathrm{~cm}$ alt., perenes, rizomas longos. Folhas caulinares, bainhas íntegras na maturação; lâminas foliares planas, rígidas, 25-45 $\mathrm{cm} \times 4,5-6 \mathrm{~mm}$, fortemente escabras. Colmos triangulares. Bráctea involucral 1, precedendo cada capítulo da inflorescência, foliácea, totalmente verde, $11-25 \mathrm{~cm} \times 3-5 \mathrm{~mm}$, geralmente mais curta do que a inflorescência. Inflorescência terminal e lateral, 25-40 cm compr., antelódios de 1-3 capítulos globosos, em cada ramo. Espiguetas ca. 50 por capítulo, sésseis ou subsésseis, ca. (4-) 4,6-5 $\times 0,8 \mathrm{~mm}$, castanho-claras; glumas lanceoladas, as basais com ápice mucronado, múcron ca. 0,2 $\mathrm{mm}$, reto. Cerdas perigoniais ausentes. Estames 3. Estigmas curtamente bífidos. Aquênio 1(2) por espigueta, ca. 1,5 × 1,3 mm, elipsóide, superfície transversalmente rugulosa, castanho-alaranjado, estilopódio ca. $0,5 \mathrm{~mm}$ compr., cônico, base não decurrente sobre o fruto e totalmente aderida a ele. Material examinado: 9.X.1962, fl. e fr., V.A. Araújo (OUPR 22465); 1.I.1988, fl. e fr., M.E.N. Lago (BHCB 14454); 11.VII.1996, fl., R.J. Alves \& J. Becker 5431 (ICN, R); 2.X.2009, fl. e fr., N.G. da Silva 392 (R); 20.VIII.2007, fl., F.O.A. Lemes s.n. (OUPR 12443); $20^{\circ} 29^{\prime} 18,5^{\prime}$ 'S $43^{\circ} 41^{\prime} 3,8^{\prime \prime} \mathrm{W}, 3 . X I I .2007$, fr., H.M. Longhi-Wagner et al. 10413 (ICN, VIC); 20²9'18”S $43^{\circ} 41^{\prime} 50^{\prime}$ W, fl., D.P. Saraiva et al. 192 (RB).

Material adicional: MINAS GERAIS: Viçosa, 18.VII.1930, fl. e fr., Y.E.J. Mexia 4867 (K). 


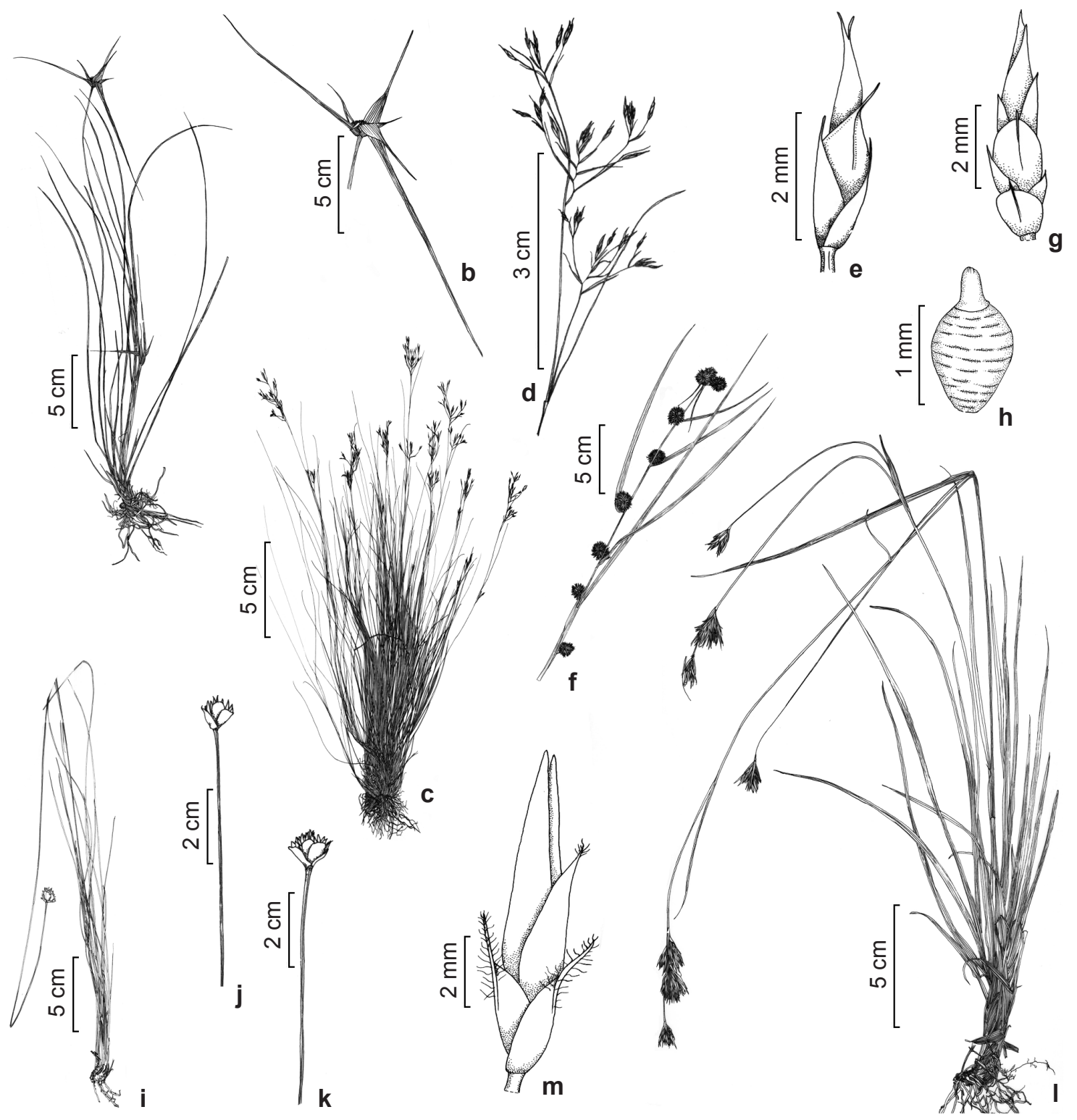

Figura 5 -a-b. Rhynchospora consanguinea - a. hábito; b. inflorescência. c-e. R. emaciata - c. hábito; d. inflorescência; e. espigueta. f-h. R. exaltata - f. inflorescência; g. espigueta; h. aquênio. i-k. R. globosa - i. hábito; j. padrão da inflorescência; k. variação na inflorescência. 1-m. R. lapensis - 1. hábito; m. espigueta (a-b H.M. Longhi-Wagner \& C.C. de Paula 9569; c-e H.M. Longhi-Wagner \& C.C. de Paula 10042; f-h M.E.N. Lago s.n. - BHCB 14454; i-k H.M. Longhi-Wagner \& C.C. de Paula 10005; 1-m H.M. Longhi-Wagner \& C.C. de Paula 9998).

Figure 5 - a-b. Rhynchospora consanguinea - a. habit; b. inflorescence. c-e. R. emaciata - c. habit; d. inflorescence; e. spikelet. f-h. $R$. exaltata - f. inflorescence; g. spikelet; h. achene. i-k. R. globosa - i. habit; j. inflorescence; k. inflorescence variation. 1-m. R. lapensis -1. habit; m. spikelet (a-b H.M. Longhi-Wagner \& C.C. de Paula 9569; c-e H.M. Longhi-Wagner \& C.C. de Paula 10042; f-h M.E.N. Lago s.n. - BHCB 14454; i-k H.M. Longhi-Wagner \& C.C. de Paula 10005; 1-m H.M. Longhi-Wagner \& C.C. de Paula 9998).

Rhynchospora exaltata foi referida para Cuba e América do Sul tropical e subtropical (Thomas 1994, 1998) e está presente em todas as regiões do Brasil (Araújo 2009a). Na SOB foi encontrada em local úmido de beira e interior de mata e no campo quartzítico, entre afloramentos, entre 1050 e 1390 m.s.m. As plantas desta espécie apresentam, caracteristicamente, espiguetas reunidas em vários capítulos ao longo do colmo, o que permite a sua identificação no campo. 
9.7. Rhynchospora globosa (Kunth) Roem. \& Schult., Syst. Veg. 2: 89. $1817 . \quad$ Fig. 5i-k

Plantas 50-70 cm alt., perenes, rizomas curtos.

Folhas basilares, bainhas íntegras na maturação; lâminas foliares conduplicadas, flácidas, 20-30 $\mathrm{cm} \times 0,7-1 \mathrm{~mm}$, glabras. Colmos cilíndricos ou subtriangulares. Brácteas involucrais 4-6, glumiformes, rígidas, palhetes, a inferior ca. $7 \mathrm{~mm}$ compr., todas mais curtas do que a inflorescência. Inflorescência terminal monocéfala, globosa ou hemisférica, ca. 1-1,5 × $1 \mathrm{~cm}$. Espiguetas 30-40, sésseis, $6,5-8 \times 1,5-2 \mathrm{~mm}$, palhetes; glumas elíptico-lanceoladas, ápice agudo, reto. Cerdas perigoniais 6 , plumosas, 2-2,7 mm compr., tão ou mais longas do que o aquênio. Estames 2. Estigmas indivisos. Aquênio 1 por espigueta, 1,5-3 $\times 0,8-1,6 \mathrm{~mm}$, obovóide, superfície lisa, castanho, estilopódio 0,4-0,6 $\mathrm{mm}$ compr., piramidal, base não decurrente sobre o fruto, presa a ele apenas por um ponto central.

Material examinado: 18.IV.1990, fl., R.J. Alves \& $J$. Becker 1472 (ICN, R); 20²9'6,5”S 4342'39,7”W, fl., 8.I.2006, H.M. Longhi-Wagner \&. C.C. de Paula 9959 (ICN, VIC); $20^{\circ} 30^{\prime} 24,9^{\prime \prime}$ S 433'ㄱ'47,3”'W, 9.I.2006, fl. e fr., H.M. Longhi-Wagner \& C.C. de Paula 10005 (ICN, VIC); $20^{\circ} 28^{\prime} 16,8^{\prime}$ "S $43^{\circ} 43^{\prime} 48,5^{\prime \prime} \mathrm{W}, 4 . X I I .2007$, fl. e fr., H.M. Longhi-Wagner et al. 10471 (ICN).

Rhynchospora globosa está amplamente distribuída na Região Neotropical, ocorrendo em áreas subtropicais, presente em todas as regiões do Brasil, em cerrado, campo rupestre e campos de altitude (Araújo et al. 2012). Na SOB é pouco comum, sendo encontrada em campos graminosos quartzíticos de encosta com relativa umidade, e em beira de córrego, entre 1210 e 1560 m.s.m. Espécie facilmente identificada pela inflorescência monocéfala precedida de brácteas glumiformes rígidas.

9.8. Rhynchospora lapensis C.B. Clarke, Bull. Misc. Inform., Addit. Ser. 8: 38. 1908. Fig. 51-m

Plantas $35-55 \mathrm{~cm}$ alt., rizomas curtos. Folhas basilares, bainhas íntegras na maturação; lâminas foliares planas, flácidas, $10-20 \mathrm{~cm} \times 3-3,5 \mathrm{~mm}$, ciliadas nas margens. Colmos triangulares. Bráctea involucral 1, foliácea, $8-12 \mathrm{~cm}$ compr., mais longa do que a inflorescência. Inflorescência terminal e lateral, 5-10 cm compr., antelódio de fascículos congestos. Espiguetas 10-20, sésseis ou subsésseis, (9-)10-12 × 1,5 mm, palhetes; glumas floríferas lanceoladas, ápice agudo, reto. Cerdas perigoniais ausentes. Estames 2. Estigmas indivisos. Aquênio um por espigueta, $1,5-1,7 \times 1,2-1,5 \mathrm{~mm}$, obovóide a piriforme, superfície transversalmente rugosa, palhete, estilopódio ca. $0,5 \mathrm{~mm}$ compr., triangular, base não decurrente sobre o fruto e totalmente aderida a ele.

Material examinado: 2.X.1988, fl. e fr., V.S. da Silva (BHCB 14171); 20²9'4,2”S 4342'22,7'”, 23.III.2004,

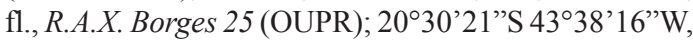
15.III.2005, fl., H.M. Longhi-Wagner et al. 9548 (ICN, VIC); $20^{\circ} 30^{\prime} 20,3$ ”'S $43^{\circ} 37^{\prime} 53,9$ ”'W, 9.I.2006, fl. e fr., H.M. Longhi-Wagner \& C.C. de Paula 9998 (ICN, VIC); $20^{\circ} 30^{\prime} 28,4^{\prime \prime}$ 'S 4337'29,4”'W, 5.XII.2007, fl. e fr., H.M. Longhi-Wagner et al. 10494 (ICN, K, VIC).

Rhynchospora lapensis é endêmica do Brasil tropical, em cerrado e campo rupestre, porém, foi referida como não endêmica por Alves et al. (2013). $\mathrm{Na} \mathrm{SOB}$ é comum e foi encontrada em campos graminosos quartzíticos e em solos arenosos entre afloramentos rochosos, entre 1230 e 1560 m.s.m. Este táxon corresponde aos espécimes comumente identificados em herbário como $R$. riedeliana C.B. Clarke. A coleção Riedel 958 é o holótipo de $R$. lapensis, embora esteja citada erroneamente em Jstor (2013) como material tipológico de $R$. riedeliana C.B. Clarke. O holótipo desta última é uma outra coleção (Riedel 2992) proveniente da Serra do Itacolomi, Minas Gerais (Clarke 1908). Entende-se que a citação errônea da coleção Riedel 958 como tipo de $R$. riedeliana contribuiu para uma confusão nomenclatural responsável pelos erros de identificação de materiais de $R$. lapensis. Embora ambos estes nomes sejam aceitos como espécies independentes tanto por Alves et al. (2013) quanto por Goverts et al. (2013), a identidade de $R$. riedeliana permanece incerta.

9.9. Rhynchospora nardifolia (Kunth) Boeck., Linnaea 37: 560. 1873. Fig. 6a-d

Plantas 20-30 cm alt., perenes, rizomas curtos. Folhas basilares, bainhas desfeitas em fibras, na maturação; lâminas foliares conduplicadas, flácidas, $10-20 \mathrm{~cm} \times 0,5-1 \mathrm{~mm}$, glabras. Colmos triangulares. Bráctea involucral 1, foliácea, totalmente verde, $12-15 \mathrm{~cm}$ compr., mais longa do que a inflorescência. Inflorescência terminal e lateral 7-12 cm compr., antelódio de fascículos laxos. Espiguetas 3-5, pediceladas, 5,5-6 × 1-1,3 $\mathrm{mm}$, variegadas, castanho-alaranjadas; glumas oval-lanceoladas, ápice apiculado, reto. Cerdas perigoniais ausentes. Estames 3. Estigmas indivisos. Aquênios 2 ou mais por espigueta, ca. $0,8-1 \times 1$ $\mathrm{mm}$, elipsóides, superfície levemente rugulosa transversalmente, acinzentados, estilopódio 0,2-0,3 $\mathrm{mm}$ compr., obtuso, base não decurrente sobre o fruto e totalmente aderida a ele. 


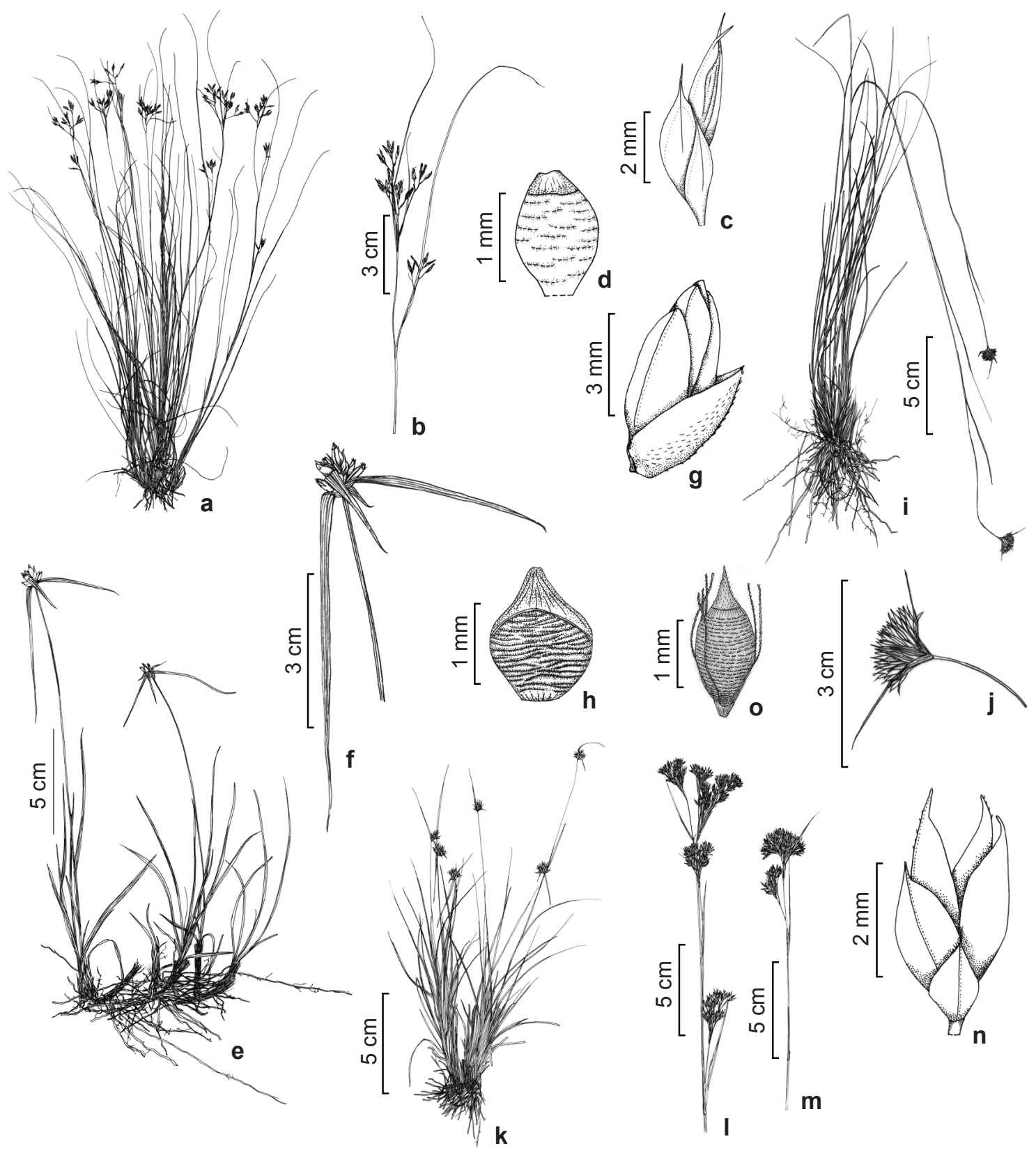

Figura 6 - a-d. Rhynchospora nardifolia - a. hábito; b. inflorescência; c. espigueta; d. aquênio. e-h. R. nervosa - e. hábito; f. inflorescência; g. espigueta; h. aquênio. i-j. R. patuligluma - i. hábito; j. inflorescência. k. R. pilosa - hábito. 1-o. R. cf. polyantha - 1. padrão da inflorescência; $\mathrm{m}$. variação da inflorescência; n. espigueta; o. aquênio (a-d H.M. Longhi-Wagner \& C.C. de Paula 9950; e-h H.M. Longhi-Wagner et al. 10492; i-j H.M. Longhi-Wagner et al. 10386; k H.M. Longhi-Wagner \& C.C. de Paula 9955; 1-o H.M. Longhi-Wagner \& C.C. de Paula 10021).

Figure 6 - a-d. Rhynchospora nardifolia - a. habit; b. inflorescence; c. spikelet; d. achene. e-h. R. nervosa-e. habit; f. inflorescence; g. spikelet; h. achene. i-j. R. patuligluma - i. habit; j. inflorescence. k. R. pilosa-habit. 1-o. R. cf. polyantha-1. inflorescence; m. inflorescence variation; n. spikelet; o. achene (a-d H.M. Longhi-Wagner \& C.C. de Paula 9950; e-h H.M. Longhi-Wagner et al. 10492; i-j H.M. Longhi-Wagner et al. 10386; k H.M. Longhi-Wagner \& C.C. de Paula 9955; 1-o H.M. Longhi-Wagner \& C.C. de Paula 10021). 
Material examinado: $20^{\circ} 29^{\prime} 6,3^{\prime \prime} \mathrm{S} 43^{\circ} 42^{\prime} 40,8^{\prime \prime} \mathrm{W}$, 8.I.2006, fl. e fr., H.M. Longhi-Wagner \& C.C. de Paula 9950 (ICN, VIC); 20³0'22"S 4337'59,3”W, 2.XII.2007, fl., H.M. Longhi-Wagner et al. 10331 (ICN, K); 20³0'19,2"S 4340'5,2'"W, 3.XII.2007, fl., H.M. Longhi-Wagner et al. 10383 (ICN, K); 20²9'22,9'S 4341'13,8'W, 3.XII.2007, fl., H.M. Longhi-Wagner et al. 10414 (ICN, K); 20²9'18,1"S 4343'12,8"W, 4.XII.2007, fl., H.M. Longhi-Wagner et al. 10449 (ICN, K); 20²9'14,5”S 4341'13,9'”, 3.XII.2007, fl. e fr., H.M. Longhi-Wagner et al. 10401 (ICN, VIC); 20³0'29,9'S 4337'47,3”W, 5.XII.2007, fl., H.M. Longhi-Wagner et al. 10488 (ICN, VIC).

Rhynchospora nardifolia ocorre nas regiões tropicais e subtropicais da América do Sul, em cerrado e campo rupestre (Rocha \& Luceño 2002). $\mathrm{Na} \mathrm{SOB}$ foi encontrada em campos graminosos quartzíticos úmidos de encosta, localmente comum e, menos comumente, em solos ferruginosos, entre 1260 e 1580 m.s.m. Espécie semelhante a $R$. emaciata pelas lâminas foliares e inflorescência em fascículos laxos, diferenciando-se pelas bainhas desfeitas em fibras, na maturação, enquanto permanecem íntegras em $R$. emaciata.

9.10. Rhynchospora nervosa (Vahl) Boeck., Vidensk. Meddel. Dansk Naturhist. Foren. Kjøbenhavn 143.1869.

Fig. 6e-h

Plantas 15-20 (-25) cm alt., perenes, rizomas longos. Folhas basilares, bainhas íntegras na maturação; lâminas foliares planas, flácidas, ca. 8-10 cm × 1,7 mm, glabras. Colmos cilíndricos a lenticulares. Brácteas involucrais 4-5, foliáceas, brancas na base apenas na face adaxial, e verdes no ápice, a inferior $4-8 \mathrm{~cm}$ compr., mais longa do que a inflorescência. Inflorescência terminal monocéfala, hemisférica $1-1,2 \times 0,6-0,8 \mathrm{~cm}$. Espiguetas 5-15, sésseis, 5,5-6 × 1,7-2 mm, brancas; glumas elíptico-lanceoladas, ápice reto. Cerdas perigoniais ausentes. Estames 3. Estigmas 2-fidos. Aquênios 3-5 por espigueta, ca. 1,2-1,7 $\times 1 \mathrm{~mm}$, suborbicular, superfície transversalmente rugosa, palhete a castanho, estilopódio 0,5-0,6 mm compr., triangular, base não decurrente sobre o fruto e totalmente aderida a ele.

Material examinado: $20^{\circ} 30^{\prime} 22,5^{\prime} \mathrm{S} 43^{\circ} 37^{\prime} 59,3$ 'W, 2.XII.2007, fl., H.M. Longhi-Wagner et al. 10343 (ICN); 20³0'28,4”S 4337'29,4'W, 5.XII.2007, fl., H.M. Longhi-Wagner et al. 10492 (ICN, K).

Material adicional: ESPÍRITO SANTO: Guarapari, 25.I.1964, fl. e fr., F.O. Hoehne 5536 (ICN, VIC).

Rhynchospora nervosa ocorre desde o México até o nordeste da Argentina (Thomas 1994, 1998) e no Brasil tropical (Alves et al. 2013). Na SOB foi encontrada em campos graminosos quartzíticos, entre 1230 e 1270 m.s.m. Rhynchospora nervosa compartilha caracteres morfológicos com $R$. pubera (Vahl) Boeck. (sem registro para a SOB), a qual se diferencia pelas folhas mais longas do que o colmo, brácteas totalmente verdes, espiguetas amarronzadas quando maduras e, em geral, aquênio mais largos do que longos (Strong 2006).

9.11. Rhynchospora patuligluma C.B.Clarke ex Lindm., Bih. Kongl. Svenska Vetensk.-Akad. Handl. 26(9): 25. 1900.

Fig. 6i-j

Plantas 40-45 cm alt., perenes, rizomas curtos. Folhas basilares, bainhas desfeitas em fibras, na maturação; lâminas foliares planas, às vezes convolutas quando secas, flácidas, 18-22 $\mathrm{cm} \times 1-1,2 \mathrm{~mm}$, escabriúsculas na face ventral. Colmos cilíndricos. Brácteas involucrais 2-3, foliáceas, verdes com margens hialinas, na metade inferior, verdes no ápice, a mais inferior 1,5-2 cm compr., mais longa do que a inflorescência. Inflorescência terminal, $0,5-0,8(-1) \times 0,7-1$ $\mathrm{cm}$, antelódio em fascículos congestos, 1-2 no ápice dos ramos. Espiguetas 30-50, subsésseis, 4-5 × 1,5-2 mm, brancas a palhetes; glumas lanceoladas, mucronadas, ápice reto. Cerdas perigoniais ausentes. Estames 3. Estigmas inteiros ou brevemente bífidos. Aquênio 1 por espigueta, 1,5-1,7 × 1-1,2 mm, elíptico, superfície lisa, branco a acinzentado; estilopódio 0,7-1 $\mathrm{mm}$ compr., triangular, base não decurrente sobre o fruto e totalmente aderida a ele.

Material examinado: $20^{\circ} 30^{\prime} 18,9$ "S $43^{\circ} 36^{\prime} 28,6$ "W, 8.V.2004, fl., R.A.X. Borges 5 (OUPR); 20³0'18,8”S 4338'21'W, 3.XII.2007, fl. e fr., H.M. Longhi-Wagner et al. 10386 (ICN).

Rhynchospora patuligluma é citada para a Bolívia e Brasil, neste último ocorrendo em vegetação de cerrado nas Regiões Sudeste e Centro-Oeste (Alves et al. 2009). Na SOB é pouco comum e foi encontrada em campos graminosos quartzíticos, entre afloramentos rochosos, e em campo sujo, próximo à mata de galeria, entre 1110 e 1360 m.s.m. Materiais desta espécie eram anteriormente identificados em herbário como R. pallida (Nees) Steud., atualmente aceita na sinonímia de $R$. patuligluma (WCSP 2013).

9.12. Rhynchospora pilosa (Kunth) Boeck., Linnaea 37:537. 1873. Fig. 6k

Plantas $10-18 \mathrm{~cm}$ alt., perenes, rizomas curtos. Folhas basilares, bainhas desfeitas em fibras na maturação; lâminas foliares planas, flácidas, 
$7-8 \mathrm{~cm} \times 0,6-1 \mathrm{~mm}$, pilosas. Colmos triangulares. Brácteas involucrais 2(-3), foliáceas, totalmente verdes, a mais inferior $2-4 \mathrm{~cm}$ compr., mais longa do que a inflorescência. Inflorescência terminal monocéfala, hemisférica, ca. $0,7-0,8 \times 0,5 \mathrm{~cm}$. Espiguetas 10-20, sésseis a subsésseis, ca. 6-7 × $1,5 \mathrm{~mm}$, palhetes; glumas oval-lanceoladas, ápice agudo, reto. Cerdas perigoniais ausentes. Estames 2. Estigmas indivisos. Aquênio 1 por espigueta, ca. 1,6 $\times 1 \mathrm{~mm}$, obovóide, superfície tuberculada, palhete, estilopódio $0,2-0,3 \mathrm{~mm}$ compr., triangular, base não decurrente sobre o fruto e totalmente aderida a ele. Material examinado: $20^{\circ} 29^{\prime} 6,5^{\prime \prime} \mathrm{S} 43^{\circ} 42^{\prime} 39,7^{\prime} \mathrm{W}$, 8.I.2006, fl. e fr., H.M. Longhi-Wagner \& C.C. de Paula 9955 (ICN, VIC).

Rhynchospora pilosa é nativa da América do Sul tropical, referida para a Venezuela, Guiana Inglesa e Brasil, em cerrado, campo rupestre e em encraves de cerrado da Região Amazônica (Strong 2006, WCSP 2013). Na SOB é pouco comum e foi encontrada em campos graminosos quartzíticos de encosta, com pouca umidade, a 1560 m.s.m. Planta com inflorescência monocéfala semelhante à $R$. globosa, porém esta última difere pelas brácteas foliares glumiformes e rígidas e lâminas foliares glabras.

9.13. Rhynchospora cf. polyantha Steud., Syn. Pl. Glumac. 2: 147. $1855 . \quad$ Fig. 61-n

Plantas 50-60 cm alt., perenes, rizomas curtos. Folhas basilares e também distribuídas ao longo do colmo, bainhas íntegras na maturação; lâminas foliares planas, flácidas, $15-20 \mathrm{~cm} \times 1,5-1,8 \mathrm{~mm}$, glabras. Colmos triangulares. Brácteas involucrais 1-2, foliáceas, totalmente verdes, a mais inferior $4 \mathrm{~cm}$ compr., mais curta do que a inflorescência. Inflorescência terminal e lateral, $8-10 \mathrm{~cm}$ compr., antelódio em fascículos congestos. Espiguetas 12-30 por fascículo, subsésseis ou pediceladas, 4-5,5 × 1,5-2 mm, castanho-amarronzadas; glumas elípticolanceoladas, ápice atenuado, reto a levemente curvo. Cerdas perigoniais 6, escabras, 1,6-2,1 mm compr. Estames 2. Estigmas 2-fidos. Aquênios 2-3 por espigueta, 1,3-2,1 ×0,8-1 mm, elipsóide, superfície transversalmente rugosa, palhete, estilopódio 0,5-0,7 mm compr., triangular, base não decurrente sobre o fruto e totalmente aderida a ele.

Material examinado: $20^{\circ} 28^{\prime} 51,4^{\prime \prime} \mathrm{S} 43^{\circ} 43^{\prime} 11,4^{\prime \prime} \mathrm{W}$, 9.I.2006, fl. e fr., H.M. Longhi-Wagner \& C.C. de Paula 10021 (ICN, VIC).

Rhynchospora polyantha está presente na América do Sul tropical, Peru e Brasil (WCSP 2013). No Brasil ocorre na Região Centro-Oeste até a Região Sul, em vegetação de cerrado e campos de altitude (dados das autoras). O material da SOB aceito como $R$. cf. polyantha é comum na área em que foi encontrado, em campos brejosos, a 1450 m.s.m. O material coletado na SOB apresenta características intermediárias entre Rhynchospora marisculus Lindl. \& Nees e R. rugosa (Vahl) Gale. As espécies mais comuns da seção Rugosae (= Glaucae) no Estado de Minas Gerais são R. rugosa, $R$. marisculus e $R$. brasiliensis Boeck. A coleção H.M. Longhi-Wagner \& C.C. de Paula 10021 não confere com a circunscrição de nenhuma das espécies acima, mas é morfologicamente semelhante a espécimes identificados como $R$. polyantha nos herbários HBR e ICN. No entanto, Guaglianone (1979) distinguiu $R$. polyantha de R. rugosa por ter uma inflorescência "pauciespiculada", ao contrário do que foi observado no material estudado. Sendo assim, optou-se por identificar o exemplar como $R$. cf. polyantha.

9.14. Rhynchospora recurvata (Nees) Steud., Syn. Pl. Glumac. 2: 145. $1855 . \quad$ Fig. 7a-d

Plantas (25-)50-70 cm alt., perenes, rizomas curtos. Folhas basilares, bainhas íntegras na maturação; lâminas foliares conduplicadas, raramente planas, rígidas, $(20-) 30-40 \mathrm{~cm} \times 0,7-1$ $\mathrm{mm}$, glabras. Colmos cilíndricos a subtriangulares. Brácteas involucrais 3, foliáceas, totalmente verdes, a mais inferior 7-14 cm compr., mais longa do que a inflorescência. Inflorescência terminal monocéfala, globosa, 1,5 × 1,5-2 cm. Espiguetas 70-100, sésseis, 4-4,5 × 0,8-1,2 mm, palhetes; glumas largamente elípticas, ápice apiculado, fortemente recurvado. Cerdas perigoniais ausentes. Estames 3 . Estigma indiviso. Aquênio 1 por espigueta, 1,5-3 $\times$ 0,8-1,6 mm, elipsóide, superfície transversalmente rugosa, palhete a esbranquiçado; estilopódio ca. 0,5 $\mathrm{mm}$ compr., triangular, base não decurrente sobre o fruto e presa a ele apenas por um ponto central. Material examinado: 2.X.1988, fl. e fr., G.S. Resende (BHCB 14144); 17.IX.1990, fl. e fr., R.J. Alves \& J. Becker 1442 (ICN, R); 2029'S 434W, 24.VII.1987, fl. e fr., R. Mello-Silva et al., CFCR 11213 (SPF); 20²9'6,5”S 4342'39,7’'W, 8.I.2006, fl. e fr., H.M. Longhi-Wagner \& C.C. de Paula 9965 (ICN, VIC); 20²9'6,5”S

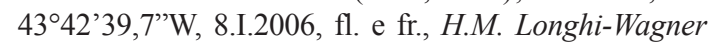
\& C.C. de Paula 9973 (ICN, VIC); 20³0'19,6”'S $43^{\circ} 37^{\prime} 56,8^{\prime}$ 'W, 9.I.2006, fl., H.M. Longhi-Wagner \& C.C. de Paula 9985 (ICN, VIC); 20³0'19,4'S 4337'56,1'”, 2.XII.2007, fl., H.M. Longhi-Wagner et al. 10452 (ICN, VIC); $20^{\circ} 29^{\prime} 7,2^{\prime \prime}$ 'S $43^{\circ} 43^{\prime} 22,7^{\prime \prime}$ W, 4.XII.2007, fl., H.M. Longhi-Wagner et al. 10360 (ICN, K, VIC). 


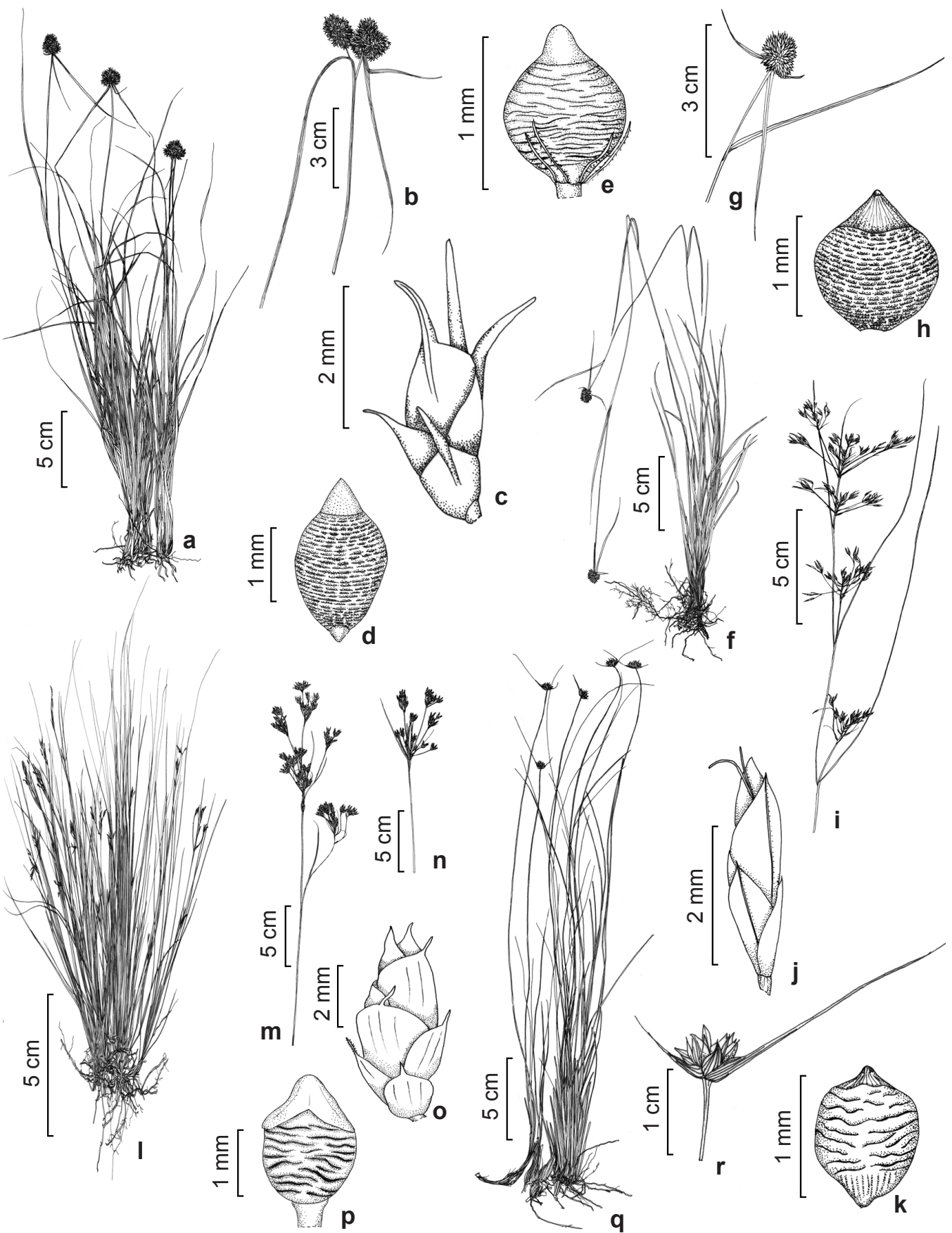

Figura 7 - a-d. Rhynchospora recurvata - a. hábito; b. inflorescência; c. espigueta; d. aquênio. e. $R$. rugosa - aquênio. f-h. $R$. setigera -f. hábito; g. inflorescência; h. aquênio. i-k. R. tenella -i. inflorescência; j. espigueta; k. aquênio. 1. R. tenuis - hábito. $\mathrm{m}$-p. R.velutina $-\mathrm{m}$. inflorescência; $\mathrm{n}$. variação da inflorescência; o. espigueta; $\mathrm{p}$. aquênio. q-r. $R$. warmingii - q. hábito; $\mathrm{r}$. inflorescência (a-d H.M. Longhi-Wagner \& C.C. de Paula 9965; e H.M. Longhi-Wagner et al. 10330; f-g H.M. Longhi-Wagner et al. 10403; h A.C. Araújo \& G. Silveira 1596; i-k H.M. Longhi-Wagner \& C.C. de Paula 9549; 1 H.M. Longhi-Wagner et al. 10463; m-n H.M. Longhi-Wagner \& C.C. de Paula 10033; o-p S. Romaniuc 458; q-r H.M. Longhi-Wagner et al. 10344). Figure 7 - a-d. Rhynchospora recurvata - a. habit; b. inflorescence; c. spikelet; d. achene. e. R. rugosa - achene. f-h. R. setigera - f. habit; g. inflorescence; $\mathrm{h}$. achene. $\mathrm{i}-\mathrm{k}$. R. tenella $\mathrm{-i}$. inflorescence; $\mathrm{j}$. spikelet; $\mathrm{k}$. achene. 1 . R. tenuis - habit. $\mathrm{m}-\mathrm{p}$. R.velutina $-\mathrm{m}$. inflorescence; $\mathrm{n}$. inflorescence variation; o. spikelet; p. achene. q-r. R. warmingii - q. habit; r. inflorescence (a-d H.M. Longhi-Wagner \& C.C. de Paula 9965; e H.M. Longhi-Wagner et al. 10330; f-g H.M. Longhi-Wagner et al. 10403; h A.C. Araújo \& G. Silveira 1596; i-k H.M. Longhi-Wagner \& C.C. de Paula 9549; 1 H.M. Longhi-Wagner et al. 10463; m-n H.M. Longhi-Wagner \& C.C. de Paula 10033; o-p S. Romaniuc 458; q-r H.M. Longhi-Wagner et al. 10344). 
Rhyncospora recurvata é endêmica do Brasil, predominante no cerrado (Alves et al. 2013). $\mathrm{Na}$ SOB é comum em campos graminosos quartzíticos com afloramentos rochosos, sobre e entre as rochas, entre 1100 e 1560 m.s.m. Os indivíduos de $R$. recurvata geralmente apresentam lâminas foliares conduplicadas. Entretanto, no espécime H.M. Longhi-Wagner \& C.C. de Paula 9965, as lâminas são planas.

9.15. Rhynchospora rugosa (Vahl) Gale Rhodora 46: 275.1944.

Fig. $7 \mathrm{e}$

Plantas $50-75 \mathrm{~cm}$ alt., perenes, rizomas curtos. Folhas basilares, com 1-2 distribuídas ao longo do colmo, bainhas íntegras na maturação; lâminas foliares planas, convolutas quando maduras, flácidas, $15-25 \mathrm{~cm} \times 3,5-4 \mathrm{~mm}$, glabras. Colmos triangulares. Bráctea involucral 1, foliácea, verde, ca. $4 \mathrm{~cm}$ compr., mais curta do que a inflorescência. Inflorescência terminal e lateral, (3)20 cm compr., antelódio em fascículos congestos. Espiguetas 7-10 por fascículo, curto-pediceladas, 3,5-4 × 1,5-2 mm, castanho-amarronzadas; glumas elíptico-lanceoladas, ápice mucronado, reto. Cerdas perigoniais 6 , escabras, $1(-1,5) \mathrm{mm}$ compr. Estames 3. Estigmas 2-fidos. Aquênio 1 por espigueta, 1,5-2 × 1-1,5 mm, elipsóide, superfície transversalmente rugulosa, castanho, estilopódio $0,5-0,6 \mathrm{~mm}$ compr., triangular, base não decurrente sobre o fruto e totalmente aderida a ele.

Material examinado: $20^{\circ} 30^{\prime} 22^{\prime \prime} \mathrm{S} 43^{\circ} 37^{\prime} 59,3$ ' W, 2.XII.2007, fr., H.M. Longhi-Wagner et al. 10330 (ICN, K); $20^{\circ} 29^{\prime} 20,1^{\prime \prime S} 43^{\circ} 41^{\prime} 18,5^{\prime \prime}$ W, 3.XII.2007, fl., H.M. Longhi-Wagner et al. 10429 (ICN, K).

Rhynchospora rugosa ocorre desde o México até a Argentina, em vegetação de cerrado, campo rupestre, campos baixos e campos de altitude (Guaglianone 1979). Na SOB é comum e foi encontrada em campos graminosos quartzíticos e em campos brejosos, entre 1280 e 1360 m.s.m.

9.16. Rhynchospora setigera Griseb., Fl. Brit. W. I., p. 577.1864.

Fig. $7 \mathrm{f}-\mathrm{h}$

Plantas $30-60 \mathrm{~cm}$ alt., perenes, rizomas curtos. Folhas basilares, bainhas desfeitas em fibras, na maturação; lâminas foliares planas, flácidas, (5-)8-18 cm × 1,8-2 mm, glabras. Colmos triangulares. Brácteas involucrais $3-4$, foliáceas, totalmente verdes, a mais inferior 3-6,5 cm compr., mais longa do que a inflorescência. Inflorescência terninal monocéfala, globosa, 7-9 $\mathrm{mm}$ compr. Espiguetas 30-50 espiguetas, sésseis, 2,5-3 × 1-1,5 $\mathrm{mm}$, brancas; glumas elípticas, ápice obtuso, reto.
Cerdas perigoniais ausentes. Estames 3. Estigmas 2 -fidos. Aquênios 2 ou mais por espigueta, 1-1,5× $1,2 \mathrm{~mm}$, subglobosos, superfície transversalmente rugosa, palhetes a brancos, estilopódio ca. $0,5 \mathrm{~mm}$ compr., triangular, base decurrente sobre o fruto $\mathrm{e}$ totalmente aderida a ele.

Material examinado: $20^{\circ} 30^{\prime} 22^{\prime \prime} \mathrm{S} 43^{\circ} 37^{\prime} 59,3^{\prime \prime} \mathrm{W}$, 2.XII.2007, s.fl., s.fr., H.M. Longhi-Wagner et al. 10342 (ICN); 20²9'14,5”'S 4341'13,9”W, 3.XII.2007, s.fl., s.fr., H.M. Longhi-Wagner et al. 10403 (ICN, K, VIC). Material adicional: RIO GRANDE DO SUL: Porto Alegre, Morro Santana, 27.IX.2004, fl., fr., A.C. Araújo \& G. Silveira $1596(\mathrm{ICN})$.

Rhynchospora setigera é referida para as regiões tropicais e subtropicais da América do Sul (Thomas 1998), sendo citada para todas as regiões do Brasil, exceto Amazônia (Alves et al. 2013). $\mathrm{Na}$ SOB foi encontrada em campos graminosos quartzíticos de encosta úmida, entre 1270 e 1450 m.s.m. Espécie facilmente reconhecida pela inflorescência monocéfala, globosa e espiguetas com glumas totalmente brancas.

\subsection{Rhynchospora tenella (Nees) Boeck.,} Linnaea 37:595. 1873.

Fig. 7i-k

Plantas $20-30 \mathrm{~cm}$ alt., perenes, rizomas curtos. Folhas basilares e também distribuídas ao longo do colmo, bainhas íntegras na maturação; lâminas foliares conduplicadas ou filiformes, flácidas, ca. $10-15 \mathrm{~cm} \times 0,6 \mathrm{~mm}$, glabras. Colmos cilíndricos, sulcados. Bráctea involucral 1, foliácea, totalmente verde, 10-16 cm compr., mais longa do que a inflorescência. Inflorescência terminal e lateral, (1,5-)2-3,5 cm compr., antelódio em fascículos laxos. Espiguetas 1-2 no ápice dos ramos, pediceladas, 3-4,5 × 0,7-1 mm, palhetes; glumas lanceoladas, ápice agudo, reto. Cerdas perigoniais ausentes. Estames 1. Estigmas 2-fidos. Aquênio um por espigueta, ca. 1-1,2 $\times 0,8 \mathrm{~mm}$, obovóide, superfície transversalmente rugosa, palhete a castanho, estilopódio $0,2-0,4 \mathrm{~mm}$ compr., triangular, subagudo, base não decurrente sobre o fruto e totalmente aderida a ele.

Material examinado: $20^{\circ} 30^{\prime} 21^{\prime \prime} \mathrm{S} 43^{\circ} 38^{\prime} 16^{\prime \prime} \mathrm{W}$, 15.III.2005, fl. e fr., H.M. Longhi-Wagner et al. 9549 (ICN, VIC).

Rhynchospora tenella tem distribuição nas regiões tropicais e subtropicais da América do Sul (Thomas 1998). No Brasil, está presente em quase todas as regiões, em campos úmidos e cerrado (Thomas 1998; Rocha \& Luceño 2002). Na SOB é rara, sendo encontrada em campos graminosos quartzíticos entre afloramentos rochosos, em solos arenosos, a ca. 1560 m.s.m. 
9.18. Rhynchospora tenuis Willd. ex Link, Jahrb. Gewächsk. 1(3): 76. 1820.

Fig. 71

Plantas $10-15 \mathrm{~cm}$ alt., perenes, rizomas curtos. Folhas basilares e também distribuídas ao longo do colmo, bainhas íntegras na maturação; lâminas foliares convolutas a cilíndricas, flácidas, $10-13 \mathrm{~cm} \times 2-3 \mathrm{~mm}$, glabras. Colmos triangulares. Brácteas involucrais 1(-2), foliáceas, totalmente verdes, a mais inferior $2,5-4,5 \mathrm{~cm}$ compr., mais longa do que a inflorescência. Inflorescência terminal, 2-2,5 cm compr., antelódio em fascículos laxos. Espiguetas 3-5, pediceladas, ca. 3,5 × 0,7-1 $\mathrm{mm}$, castanhas; glumas oval-lanceoladas, ápice apiculado, reto. Cerdas perigoniais ausentes. Estames 3. Estigmas 2-fidos. Aquênio 1-2 por espigueta, ca. $0,8 \times 0,7 \mathrm{~mm}$, obovóide, superfície transversalmente rugosa, palhete a castanhoalaranjado; estilopódio ca. 0,2 mm compr., deltóide, base não decurrente sobre o fruto, e totalmente aderida a ele.

Material examinado: s.d., fl., R.J. Alves \& J. Becker 1523 (ICN, R); 20²8’41,3”'S 4344’3”W, 4.XII.2007, fl., H.M. Longhi-Wagner et al. 10463 (ICN, K, VIC).

Material adicional: MINAS GERAIS: Diamantina, $18^{\circ} 14^{\prime}$ 'S, 4336'W, 16.II.1991, fr., M.M. Arbo et al. $5196(\mathrm{~K})$.

Rhynchospora tenuis está presente em regiões tropicais e subtropicais, desde o México até a Argentina (Rocha \& Luceño 2002). No Brasil ocorre em quase todas as regiões, em campos úmidos e em cerrado (Rocha \& Luceño 2002). $\mathrm{Na}$ SOB foi encontrada em solos arenosos, entre afloramentos rochosos, entre 1420 e 1500 m.s.m.

9.19. Rhynchospora velutina (Kunth) Boeck., Vidensk. Meddel. Dansk Naturhist. Foren. Kjobenhavn 1869: 149. $1869 . \quad$ Fig. 7m-p

Plantas $70-90 \mathrm{~cm}$ alt., perenes, rizomas curtos. Folhas basilares, bainhas íntegras na maturação; lâminas foliares planas a conduplicadas, flácidas, ca. $30-40 \mathrm{~cm} \times 3 \mathrm{~mm}$, velutinas. Colmos subcilíndricos. Brácteas involucrais 1(3), foliáceas, a mais inferior 4-6 cm compr., mais curta do que a inflorescência. Inflorescência terminal e lateral, (5-)8-15(-20) cm compr., antelódio em fascículos laxos. Espiguetas 2-6, pediceladas, 7-8 $\times 1-1,5 \mathrm{~mm}$, castanhas, margens brancas; glumas elíptico-lanceoladas, ápice agudo a mucronado, reto. Cerdas perigoniais ausentes. Estames 3. Estigmas curtamente 2-fidos. Aquênio 2 ou mais por espigueta, ca. 1,8 × 1,5 mm, suborbicular, superfície transversalmente rugosa, esbranquiçado a palhete claro, estilopódio ca. 0,7 mm compr., triangular, base bilobada, decurrente sobre o fruto e totalmente aderida a ele.

Material examinado: $20^{\circ} 28^{\prime} 51,4^{\prime \prime} \mathrm{S} 43^{\circ} 43^{\prime} 11,4$ ' W, 9.I.2006, fl., H.M. Longhi-Wagner \& C.C. de Paula 10033 (ICN, VIC).

Material adicional: GOIÁS: Alto Paraíso de Goiás, Chapada dos Veadeiros, Parque Nacional, 14.V.1986, fl. e fr., S. Romaniuc et al. 458 (ICN).

Rhynchospora velutina está referida para as regiões tropicais e subtropicais das Américas Central e do Sul (Thomas 1994, 1998). No Brasil é referida para a área tropical nos Domínios fitogeográficos da Amazônia, Cerrado e Mata Atlântica (Alves et al. 2013). Na Serra do Ouro Branco é comum e foi encontrada em campos brejosos, a 1450 m.s.m. O espécime H.M. LonghiWagner et al. 10427 (ICN, VIC) se assemelha a Rhynchospora velutina, porém, as lâminas foliares apresentam tricomas muito curtos e esparsos nas margens e na face dorsal, diferentemente do que é caraterístico desta espécie. Este exemplar poderia representar uma variação de $R$. velutina, porém a confirmação da espécie só pode ser feita através da análise do fruto, o qual não está presente no espécime analisado.

9.20. Rhynchospora warmingii Boeck., Vidensk. Meddel. Naturhist. Foren. Kjøbenhavn 1869: 143. 1869.

Fig. $7 \mathrm{q}-\mathrm{r}$

Plantas $28-40 \mathrm{~cm}$ alt., perenes, rizomas longos. Folhas basilares, bainhas desfeitas em fibras, na maturação; lâminas foliares cilíndricas, flácidas, $10-20 \mathrm{~cm} \times 1(-1,1) \mathrm{mm}$, glabras ou glabrescentes. Colmos cilíndricos. Brácteas involucrais 2(3), foliáceas, brancas na base, em ambas as faces, e verdes no ápice, a mais inferior 2-5,5 cm compr., mais longa do que a inflorescência. Inflorescência terminal monocéfala, hemisférica, $0,5-0,8 \times 0,8-1$ $\mathrm{cm}$. Espiguetas 5-15, sésseis, ca. $4 \times 2-2,5 \mathrm{~mm}$, palhetes; glumas elíptico-lanceoladas, atenuadas a mucronadas, ápice reto. Cerdas perigoniais $2(-3)$, escabras, 0,5-1 mm compr. Estames 2. Estigmas indivisos. Aquênio 1 por espigueta, 1,7-2 $\times$ 1,5-1,8 mm, obovóide, superfície transversalmente tuberculada, castanho a amarronzado, estilopódio 0,5-0,6 mm compr., cônico, base não decurrente sobre o fruto e totalmente aderida a ele.

Material examinado: 2.X.1988, fr., F.R.C. da Silva (BHCB 14016); 20³0'22”'S 4337'59,3”W, 2.XII.2007, fl. e fr., H.M. Longhi-Wagner et al. 10344 (ICN, K); $20^{\circ} 29^{\prime} 7,2^{\prime \prime} \mathrm{S} 43^{\circ} 43^{\prime} 22,7$ 'W, 4.XII.2007, fl., H.M. Longhi-Wagner et al. 10450 (ICN, VIC); 20³0'29,9'S 43³7'47,3”W, 5.XII.2007, fl., H.M. Longhi-Wagner et al. 10489 (ICN, VIC). 
Rhynchospora warmingii é registrada para a Bolívia e Brasil, neste último em áreas de campo rupestre da Cadeia do Espinhaço, nos estados da Bahia e Minas Gerais, e também no Estado de São Paulo (Araújo et al. 2012). Na SOB é comum e foi encontrada em campos graminosos quartzíticos, entre 1150 e 1280 m.s.m. Esta espécie foi referida como ameaçada em MMA (2013) visto que não vinha sendo observada no campo desde a década de 1950, exceto por uma única coleta registrada para a Bahia em 2000 (Araújo et al. 2012). Os registros obtidos na SOB ampliam a área de distribuição conhecida da espécie de forma que a mesma deve ser considerada LC ("least concern") de acordo com as normas da IUCN (2013).

\section{Scleria Berg.}

Plantas perenes ou anuais, com ou sem rizomas. Folhas basilares ou distribuídas ao longo do colmo, com bainhas e lâminas desenvolvidas, lígula raramente presente, contralígula geralmente presente, às vezes acompanhada de um apêndice membranoso; bainhas aladas ou não aladas, o ápice glabro, lâminas planas ou filiformes. Colmos triangulares. Brácteas involucrais presentes ou ausentes. Inflorescência do tipo antelódio, simples ou composto, ou paniculódio, ou inflorescência monocéfala ou, ainda, espiguetas dispostas em fascículos ao longo da ráquis. Espiguetas pistiladas unifloras, sésseis, basais, as estaminadas plurifloras, pediceladas (sésseis em $S$. distans Poir.), apicais em cada ramo, cilíndricas, glumas de disposição espiralada sobre a ráquila. Flores pistiladas com perigônio representado pelo hipogínio cupuliforme persistente na base do fruto, ou perigônio ausente, as estaminadas sem perigônio; estames 1-3; estigmas 3-fidos, base do estilete não dilatada e não persistente sobre o fruto, estilopódio ausente. Aquênio globoso, com seção transversal circular, não alado, não envolto por um utrículo, superfície lisa, verrucosa, tuberculada, papilosa ou transversalmente rugosa (Camelbeke et al. 2003).

Scleria compreende 200-250 espécies (Core 1936; Goetghebeur 1998; Camelbeke et al. 2003) distribuídas em áreas tropicais e subtropicais, com maior diversidade na região neotropical (Guaglianone 2001). Está representado na SOB por três espécies.

\section{Chave para espécies de Scleria da Serra do Ouro Branco}

1. Plantas 60-70 cm alt., umbrófilas. Bainhas foliares aladas. Lâminas foliares 20-28 mm larg. Hipogínio presente, fimbriado 10.2. Scleria latifolia

1'. Plantas 20-40 cm alt., heliófilas. Bainhas foliares não aladas. Lâminas foliares 1-3,5 mm larg. Hipogínio ausente.

2. Paniculódio espiciforme, não ramificado; espiguetas todas sésseis. Aquênio liso

10.1. Scleria distans

2'. Paniculódio laxo, ramificado; espiguetas sésseis e pediceladas na mesma inflorescência. Aquênio verrucoso 10.3. Scleria leptostachya

10.1. Scleria distans Poir. in Lam., Encycl. 7: 4. 1806. Fig. $8 \mathrm{a}$

Plantas $25-35 \mathrm{~cm}$ alt., perenes, rizomas bem desenvolvidos. Folhas dispostas ao longo do colmo, lígula ausente, contralígula com o ápice agudo, glabro, sem apêndice membranoso; bainhas foliares não aladas; lâminas $10-15 \mathrm{~cm} \times 3-3,5 \mathrm{~mm}$, planas, pilosas. Brácteas involucrais ausentes. Paniculódio espiciforme, não ramificado, 6-8 $\mathrm{cm}$ compr. Espiguetas unissexuadas, todas sésseis, as pistiladas ca. 4-5 $\times 2,5 \mathrm{~mm}$, perigônio ausente; as estaminadas ca. $4 \times 1,5 \mathrm{~mm}$; estames 2 . Aquênio ca. $1,5 \times 1 \mathrm{~mm}$, hipogínio ausente, superfície lisa, branco.

Material examinado: $20^{\circ} 29^{\prime} 6,3^{\prime \prime} \mathrm{S} 43^{\circ} 42^{\prime} 40,8^{\prime \prime} \mathrm{W}$, 8.I.2006, fl. e fr., H.M. Longhi-Wagner \& C.C. de Paula 9948 (ICN, VIC).
Scleria distans é pantropical, presente também em zonas subropicais (Camelbeke et al. 2003). Ocorre em todas as regiões do Brasil, em ambientes abertos de solos úmidos a encharcados, ricos em matéria orgânica (Araújo 2009b). Na SOB é comum e foi encontrada em campos graminosos quartzíticos úmidos, a 1580 m.s.m. Espécie reconhecida no campo pela inflorescência espiciforme e aquênio branco com a superfície lisa.

10.2. Scleria latifolia Sw., Prodr., v. 18. 1788.

Fig. $8 b-e$

Plantas $60-70 \mathrm{~cm}$ alt., perenes, rizomas desenvolvidos. Folhas dispostas ao longo do colmo, lígula ausente, contralígula com o ápice subagudo, glabro, sem apêndice membranoso; 
bainhas foliares aladas; lâminas $15-25 \mathrm{~cm} \times$ 20-28 mm, planas, glabras. Brácteas involucrais ausentes. Paniculódio ramificado, 7-8 cm compr. Espiguetas unissexuadas, as pistiladas 4-5 × 2-2,5 $\mathrm{mm}$, sesseis, perigônio ausente; as estaminadas ca. $4 \times 1 \mathrm{~mm}$, pediceladas; estames 2 . Aquênio ca. 4 $\times 4 \mathrm{~mm}$, hipogínio presente, fimbriado, superfície lisa, violáceo a negro-violáceo.

Material examinado: $20^{\circ} 29^{\prime} 22,9^{\prime \prime} \mathrm{S} 43^{\circ} 41^{\prime} 13,8^{\prime \prime} \mathrm{W}$, 3.XII.2007, fl. e fr., H.M. Longhi-Wagner et al. 10417 (ICN).

Scleria latifolia apresenta distribuição ampla em toda a Região Neotropical, em borda ou interior de mata úmida, às vezes em matas alteradas (Camelbeke et al. 2003). Amplamente distribuída no Brasil, nas vegetações do domínio da Mata Atlântica (Muniz \& Shepherd 1987). Na SOB é pouco comum, sendo encontrada no interior e beira de mata de galeria, a 1350 m.s.m. Espécie facilmente reconhecida pelas bainhas foliares aladas, lâminas foliares bem largas e aquênio violáceo a negro-violáceo.

10.3. Scleria leptostachya Kunth, Enum. Pl. 2: 354. 1837.

Fig. $8 \mathrm{f}-\mathrm{g}$

Plantas $20-40 \mathrm{~cm}$ alt., perenes, rizomas curtos. Folhas dispostas ao longo do colmo, lígula ausente, contralígula com o ápice truncado, glabrescente, sem apêndice membranoso; bainhas foliares não aladas; lâminas $12-20 \mathrm{~cm} \times 1-1,5$ $\mathrm{mm}$, planas, glabras. Brácteas involucrais ausentes. Paniculódio ramificado, 5-8 cm compr. Espiguetas unissexuadas, sésseis ou pediceladas, as pistiladas 3-4 × 2-2,5 mm, perigônio ausente; as estaminadas ca. $4 \times 1 \mathrm{~mm}$; estames 2 . Aquênio ca. $1,2 \times 1 \mathrm{~mm}$, hipogínio ausente, superfície verrucosa, branco. Material examinado: $20^{\circ} 29^{\prime} 4,2^{\prime \prime} \mathrm{S} 43^{\circ} 42^{\prime} 22,7^{\prime}{ }^{\prime} \mathrm{W}$, 20.III.2004, fl. e fr., R.A.X. Borges 53 (OUPR).

Scleria leptostachya ocorre na América do Sul, desde a Venezuela até a Argentina (WCSP 2013). No Brasil, está referida para todas as regiões (Araújo 2009b). Na SOB é pouco comum e foi encontrada em campo rupestre limpo, a 1480 m.s.m. Espécie de porte delicado, semelhante à $S$. distans, porém com inflorescência ramificada e aquênio de superfície verrucosa.

\section{Trilepis Nees}

Plantas perenes, rizomas curtos. Folhas basilares, menos comumente distribuídas ao longo do colmo, com bainhas e lâminas desenvolvidas, lígula ausente, contralígula presente; bainhas com o ápice glabro ou piloso, não hialino e não marcescente; lâminas planas ou conduplicadas, alterno-espiraladas ou em roseta. Colmos triangulares ou cilíndricos. Brácteas involucrais presentes. Inflorescências com as espiguetas agrupadas em fascículos dispostos ao longo da ráquis, cada fascículo com espiguetas estaminadas e pistiladas. Espiguetas unissexuadas, unifloras ou bifloras, as estaminadas basais e as pistiladas apicais em cada fascículo, ambas comprimidas lateralmente, glumas de disposição dística sobre a ráquila. Flores unissexuadas, as estaminadas sem perigônio, estames 3 , as pistiladas com perigônio escamiforme, escamas muito curtas e longamente fimbriadas, persistentes na base do fruto, estigmas 3 -fidos; aquênio oblongo, estilopódio ausente, base do estilete não dilatada e não persistente sobre o fruto, não alado, superfície levemente rugosa, envolto por um utrículo oblongoacuminado (Vitta 2002).

Trilepis compreende cinco espécies, no Escudo das Guianas e nas montanhas do sudeste do Brasil até o Estado da Bahia (Vitta 2002). Está representado na SOB por uma espécie.

11.1. Trilepis Ihotzkiana Nees, Edinburgh New Philos. J. 17: 267. 1834.

Fig. 8h-k

Plantas 5-12 cm alt., anuais, rizomas ausentes. Folhas dispostas em roseta; lâminas conduplicadas, $2-3 \mathrm{~cm} \times 1 \mathrm{~mm}$. Colmos triangulares. Bráctea involucral 1, 7-8 mm compr., mais curta do que a inflorescência. Espigas 5-8 reunidas em fascículos congestos no ápice dos ramos. Espiguetas estaminadas 2-3, 2,5-4 × 0,5-0,7 mm, vináceas. Estames 3. Espiguetas pistiladas 3-5, apicais, 3-4 $\times 0,5 \mathrm{~mm}$, vináceas. Estigmas 3 -fidos. Escamas perigoniais muito curtas, longamente fimbriadas, persistentes na base do utrículo. Utrículo 2,5-3,5 × $0,5 \mathrm{~mm}$, subtriangular, oblongo-acuminado, palhete a ligeiramente esverdeado.

Material examinado: $20^{\circ} 30^{\prime} 22^{\prime \prime} \mathrm{S} 43^{\circ} 37^{\prime} 59,3$ ”'W, 2.XII.2007, fr., H.M. Longhi-Wagner et al. 10352 (ICN, K, VIC); $20^{\circ} 28^{\prime} 29,5^{\prime \prime} \mathrm{S} 43^{\circ} 43^{\prime} 55,1^{\prime \prime} \mathrm{W}, 4 . X I I .2007$, fl. e fr., H.M. Longhi-Wagner et al. 10466 (ICN, VIC).

Trilepis lhotzkiana é nativa da América do Sul Setentrional, referida para a Venezuela e Brasil (WCSP 2013). No Brasil ocorre nos estados da Região Sudeste e na Bahia (Vitta 2002). Espécie rupícola, comum em rochas quartzíticas ou areníticas, ao longo da Cadeia do Espinhaço. $\mathrm{Na}$ SOB foi encontrada em solos arenosos em formação, com musgos, em frestas e entre rochas quartzíticas, entre 1280 e 1320 m.s.m. 

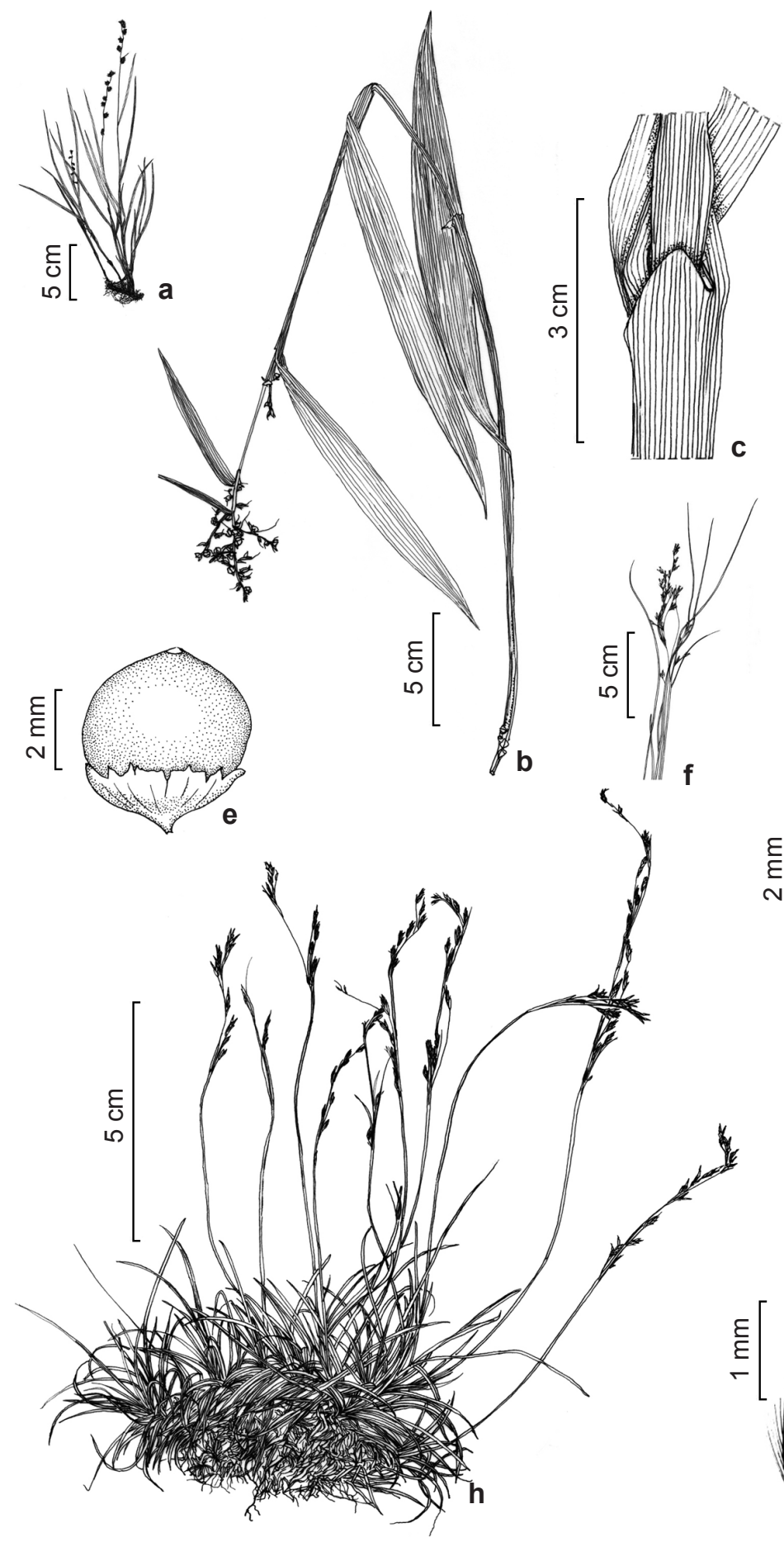

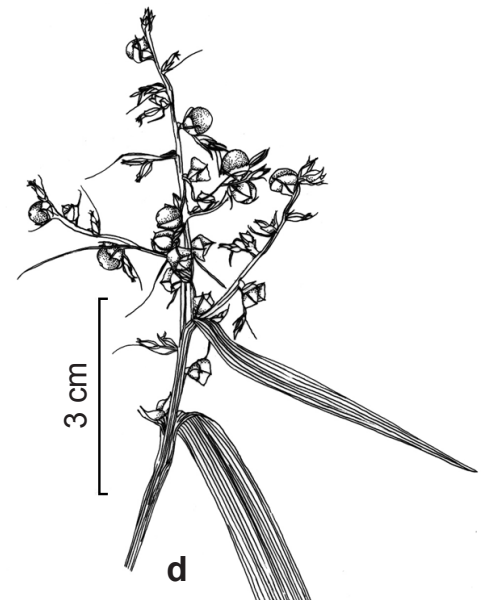

(1)
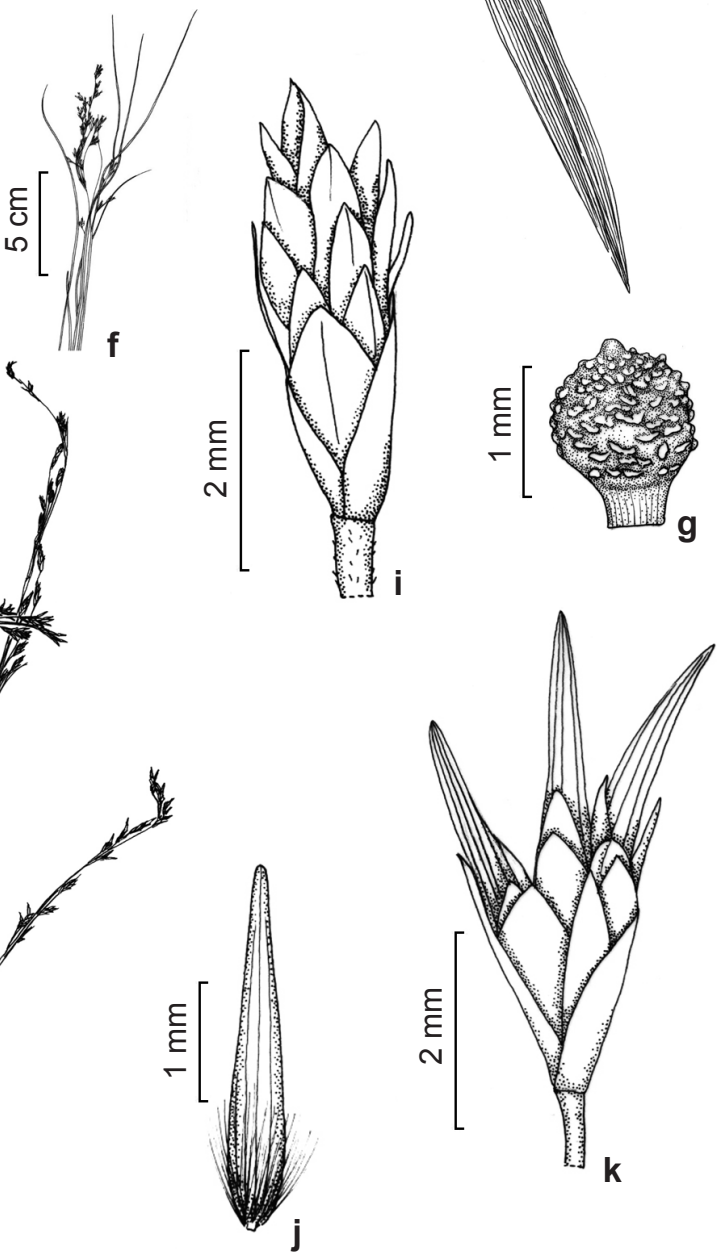

Figura 8 - a. Scleria distans - hábito. b-e. S. latifólia - b. colmo com inflorescência; c. ápice da bainha foliar e contralígula subaguda; d. inflorescência; e. aquênio com hipogínio. f-g. S. leptostachya -f. inflorescência; g. aquênio. h-k. Trilepis lhotzkiana -h. hábito; i. espigueta estaminada; j. espigueta pistilada; k. utrículo com escamas perigoniais na base (a H.M. Longhi-Wagner \& C.C. de Paula 9948; b-e H.M. Longhi-Wagner et al. 10417; f-g R.A.X. Borges 53; h-k H.M. Longhi-Wagner et al. 10352). Figure 8 - a. Scleria distans - habit. b-e. S. latifolia - b. culm and inflorescence; c. apex of leaf sheath, contraligule subacute; d. inflorescence; e. achene and hypogyneo. f-g. S. leptostachya - f. inflorescence; g. achene. h-k. Trilepis lhotzkiana - h. habit; i. male spikelet; j. female spikelet; k. utriculum with perigonium scales at the base (a H.M. Longhi-Wagner \& C.C. de Paula 9948; b-e H.M. Longhi-Wagner et al. 10417; f-g R.A.X. Borges 53; h-k H.M. Longhi-Wagner et al. 10352). 


\section{Agradecimentos}

As autoras agradecem ao Professor Cláudio Coelho de Paula (Universidade Federal de Viçosa) coordenador do projeto "Flora da Serra do Ouro Branco", o convite para estudar Cyperaceae e o apoio e participação nos trabalhos de campo. À Gerdau/Açominas, através do Projeto Germinar, o apoio financeiro e logístico. Ao Conselho Nacional de Desenvolvimento Científico e Tecnológico - CNPq, a Bolsa de Produtividade em Pesquisa concedida à primeira autora, a Bolsa de Incentivo à Taxonomia concedida à segunda autora, e o apoio financeiro. À Synthesys (European Union-funded Integrated Activities Grant), o apoio financeiro concedido à segunda autora para visita ao Herbário de Berlim.

\section{Referências}

Acevedo-Rodrigues, P. \& Strong, M.T. 2005. Monocotyledons and Gymnosperms of Puerto Rico and the Virgin Islands. Contributions from the United States National Herbarium 52: 1-415.

Adams, C.D. 1994a. Bulbostylis Kunth. In: Davidse, G.; Sousa S.M. \& Chater, A.O. (eds.). Flora mesoamericana. Vol. 6. Universidad Nacional Autónoma de Mexico, Ciudad de Mexico. Pp. 452-455.

Adams, C.D. 1994b. Fimbristylis Vahl. In: Davidse, G.; Sousa S.M. \& Chater, A.O. (eds.). Flora. mesoamericana. Vol. 6. Universidad Nacional Autónoma de Mexico, Ciudad de Mexico. Pp. 455-457.

Adams, C.D. \& Goetghebeur, P. 1994. Lipocarpha R. Br. In: Davidse, G.; Sousa S.M. \& Chater, A.O. (eds.). Flora mesoamericana. Vol. 6. Universidad Nacional Autónoma de Mexico, Ciudad de Mexico. Pp. 446-447.

Alves, M.; Araújo, A.C.; Prata, A.P.; Vitta, F.; Hefler, S.; Trevisan, R.; Gil, A.S.B.; Martins, S. \& Thomas, W.W. 2013. Cyperaceae. In: Lista de espécies da flora do Brasil. Jardim Botânico do Rio de Janeiro. Disponível em $<$ http://floradobrasil.jbrj. gov.br/2013/FB000171>. Acesso em 30 Jul 2013.

Araújo, A.C. 2009a. Rhynchospora Vahl, In: Cavalcanti, T.B. \& Batista, M.F. (eds.). Flora do Distrito Federal, Brasil. Vol. 7. Embrapa, Brasília. Pp. 125-153.

Araújo, A.C. 2009b. Scleria P.J. Bergius. In: Cavalcanti, T.B. \& Batista, M.F. (eds.). Flora do Distrito Federal, Brasil. Vol. 7. Embrapa, Brasília. Pp. 153-164.

Araújo, A.C.; César, E. \& Simpson, D.A. 2007. Lista preliminar da família Cyperaceae na Região Nordeste do Brasil. Série Repatriamento de Dados do Herbário Kew para a Flora do Nordeste do Brasil 3. Royal Botanic Gardens, Kew Press, Londres. 32p.
Araújo, A.C. \& Longhi-Wagner, H.M. 1996. Levantamento taxonômico de Cyperus L. subg. Anosporum (Nees) Clarke (Cyperaceae-Cypereae) no Rio Grande do Sul, Brasil. Acta Botanica Brasilica 10: 153-192.

Araújo, A.C.; Longhi-Wagner, H.M. \& Thomas, W.W. 2012. A synopsis of Rhynchospora sect. Pluriflorae (Cyperaceae). Brittonia 64: 381-393.

Barros, M. 1960. Las Ciperáceas del estado de Santa Catalina. Sellowia 12: 181-450.

Beentje, H. 2010. The Kew plant glossary. An illustrated dictionary of plants terms. Kew Publishing, Richmond. 160p.

Borges, R.A.X.; Carneiro, M.A.A. \& Viana, P.L. 2011. Altitudinal distribution and species richness of herbaceous plants in campos rupestres of the Southern Espinhaço Range, Minas Gerais, Brazil. Rodriguésia 62: 139-152.

Camelbeke, K.; Spruyt, K. \& Goetghebeur, P. 2003. The genus Scleria (Cyperaceae) in Bolívia. Revista de la Sociedad Boliviana de Botánica 4: 139-170.

Clarke, C.B. 1908. New genera and species of Cyperaceae. Kew Bulletin Addittional Series 8: 1-196.

Core, E.L. 1936. The American species of Scleria. Brittonia 2: 1-108.

Fundação Biodiversitas. 2001. Revisão das Listas Vermelhas da Flora e da Fauna Ameaçadas de Extinção de Minas Gerais. Relatório. Vols. 1 e 2.

Giulietti, A.M.; Rapini, A.; Andrade, M.J.G.; Queiroz, L.P. \& Silva, J.M.C. (orgs.). 2009. Plantas raras do Brasil. Vol. 1. Conservação Internacional, Belo Horizonte. 496p.

Goetghebeur, P. 1998. Cyperaceae,: In: Kubitzki, K. (ed.) The families and genera of vascular plants. Vol. 4. Koeltz Scientific Books, Koenigstein. Pp. 141-190.

Govaerts, R.; Simpson, D.A.; Bruhl, J.; Egorova, T.; Goetghebeur, P. \& Wilson, K. 2007. World Checklist of Cyperaceae - Sedges. Kew Publishing, London. 780p.

González, E.M.S. 1994. Eleocharis R. Br. In: Davidse, G.; Sousa S.M. \& Chater, A.O. (eds.). Flora mesoamericana. Vol. 6. Universidad Nacional Autónoma de Mexico, Ciudad de Mexico. Pp. 458-464.

Guaglianone, E.R. 1979. Sobre Rhynchospora rugosa (Vahl) Gale (Cyperaceae) y algunas especies afines. Darwiniana 22: 255-311.

Guaglianone, E.R. 2001. Contribución al estudio del género Rhynchospora (Cyperaceae). V. sección Longirostres en América Austral. Darwiniana 39: 286-342.

Harley, R.M. \& Simmons, N.A. 1986. Flórula of Mucugê - Chapada Diamantina, Bahia, Brazil, Royal Botanic Gardens, Kew, London. 228p. 
Hefler, S.M. \& Longhi-Wagner, H.M. 2012. Cyperus L. subgen. Cyperus (Cyperaceae) na Região Sul do Brasil. Revista Brasileira de Biociências 10: 327-372.

Heywood, V.W.; Brummitt, R.K.; Culham, A. \& Seberg, O. 2007. Flowering Plant families of the World Cyperaceae. Kew Press, Richmond. Pp. 363-365.

IUCN. [continuously update]. 2013. The IUCN Red List of Threatened Species. Disponível em $<\mathrm{http}$ : $\backslash w w w$. iucnredlist.org/>. Acesso em 22 Jul 2013.

"JSTOR Online". [continuously update]. 2013. Jstor Plant Science. Disponível em $<$ http://plants.jstor. org >. Acesso em 7 Jul 2013.

Kearns, D.M. 1998. Lagenocarpus Nees. In: Steyermark, J.A.; Berry, P.E. \& Holst, B.K. (eds.). Flora of the Venezuelan Guayana - Caesalpiniaceae-Ericaceae. Vol. 4. MBG Press, St. Louis. Pp. 590-594.

Kral, R. 1971. A treatment of Abildgaardia, Bulbostylis and Fimbristylis (Cyperaceae) for North America. Sida 4: 57-227.

Kral, R. 1998. Bulbostylis Kunth. In: Steyermark, J.A.; Berry, P.E. \& Holst, B.K. (eds.). Flora of the Venezuelan Guayana - Caesalpiniaceae-Ericaceae. Vol. 4. MBG Press, St. Louis. Pp. 505-514.

López, M.G. 2007. Tres nuevas especies en el género Bulbostylis (Cyperaceae) de Sudamérica. Novon 17: 497-502.

Magalhães, G.M. 1966. Sobre os cerrados de Minas Gerais. Anais da Academia Brasileira de Ciências 38 (suppl.): 59-69.

Mayo, S. 1987. Cyperaceae. In: Giulietti, A.M.; Menezes, N.L.; Pirani, J.R.; Meguro, M. \& Wanderly, M.G.L. (orgs.), Flora da Serra do Cipó, Minas Gerais: caracterização e lista das espécies. Boletim de Botânica da Universidade de São Paulo 9: 109- 111.

Meguro, M.; Pirani, J.R.; Giulietti, A.M. \& Mello-Silva, R. 1994. Phytophysiognomy and composition of the vegetation of Serra do Ambrósio, Minas Gerais, Brazil. Revista Brasileira de Botânica 17: 149-166.

MMA. 2013. Lista Oficial das Espécies da Flora Brasileira Ameaçadas de Extinção. Disponível em < http://www.mma.gov.br>. Acesso em 24 Jul 2013.

MOBOT 2013. Trópicos. Missouri Botanical Garden Database. Disponível em <http://www.tropicos. org/>. Acesso em 13 Ago 2013.

Muniz, C. \& G.J. Shepherd. 1987. O gênero Scleria Berg. (Cyperaceae) no estado de São Paulo. Revista Brasileira de Botânica 10: 63-94.

Nees von Esenbeck, C.G.D. 1834. Synopsis Generum Cyperacearum. Linnaea 9: 282-306.

Nees von Esenbeck, C.G.D. 1842. Cyperaceae. In: Martius, C.F.P. von; Eichler, A.W. \& Urban, I. Flora brasiliensis. Munchen, Wien, Leipzig. Vol. 2, part 1. Pp. 110-147.
Paula C.C.; Silva, R.R. \& Oliveira, D.A.S. 2005. A Serra do Ouro Branco. Universidade Federal de Viçosa, Viçosa. 50p.

Prata, A. 2004. Bulbostylis Kunth (Cyperaceae) no Brasil. Tese de Doutorado. Universidade de São Paulo, São Paulo. 197p.

Rocha, E.A. \& Luceño, M. 2002. Estudo taxonômico de Rhynchospora Vahl section Tenues (Cyperaceae) no Brasil. Hoehnea 29: 189-214.

Santos, M.F. \& Sano, P.T. 2012. Flora fanerogâmica da Serra do Ouro Branco, Minas Gerais: Myrtaceae. Rodriguésia 63: 1065-1083.

Simpson, D.A. 1995. Cyperaceae. In: Stannard, B.L. (ed.). Flora of Pico das Almas - Chapada Diamantina, Bahia - Brasil. Royal Botanic Gardens, Kew. Pp. 661682.

Strong, M.T. 1997. Machaerina (Cyperaceae) in South America. Novon 7: 308-319.

Strong, M.T. 2006. Taxonomy and distribution of Rhynchospora (Cyperaceae) in the Guianas, South America. Contributions from the United States National Herbarium 53: 1-225.

Thiers, B. [continuously updated]. Index Herbariorum: A global directory of public herbaria and associated staff. New York Botanical Garden's Virtual Herbarium. Disponível em <http://sweetgum.nybg. org/ih/>. Acesso em 4 Abr 2013.

Thomas, W.W. 1994. Rhynchospora Vahl. In: Davidse, G.; Sousa S.M. \& Chater, A.O. (eds.). Flora mesoamericana. Vol. 6. Universidad Nacional Autónoma de Mexico, Ciudad de Mexico. Pp. 404-422.

Thomas, W.W. 1998. Rhynchospora Vahl. In: Steyermark, J.A.; Berry, P.E. \& Holst, B.K. (eds.). Flora of the Venezuelan Guayana - Caesalpiniaceae-Ericaceae. Vol. 4. MBG Press, St. Louis. Pp. 610-639.

Thomas, W.W. 2004. Cyperaceae Juss. In: Smith, N.; Mori, S.A.; Henderson, A.; Stevenson, D.W. \& Heald, S.V. (eds.) Flowering plants of the Neotropics. NYBG Press, New York. Pp. 434-436.

Trevisan, R. \& Boldrini, I.I. 2008. O gênero Eleocharis R. Br. (Cyperaceae) no Rio Grande do Sul, Brasil. Revista Brasileira de Biociências 6: 7-67.

Viana, P.L. \& Lombardi, J.A. 2007. Florística e caracterização dos campos rupestres sobre canga na Serra da Calçada, Minas Gerais, Brasil. Rodriguésia 58: 159-177.

Vitta, F.A. 2002. Trilepis tenuis (Cyperaceae Trilepideae), a new species from Rio de Janeiro, southeastern Brazil. Brittonia 54: 120-123.

Vitta, F.A. 2005. Revisão taxonômica e estudos morfológicos e biossistemáticos em Cryptangium Schrad. ex Nees e Lagenocarpus Nees (Cyperaceae: Cryptangieae). Tese de Doutorado, Universidade de Campinas, Campinas. 294p. 
Vitta, F.A. \& Prata, A.P. 2009. Flora de Grão-Mogol, Minas Gerais: Cyperaceae. Boletim do Instituto de Botânica 27: 43-62.

WCSP (2013). [continuously updated]. World Checklist of Cyperaceae. Disponível em <http://Apps.Kew. Org/Wcsp/>. Acesso em 7 Nov 2012.
Zappi, D.C.; Lucas, E.; Stannard, B.L.; Nic Lughadha, E.; Pirani, J.R.; Queiroz, L.P.; Atkins, S.; Hind, D.J.N.; Giulietti, A.M.; Harley, R.M. \& Carvalho, A.M. 2003. Lista das plantas vasculares de Catolés, Chapada Diamantina, Bahia, Brasil. Boletim de Botânica da Universidade de São Paulo 21: 345-398.

\footnotetext{
Anexo

Glossário

Antelódio - inflorescência ramificada, com ramos floríferos de uma ou várias ordens, sendo o ramo central mais curto do que os laterais. Pode ser simples (só ramos de primeira ordem) ou composto (ramos de várias ordens). Este tipo de inflorescência é denominado de umbela ou antela, por alguns autores.

Bráctea da espigueta - bráctea estéril uniquilhada oposta ao profilo da espigueta e precedendo o mesmo.

Brácteas involucrais - brácteas geralmente foliáceas, podendo ser glumiformes, situadas junto à base da inflorescência, de número variável, ausente em poucos gêneros, como Eleocharis.

Caudex - estrutura lenhosa, semelhante a um rizoma, porém com crescimento vertical.

Cerdas perigoniais - estruturas geralmente cilíndricas, escabras ou pilosas, localizadas abaixo do androceu e do gineceu. Frequentemente permanecem presas à base do fruto maduro.

Colmo - eixo que sustenta a inflorescência, com as folhas concentradas na base ou distribuídas ao longo do mesmo. Alguns autores utilizam o termo escapo.

Contralígula - pequena estrutura que às vezes se forma no ápice da bainha foliar, no ponto de união das margens, do lado oposto à lâmina foliar.

Escamas - estruturas glumiformes posicionadas na base do aquênio.

Espiga - inflorescência com as espiguetas sésseis.

Espigueta - conjunto de flores protegidas pelas glumas, dispostas sobre a ráquila. Pode estar reduzida a uma gluma e uma flor.

Estilopódio - estrutura presente no ápice do aquênio de alguns gêneros de ciperáceas, resultante do desenvolvimento, em maior ou menor grau, da base do estilete que persiste sobre o ápice do fruto após a queda do restante do estilete e dos estigmas, na maturação. Ex.: Rhynchospora. Alguns autores utilizam o termo rostro para esta estrutura.

Flor - estrutura de reprodução sexual, composta por androceu e gineceu (se bissexuada) ou só um dos dois verticilos (se unissexuada), e de peças perigoniais (cerdas ou escamas) que representam o perigônio reduzido, ou perigônio ausente.

Gluma - bráctea escamiforme que porta uma flor em sua axila, ocasionalmente vazia e estéril.

Hipogínio cupuliforme - estrutura membranosa ou córnea, presente em alguns gêneros de Cyperaceae (ex.: Scleria), que se desenvolve na base do fruto envolvendo-o parcialmente. A origem do hipogínio, se oriundo do receptáculo ou de resquícios do perigônio, necessita de maiores esclarecimentos.

Inflorescência capitada - semelhante a um capítulo, constituída por pequenas espiguetas sésseis sobre um receptáculo aplanado.

Inflorescência monocéfala - estrutura única no ápice do colmo, geralmente globosa ou hemisférica, formada por várias espiguetas sésseis. Paniculódio - inflorescência com o eixo central mais longo do que os ramos floríferos laterais. É referida por alguns autores como panícula, em Cyperaceae.

Perigônio - verticilo formado por cerdas perigoniais ou por estruturas escamiformes, ou ausente.

Utrículo - estrutura que envolve totalmente o aquênio, em alguns gêneros de Cyperaceae, como Carex. No gênero Trilepis esta estrutura pode ser membranosa a rígida, e difere de Carex principalmente pela sua forma estreito-oblonga, tendo sido denominada por Vitta (2002) de "frutificação (utrículo)". Esta estrutura também tem sido referida, por alguns autores, como perigínio, porém a origem da mesma não é clara. Desta forma, foi utilizado o termo "utrículo" no presente trabalho por ser de mais ampla aceitação.
} 